Rhode Island College

Digital Commons @ RIC

$11-21-2018$

\title{
Music Therapy for Preoperative Anxiety in Surgical Patients: An Integrative Review
}

Alexandra Deuel

Follow this and additional works at: https://digitalcommons.ric.edu/etd

\section{Recommended Citation}

Deuel, Alexandra, "Music Therapy for Preoperative Anxiety in Surgical Patients: An Integrative Review" (2018). Master's Theses, Dissertations, Graduate Research and Major Papers Overview. 286.

https://digitalcommons.ric.edu/etd/286

This Major Paper is brought to you for free and open access by the Master's Theses, Dissertations, Graduate Research and Major Papers at Digital Commons @ RIC. It has been accepted for inclusion in Master's Theses, Dissertations, Graduate Research and Major Papers Overview by an authorized administrator of Digital Commons @ RIC. For more information, please contact digitalcommons@ric.edu. 


\title{
MUSIC THERAPY FOR PREOPERATIVE
}

ANXIETY IN SURGICAL PATIENTS:

\section{AN INTEGRATIVE REVIEW}

by

\author{
Alexandra Deuel \\ A Major Paper Submitted in Partial Fulfillment \\ of the Requirements for the Degree of \\ Master of Science in Nursing \\ in \\ The School of Nursing \\ Rhode Island College \\ 2018
}




\begin{abstract}
This integrative review compared the use of music interventions on the effects of preoperative anxiety in surgical patients. Preoperative anxiety can have detrimental effects such as increased blood pressure, increased heart rate, increased cortisol levels, increased infection risk, and delayed wound healing. Anesthetic complications include autonomic fluctuations, increased anesthetic requirements, tightening of the jaw, and possible coughing on induction of anesthesia. A search was completed using electronic databases including CINAHL, PubMed, and Medline. The PRISMA flowchart was utilized to identify research that was included and excluded in the review, with a final total of 10 studies. Studies were critically appraised using Polit and Beck's analysis tables and illustrated in individual tables identifying key aspects of the study. Outcomes included anxiety levels, vital signs, patient satisfaction including positive and negative emotions, length of procedure, and amount of medications used intraoperatively. Findings showed an overall decrease in anxiety levels when patients were exposed to some type of music intervention. Music interventions, including both live and prerecorded music, have been shown to have a positive impact on anxiety levels. Overall, this integrative review supported the use of music interventions as a safe, low-cost technique to help ease anxiety of patients awaiting surgery.
\end{abstract}




\section{Table of Contents}

Background/Statement of the Problem .................................................................. 1

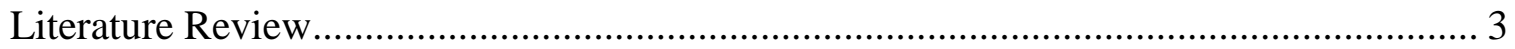

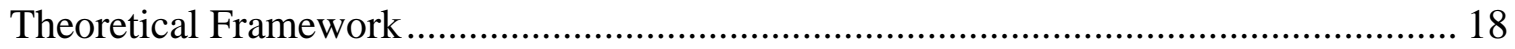

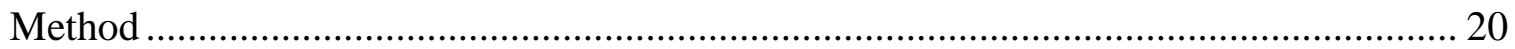

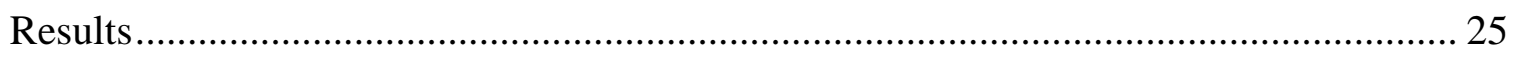

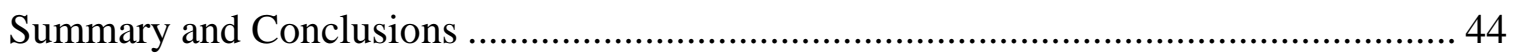

Recommendations and Implications for Advanced Nursing Practice ........................... 47

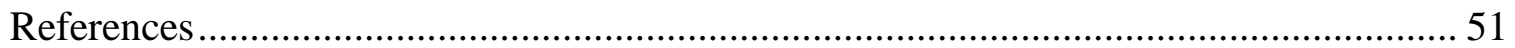

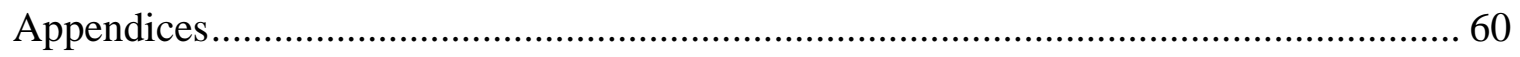


Music Therapy for Preoperative Anxiety in Surgical Patients: An Integrative Review

\section{Background/Statement of the Problem}

According to the National Institute of Mental Health (NIMH, 2005), anxiety affects $18 \%$ of the population, approximately 40 million people in the United States. Anxiety is the most common mental illness over the age of 18 and is regarded as a normal phenomenon that happens prior to surgery (NIMH). The National Alliance on Mental Illness (NAMI) estimates a yearly cost of disability accompanying severe mental illness to be as high as $\$ 193$ billion (2013). The Centers for Disease Control (CDC) estimates a lifetime prevalence of anxiety over $15 \%$ and is more prevalent in women than men (2018). Anxiety disorders are the most prevalent in any age group compared to other mental health disorders (American Psychiatric Association [APA], 2013).

The locus ceruleus of the brain has noradrenergic neurons and opioid receptors from which many potential emotional states such as panic, fear and anxiety are generated (Miller, 2015). These emotions are subjective and are manifested on an individual level as an increase in heart rate, blood pressure and/or respiratory rate. When physiologic changes become outside of normal limits, symptoms of anxiety are exhibited (Miller). Anxiety carries an increased risk for disability, and increasing premature mortality risk, especially in older adults (APA, 2013).

Anxiety is common prior to surgery and can affect patient outcomes. When patients are placed in unfamiliar environments such as the preoperative waiting area, they are exposed to medical professionals and are uncertain of the medical process, which tends to exaggerate anxiety levels. Individualized care is provided to meet specific patient needs, inclusive of type of procedure as well as comorbidities. Caring for patients with 
anxiety has traditionally involved pharmacological approaches, specifically benzodiazepines (Miller, 2015). Midazolam, a benzodiazepine, is the standard drug given in the preoperative period and an ideal anxiolytic (Nagelhout \& Plaus, 2014). The drug's rapid onset, short duration, and half-time make it appealing; however, unexpected respiratory depression and over-sedation are possible (Nagelhout \& Plaus).

Benzodiazepines work synergistically with opioids, but can significantly reduce arterial blood pressure and peripheral vascular resistance, as well as contributing to delayed recovery and discharge (Morgan \& Mikhail et al., 2013).

Music therapy has been proposed to reduce anxiety by exposing the patient to a form of music during the preoperative period (Bradt, Dileo, \& Shim, 2013). It has potential to be an inexpensive addition to help reduce anxiety in patients and offers a nonpharmacological/noninvasive holistic approach. Music therapy may be another tool to use when attempting to attain individualized care.

An integrative review was conducted to further investigate this issue and synthesize the available research. The purpose of this paper is to explore the impact of music therapy on preoperative anxiety in adult patients undergoing surgery. Evidence is needed to determine varying effects of music interventions and conclude whether anxiety levels were impacted as evidenced by physiological effects, such as decreased levels of heart rate, blood pressure, and/or respiratory rate, as well as possible improvement in emotional states in the preoperative adult patient.

Next, the review of literature will be presented. 


\section{Literature Review}

\section{Anxiety Definition and Characteristics.}

According to the CDC, anxiety disorders include panic disorder, generalized anxiety disorder, post-traumatic stress disorder, specific phobias, and separation anxiety disorder (2018). In aggregate, they are considered the most common class of mental illnesses among the general population (CDC). The Diagnostic and Statistical Manual of Mental Disorders (DSM-5) describes anxiety as an emotional, normal response to fear without a clear threat accompanied by increased muscle tension and vigilance (2013). In patients with other psychiatric disorders, it may be hard to distinguish characteristics of anxiety and differentiate between diagnoses (APA, 2013). Worldwide, anxiety prevalence is one in thirteen people, or 7.3\% of the population (Coppard-Queensland, 2012). Variability factors influencing prevalence rate include age, gender, culture, socioeconomic status, and urbanicity (Baxter, Scott, Vos, \& Whiteford, 2012).

Anxiety presents in the form of worry, fear, or apprehension (Pritchard, 2009). Anxiety is affected by previous experiences and presence of coping mechanisms (Kindler, Harms, Inde-Scholl, \& Scheidegger, 2000). An individual's perception of the environment plays a vital role in anxiety development and varies considerably among individuals with a wide range of presenting symptoms (APA, 2013). Anxiety may be difficult to identify and distinguish from avoidance and fear, as these are both normal responses and coping mechanisms (Lenze, Wetherell, \& Andreescu, 2006). Symptoms range from mild to severe and are characterized by feelings of dread or fear with psychological, physical, cognitive and behavioral aspects (World Health Organization 
[WHO], 2016). Mild symptoms may be ambiguous and warrant a complete history and physical exam to rule out other potential differential diagnoses.

Emotional symptoms of anxiety include feelings of apprehension, tense, or jumpy, restlessness or irritability, anticipating the worse and increased awareness of signs of danger (NAMI, 2013). Physical symptoms include increased heart rate, shortness of breath, upset stomach, headaches, fatigue, insomnia, frequent urination, and/or frequent diarrhea (NAMI). Anxiety may present in the form of a brief episode, or may be unexpected and prolonged leading to a panic attack, a peak intensity of feelings of worry and/or fear, seen in other mental illnesses, not just anxiety (APA, 2013). Patients may be tempted to avoid certain situations to avoid panic attacks.

Anxiety disorders differ according to the DSM-5 based on type of objects and/or situation encountered or anticipated, giving rise to feelings of fear, anxiety, or avoidance behavior causing the brain to interpret and react to the perceived threat (APA, 2013). The disorders vary in terms of severity and chronicity (McGrandles \& Duffy, 2012). In generalized anxiety disorder (GAD), there are six descriptive characteristics, including restlessness or feeling on edge or keyed up, easily fatigued, difficulty concentrating or mind going blank, irritability, muscle tension, and/or sleep disturbances (APA, 2013). The official diagnostic criteria of the DSM-5 suggests that patients with GAD may have symptoms for six months; however other research on GAD suggests symptoms may fluctuate and this criterion may not always be present (Kavan, Elsasser, \& Barone, 2009).

It can be hard to distinguish manifestations of certain types of anxiety disorders; therefore, it is important to assess for certain triggers and/or situations that cause fear, as 
well as other associated feelings or thoughts (APA, 2013). A clear explanation and cognitive ideation of anxiety is extremely valuable to differentiate the type of anxiety disorder, as well as triggers that may precipitate onset (APA).

\section{Neurophysiology of Anxiety}

Anxiety is thought to arise from the amygdala-prefrontal circuit in the brain, where emotional responses are derived (APA, 2013). It is postulated that deficient control of the prefrontal area in the brain and/or hyper-responsiveness of the amygdala are responsible for anxiety manifestations (APA). It is thought that over time, the brain becomes biased in anxious patients and the response of anxiety symptoms are the same upon activation of the circuity (APA).

Several theoretical models exist to explain the etiology and neurophysiology behind anxiety. A common consensus among theories is that the dysregulation of worry and overactivation of certain brain areas are involved, in addition to potential genetic and environmental factors contributing to one's response to certain situations and/or objects (Locke, Kirst, N, \& Shultz, 2015). Potential environmental factors include traumatic events, such as abuse, violence and/or prolonged illness which may be linked to the development of anxiety (NAMI, 2013).

In older adults, anxiety may be associated with accelerated cognitive decline and result from several potential causes. When anxiety is present in later years of life, the hypothalamic-pituitary-adrenal axis is activated, which increases cortisol levels and affects prefrontal function producing anxiety induced-neurodegeneration (APA, 2013). 
According to the DSM-5, anxiety definitions are sometimes general and have unclear pathophysiologies and are far from having clear, evidenced-based explanations of categories based on underlying etiology of anxiety (APA, 2013). As mentioned

previously, careful evaluation and thorough review of systems to rule out potential differential diagnoses is essential.

\section{Impact of Anxiety}

Fear and anxiety may overlap as symptoms. Fear is more often associated with an overwhelming arousal of the sympathetic nervous system, giving rise to thoughts of immediate danger and plans of 'escape,' rather than the more somatic tendencies shown with anxiety (APA, 2013). When the brain transmits an emotional response, a fight or flight situation occurs, in which neurotransmitters bring the impulse to the sympathetic nervous system and produce increased heart rate and breathing rate (Harvard Health Publications, 2017). At the same time, blood flow is directed from the abdomen to the brain and produces intense emotions (Harvard Health Publications). This process is a positive outcome when the body is in crisis, but turns counterproductive when prolonged (Harvard Health Publications)

If high levels of anxiety are not treated, people are at risk for increased blood pressure, increased heart rate, increased cortisol levels, delayed wound healing rates and increased risk of infections leading to unwanted physiological manifestations (Scott, 2004). Prolonged anxiety has been shown to co-exist in patients with heart disease, chronic respiratory diseases, as well as gastrointestinal diseases (Harvard Health Publications, 2017). When the body reacts to anxiety, it is in the form of stress, activated 
by the hypothalamic-pituitary-adrenal axis and the autonomic nervous system causing increased concentrations of catecholamines and hormones (McCance \& Huether, 2006). Catecholamines and hormones act as triggering agents and appear as symptoms of anxiety (McCance \& Huether). It is of utmost importance to identify and treat symptoms of anxiety in a timely manner to help prevent unwanted complications.

Regardless of which type of anxiety disorder is present, anxiety is associated with impairment in mental health, social and role functioning, general health, pain, physical functioning and activities of daily living (Kavan, Elsasser, \& Barone, 2009). In general, a mental illness may impair daily functioning by altering mood, behaviors, and ability to think clearly; it is said to be more disabling than that of cancer or heart disease (CDC, 2013). Certain types of anxiety, specifically GAD, are associated with self-treatment of alcohol and/or drugs and suicidal ideation (Kavan et al., 2009).

\section{Anxiety Risk Factors}

In a study performed by Blanco et al. (2014) via a one-factor model using the National Epidemiologic Survey on Alcohol and Related Conditions (NESARC), a sample that was nationally representative of the adult population of the United States was recruited. The purpose of the study was to explore risk factors of anxiety disorders. A total of 34, 653 participants were included in the face-to-face interview and several risk factors were identified and compared to major depressive disorder (MDD). Diagnoses were made based on the DSM-IV criteria and statistical analysis was completed. Female gender, family history of MDD, disturbed family environment, childhood sexual abuse, low self-esteem and lower educational status were all potential factors related to 
increased risk in anxiety of all types, with the exception of obsessive compulsive disorder (Blanco et al.).

The DSM-5 included similar risk factors with the addition of single or divorced marital status, poor social support system, younger age, as well as white (APA, 2013). Increasing evidence supports that there are genetic links to anxiety and transmission of anxiety disorders (APA).

\section{Anxiety Measurement}

Several measurement tools have been used in the literature to assist health care providers in identifying and assessing anxiety. It is critical that the health care provider be adequately trained to recognize and interpret symptoms of anxiety so that sufficient treatment can be provided. When using any type of scale, it is important to be cognizant that patients may not recognize their symptoms and furthermore, providers may not identify symptoms, potentially lending symptoms to other diseases present (McGrandles \& Duffy, 2012). Examples of scales used in the literature include Global Anxiety-Visual Analog Scale (GA-VAS), the Hamilton Anxiety Rating Scale (HAM-A), and the StateTrait Anxiety Inventory for Adults (STAI).

The GA-VAS first introduced by Aitken in 1969, is a self-assessment tool using a 100mm horizontal line, with one end of the scale (generally the left) representing no anxiety, with the other end (generally the right) representing extreme anxiety. The patient then marks the line to estimate their current level of anxiety and distance can be measured and used for statistical analysis (William, Morlock \& Feltner, 2010). The scale is straightforward, simple to use and is known to be more effective when used over time, 
rather than at one specific snapshot in time (William et al.). According to a study done by William et al., reviewing the effectiveness of the scale using a double blinded, randomized, placebo controlled with lorazepam and paroxetine for treatment of GAD, the GA-VAS was used to assess reliability, validity, responsiveness, and utility of the scale (2010). The study took place at clinic visits and at home for four weeks. Results showed marginally adequate test-retest stability, validity correlation with HAM-A, and demonstrated reliability, validity and responsiveness in these settings only (William et al.).

The Hamilton Anxiety Rating Scale (HAM-A) was first developed in 1959 by M. Hamilton and consists of a 14 self-assessment questionnaire to measure the severity of presenting anxiety symptoms (Hamilton, 1959). The well-known interview scale uses a five-point Likert-type scale ranging from $0-4$, with a score of 0 representing symptoms not present, to a 4 representing symptoms are severe (Psychiatric Times, 2013). Scores $>17 / 56$ are associated with mild anxiety and scores $>25-30$ are considered moderate to severe anxiety (Thompson, 2015). The scale is most often used in patients with GAD (Psychiatric Times, 2013). This score is useful because it incorporates respiratory, gastrointestinal and cardiovascular symptoms that may be present in anxiety (McGrandles \& Duffy, 2012). A study that investigated Parkinson’s disease and anxiety, Kummer et al. found that the HAM-A resulted in a reliability score of 0.893 Cronbach alpha score, meaning it has good internal consistency in this setting assessing Parkinson’s disease patients for GAD (2010). A meta-analysis by Wan, Zhang, Tedeschi, \& Hackett showed a large body of data using the HAM-A across multiple trials and compared findings to show good reliability and validity (2006). One limitation of note is that the 
scale may not adequately discriminate between symptoms of anxiety and depression (Matza, Morlock, Sexton, Malley, \& Feltner, 2010).

Spielberger's State-Trait Anxiety Inventory (STAI) is an established and widely used instrument to measure anxiety developed by Charles Spielberger. The scale consists of a 40-item questionnaire using self-evaluation to assess for two types of anxiety; SAnxiety scale or state anxiety and T-Anxiety scale or trait anxiety with 20 questions pertaining to each section (Spielberger, 1966). State anxiety assesses current mental states and how the patient feels at the present time, whereas trait anxiety measures general feelings of anxiety (Julian, 2011). Participants using the scale are required to rate intensity of feelings using a 4-point Likert scale (Pittman \& Kridli, 2011). According to the APA, this scale can be used in clinical settings to diagnose anxiety and distinguish from depressive states (2017). The scale is simple to complete and takes about 10 minutes to complete (Quek, Low, Razack, Loh, \& Chua, 2004). In a study of 237 participants, the STAI scale was used to study reliability and validity of patients with and without lower urinary tract symptoms (Quek et al.). The study showed excellent internal consistency and a Cronbach’s alpha score of 0.86 showing high reliability. Validity was supported along with a high degree of sensitivity, as well as a high level of homogeneity (Quek et al.). A prospective randomized study of 200 patients undergoing spinal anesthesia referred to STAI as the 'gold standard' for measuring preoperative anxiety (Dias, Baliarsing, Barnwal, Mogal, \& Gujjar, 2016).

Regardless of the scale used, a thorough history and review of patient comorbidities should be considered as these could alter manifestations of anxiety. The STAI scale is the most commonly used with multiple variations and can differentiate 
between general state of anxiety or an acute state of anxiety, a factor that most other scales lack.

\section{Impact of Anxiety on Individuals in the Preoperative State}

According to Caumo et al., preoperative anxiety has links to independent and dependent risk factors (2001). Independent risk factors that are not directly correlated with anxiety include (a) history of cancer, (b) smoking, (c) female, (d) psychiatric disorders, (e) self-report of moderate to severe pain, (f) physical status, and (g) presence of formal education. Dependent risk factors for anxiety have been identified as (a) fear of the unknown, (b) separation from family and friends, (c) fear of death or disfigurement, (d) concern regarding safety and/or pain, (e) fear of losing independence/control, and (f) recovery time in the postoperative period (Caumo et al.). Cooke, Chaboyer, Schluter, and Hiratos acknowledged that waiting time in the preoperative period can play a role in developing anxiety and exacerbating symptoms (2005). It is through combination of these factors that a patient becomes more vulnerable to experience the daunting emotion of anxiety.

Anxiety may be prominent beginning from the time surgery was advised as a treatment option and can progress to the day of surgery. Preoperative anxiety is reported to affect about $60-80 \%$ of surgical patients (Nigussie, Belachew, \& Wolancho, 2014). Peripheral vasoconstriction is a physiological manifestation due to anxiety and stress, potentially making the placement of an intravenous catheter and/or obtaining blood specimens more difficult (Pritchard, 2009). In addition, delayed jaw relaxation, coughing during induction of anesthesia, autonomic fluctuations and increased anesthetic 
requirement have also been encountered (Nigussie et al., 2014). Other aspects of care that may be impacted include heightened senses, pain, depression symptoms, nausea and fatigue (Carr, Thomas, \& Wilson-Barnet, 2005; Montgomery \& Bovbjerg 2004; Pritchard, 2009). These issues are aspects of a patient's care that must be acknowledged in the preoperative period before surgery, to better suit positive patient outcomes.

\section{Music Therapy Defined}

According to Thaut, the concept of music is believed to stimulate perceptual responses, which may be related to emotional states and therefore impact stress and anxiety levels (1990). Regardless of the setting, auditory stimulation is hypothesized to occupy neurotransmitters, which may prevent extreme emotional states like anxiety (Thaut). Other authors have argued that music is a way of relaxing and calming the mind, which diverts attention to the music and creates a shift of focus. According to the American Music Therapy Association (AMTA), music is an outlet for expression of feelings and can facilitate motivation for patients (2017).

Music is an inexpensive intervention used in various settings in medicine to assist the needs of patients. There are different types of music interventions, specifically distinguished as music medicine and music therapy. Music medicine relates to prerecorded material administered by the health care professional and may be referred to as passive listening (Bradt et al., 2013). Music medicine is convenient and cheaper. Limitations of having only a specific set of music and genre may conflict with patient preference. Another limitation is the availability and access to headphones and maintaining infection control. 
Music therapy designates trained music therapists to implement the intervention and are considered members of the health care team (Bradt et al., 2013). As a member of the interdisciplinary team, a music therapist must follow a specific protocol during encounters (AMTA, 2017). There is more variability with music therapy, as the therapist comes with a set of skills which may include choice of instrument with or without use of voice, different cultural background, as well as other combinations that are tailored to specific needs allowing more variability among patients (Bradt et al., 2013). For example, for a patient hard of hearing the therapist may choose to use a different tone or style of music. Music therapy has a benefit of fostering therapeutic relationships to meet and express physical, emotional, cognitive, and social needs of patients and may even be seen as a form of communication (AMTA, 2017).

The formal definition of 'music therapy' is associated with the use of evidencebased, trained personal performing music interventions (AMTA, 2017). However, it is of note that this term is often used loosely in clinical situations and may be used interchangeably with music interventions and/or music medicine to describe all types of music the patient may be exposed to. For example, a nurse administering music via a CD player for calming purposes may be described in some literature as administering music therapy. In the studies reviewed for the literature review, there is no consensus as to how interventions are defined or implemented. For purposes of this paper, music therapy is defined as any form of music intervention, in any setting and with any modality of music.

\section{Effects of Music Interventions on Anxiety in General}

Music modalities may be used to help patients both emotionally and physiologically, contribute to less medications, decrease potential postoperative pain, and 
promote faster recovery times (Bradt et al., 2013). Music therapy is postulated to decrease cardiovascular variability and the nociceptive effects from anxiety (Bradt et al.). Music can be used a stress management technique, with the benefit of having no side effects and can be used alone or in combination with other anxiety relieving techniques (Miller, 2015).

A systematic review and meta-analysis was done to investigate behavioral and psychological symptoms, as well as cognitive function and activities of daily living, in dementia patients using music therapy (Ueda, Sukukamo, Sato, \& Izumi, 2013). Music therapy had a moderate effect on anxiety, with a confidence interval (CI) of 95\% and p value of 0.002 . When music therapy was used for a duration greater than three months, the study showed large effects on anxiety, with a CI of 95\% and a p value of 0.02 (Ueda et al.).

A randomized controlled trial investigating the use of music therapy on intensive care unit (ICU) patients on mechanical ventilation examined anxiety levels using cortisol blood levels, heart rate, blood pressure, as well as subjective questionnaires. The study recruited 85 patients admitted to the ICU for greater than 24 hours and on a mechanical ventilator, randomly assigned to music interventions $(n=41)$ or the control group $(n=44)$. Results showed the music group to have significantly lower $(\mathrm{p}<0.02)$ anxiety levels on posttest measures as compared to the control group, with the exception to diastolic blood pressure (Lee et al., 2017a).

Another randomized controlled trial was done to explore effects of music on anxiety levels and physiological responses of surgical patients receiving spinal anesthesia (Lee et al., 2017b). The study was completed in the post anesthesia care unit (PACU) 
using 100 participants. The experimental group $(\mathrm{n}=50)$ was exposed to 30 minutes of music intervention and standard nursing care, while the control group $(n=50)$ received only standard routine nursing care. State trait anxiety inventory (STAI) scores were investigated, as well as heart rate, respiratory rate and blood pressure. Results showed a greater decrease in STAI scores in the experimental group as compared to the control group ( $\mathrm{p}<0.001$ ). In addition, heart rate, respiratory rate and blood pressure were all significantly decreased in the experimental group as compared to the control ( $\mathrm{p}<0.026$ (Lee et al., 2017b).

\section{Impact of Music on Anxiety in the Preoperative State}

Patients are often treated for preoperative anxiety with benzodiazepines, known to have side effects of respiratory depression and increased sedation. This is especially true for elderly, who may respond more dramatically due to aging effects on various body systems, including the kidneys and liver (Miller, 2015). Beyond the negative physiological issues caused by anxiety, the induction of anesthesia can be more complicated and the patient may experience a slower recovery time (Bradt et al. 2013). When patients are anxious, it is the responsibility of the practitioner to recognize and acknowledge the problem and treat it.

In a study of 239 patients, 168 patients in the preoperative period were identified to have high anxiety and described feelings of fear of death, fear of the unknown, fear of financial burden, fear of results of surgery, and/or fear of being awake during surgery (Nigussie et al., 2014). The study was performed on patients 15 years or older who were able to communicate and not taking antianxiety or antidepressants prior to surgery. A 
version of the STAI scale with 40 questions was used to analyze anxiety. Regardless of the cause of anxiety, it was found that time of surgery was a major factor in anxiety occurrence and the authors reported a 2.8 decrease in anxiety of patients having surgery in the afternoon compared to the first cases of the day. Overall, 70\% of participants reported significant anxiety and 65\% of participants did not receive any information about anxiety. The authors concluded that in general preoperative anxiety is high and that this issue must be addressed to help patients.

In a clinical controlled trial conducted by Yung, Chui-Kam, French, \& Chan, (2002), music interventions were explored related to the impact on preoperative anxiety in Chinese men undergoing a transurethral resection of the prostate (TURP). The study was completed with 30 patients, randomly divided into three groups with 10 in each group. One group was exposed to music, one group had a nurse present, while the last group was the control group. The Chinese version of STAI was used to measure anxiety and heart rate and blood pressure were recorded. Reduction in blood pressure was detected for all groups, as well as reduction in anxiety for the music group. Heart rate and anxiety showed no major changes in the nurse or control group (Yung et al.) Many limitations are noted in this study, including generalizability due to small sample size and specific procedures. Another limitation noted is control of extraneous variables that were not addressed. It is also of note that various nurse interactions may have taken place in the nurse group that could skew results.

With anxiety comes the potential need for increased medications, difficulty with induction and physiological changes (Bradt et al., 2013). Finding the right treatment for the patient, using the least invasive technique is optimal. Various studies have examined 
the impact of music therapy on preoperative anxiety in surgical patients and these will be reviewed in detail in the results section.

Next, the theoretical framework utilized for this integrative review will be discussed. 


\section{Theoretical Framework}

In 1966, Charles D. Spielberger took Raymond Cattell’s theory on anxiety and expanded on his work to describe anxiety as having two components, state anxiety and trait anxiety. Spielberger's theory of anxiety further defines these two concepts, from which an anxiety scale to model his work was developed in order to make the theory measurable.

\section{Spielberger's Theory of Anxiety}

Spielberger's theory of anxiety helps to guide the topic of investigating music therapy interventions to decrease preoperative anxiety in adult surgical patients. The State -Trait Anxiety Inventory (STAI) developed by Spielberger attempts to examine both state and trait anxiety in a 20 item self-report measurement tool. According to Spielberger, anxiety arises from a combination of internal and external stimuli, cognitive factors, as well as defense mechanisms (1966). The two concepts of anxiety exist as a state of anxiety or trait anxiety. State anxiety occurs when one is stimulated from internal or external factors, which impact responses due to perceptions of threat producing behaviors to fight off perceived anxiety as shown by actions by the human body (Spielberger, 1966). State anxiety is how one is able to cognitively encounter perceived threatening states and is used to assess anxiety at a specific time. This type of anxiety tends to change from time to time and vary in intensity, whereas trait anxiety often is a continual pattern more attributable to a personality trait (Caumo et al., 2001). Trait anxiety is the learned action of previous state anxiety which may predispose the individual to encounter future states of anxiety. This is often used to measure anxiety as a general feeling rather than specific occurrence (Spielberger, 1966). 
In terms of external criticism, Spielberger's theory of anxiety is reflective of reality convergence and contributes to real life situations of patients' experiences with anxiety, such as in the setting just prior to surgical procedures (Julian, 2011). This theory is useful, along with the anxiety scale (STAI), which has shown to be both a valid and reliable tool in several studies. The theory of anxiety is significant and addresses essential issues, which further contribute to knowledge development of the overall research. This theory can relate to multiple disciplines, not just the nursing profession. The scope of the theory is relatively broad but is narrowed down with the use of the STAI tool to measure anxiety.

Next, the methods section will be presented and discussed. 


\section{Method}

\section{Purpose}

The purpose of this integrative review was to explore the impact of music therapy on preoperative anxiety in adult patients undergoing surgery.

\section{Design}

An integrative review was chosen to synthesize a wide array of diverse methodologies.

\section{Inclusion/Exclusion Criteria}

Inclusion criteria for this review included: (a) age greater or equal to 18; (b) surgical patients-inpatient, outpatient, emergency or non-emergency, major and minor surgeries; (c) the preoperative setting; (d) studies that measured anxiety by psychological and physiological factors; (e) quantitative and/or qualitative designs; (f) includes a form of music therapy as strategy to reduce anxiety; and (g) studies written in English.

Exclusion criteria included: (a) settings other than preoperative setting, unless preoperative was separately acknowledged; (b) ages less than 18; (c) strategies to decrease anxiety that does not include music therapy; (d) articles in foreign languages; (e) literature over 10 years; and (f) studies with less than 20 subjects. No limits on gender or ethnicity were included. 


\section{Search Strategy}

The search strategies used were through electronic searches from PubMed, Medline, and CINAHL databases to retrieve articles. The ancestry approach was used with multiple articles to expand the search. The following key words were used to search for articles: music; preoperative anxiety; anxiety; anxiety measures; music interventions; and music therapy. An initial generalized search using keyword 'music therapy' yielded 5334 articles on Medline, 5005 located within CINAHL, and 5334 on PubMed. The search was narrowed using an additional keyword "preoperative anxiety". The search was significantly reduced to 73 articles within Medline, 65 within CINAHL, and 73 within PubMed. A final advanced search included English language, age criteria, and human subjects generated 7 articles from CINAHL, 14 articles by PubMed, and 6 by Medline. Next, any duplicate studies from the three search hosts were removed and articles were screened again for eligibility. If any full-text articles were removed, reasons for removal are noted and provided to the reader via a flowchart (Figure 1). The end result was a final number of 10 articles included in the integrative review. 


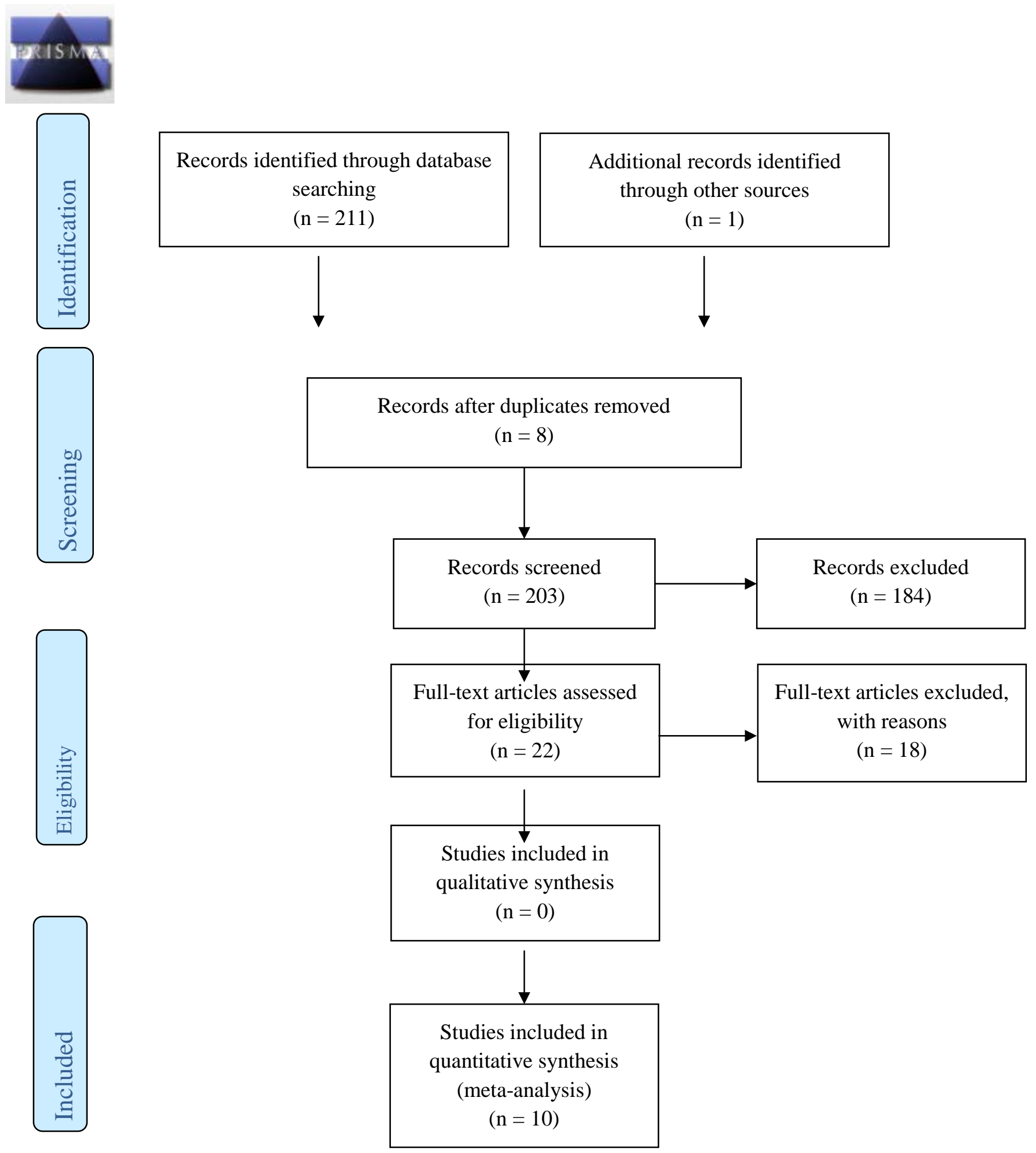

Figure 1. PRISMA Flow Diagram. This figure illustrates the PRISMA statements flow diagram used for the search strategy performed when conducting an integrative review to evaluate eligibility of studies included. 


\section{Data Collection Plan}

Each of the articles were scanned and read to meet the inclusion and exclusion criteria. If articles did not meet the criteria, they were not included in the review and are recorded as such. Whittemore and Knafl's article, The Integrative Review: Updated Methodology, defined strategies of methodologies specific to integrative reviews in five succinct stages (2005). The first stage was problem identification where the concept, target population, problem and clarity of purpose was established. The next stage was literature search stage where keywords, search strategy, and databases were identified. The data evaluation included a grading scale for quality assessment. The next stage was data analysis where data reduction, display, comparison of data, conclusions, verification, and generating generalized ideas was completed (Whittemore \& Knafl). The last stage was the presentation phase where a visual presentation was created and disseminated to a specific population for a purpose.

\section{Critical Appraisal}

Polit and Beck’s Guide to an Overall Critique of Qualitative and Quantitative Research Report (2017) was used to critically evaluate articles included in the integrative review. With this method, articles can be evaluated and appraised quantitatively and qualitatively to ensure a wide array of studies. To critique a quantitative article, several questions were used as a guide to evaluate articles and included title, abstract, introduction, method, discussion and general issues about the article. Within the introduction evaluation, the statement of purpose was investigated, hypotheses or research questions, literature review, and theoretical framework. The method section was appraised by investigating protection of human rights, research design, population and 
sample, data collection and measurement methods, procedures such as interventions, data analysis, and findings. Within the discussion section, interpretation of findings and implications/recommendations were further examined. Lastly, general issues regarding presentation, research credibility and summary assessment were explored.

In addition, Polit and Beck’s critique (2017) included an evaluation of a literature review. The critique questioned if the review was thorough, recent, peer-reviewed and based on primary sources. Did the review critically appraise and compare key studies? Did the review use appropriate language and objective? Did the author use paraphrases or quotes from original sources? Was the review part of a research report for a new study or support the need for a new study? Lastly, did the review identify gaps in the literature, was it well organized and were the development of ideas clear?

Next, the results section will be discussed. 


\section{Results}

Results for this integrative review are presented alphabetically by the first author's last name. Appendix A includes tables of critiques of quantitative studies and literature reviews included in the integrative review. Appendix B contains results with data from each study included in the review; for literature reviews, key findings are summarized.

\section{Critique of the Literature}

Arslan, Ozer, and Ozyurt (2008; Appendix A-1) conducted a quasi-experimental design using randomized controlled sampling of Turkish men undergoing urogenital surgery investigated the effects of music therapy on preoperative anxiety during 2007. The data were collected from a urology clinic in Aziziye Research Hospital, Suleyman Demirel Medical Centre and Ataturk University. The authors provided a clear statement of purpose, hypothesis and a thorough literature review. The method had a well thought out research design and included randomization of participants. The participants were divided into two groups; either routine preoperative care (control group) or exposed to music of choice for 30 minutes (experimental group). The sample size was well described and based off of a power analysis. The sample size was small and qualified as a limitation of the study. Other biases noted were selection bias of only men included in the study. Inclusion and exclusion criteria was adequately defined. A data collection questionnaire included information on demographics (marital status, education, age and reason for surgery) and State Trait Anxiety Inventory (STAI) was collected. The method in which data were reviewed was not explained and it is unknown if one or all of the authors reviewed the data and how they minimized biases. The method of data analysis was 
addressed adequately, and findings were displayed in three tables. Statistical significance was defined as $\mathrm{p}<0.05$.

The authors reported a decrease in anxiety score average in the experimental group compared to the control group that was statistically significant $\mathrm{p}<0.001$ (Appendix B-1). Mean score before therapy were 39.59 and after therapy were 33.68 for the experimental group. For the control group, mean scores before therapy were 42.25 and after therapy 44.43. Results were not generalizable to all male patients undergoing urogenital surgery or to all Turkish patients due to small sample size from one geographical area of Turkey. The results of the study suggested that listening to preferred music was an effective tool to reduce preoperative anxiety, however in order to generalize results a larger sample size is needed. The discussion section incorporated past research, addressed implications of the findings, and recommended that music be incorporated into future patient encounters.

Dong and Li (2012; Appendix A-2) conducted a present prospective, randomized control study with a quantitative approach to evaluate the effect of music played preoperatively in women undergoing elective cesarean delivery during 2011. The data were collected from Shengjing Hospital. The authors provided a clear statement of purpose and a brief literature review but built a strong basis for a new study. There were no hypotheses or conceptual frameworks provided. The method was well thought out research design and included randomization via a computer-generated number table to assign participants. The participants were randomized into a study group, where the participants listened to music for 30 minutes before surgery and a control group. The sample size was described in sufficient detail and a power analysis was used to calculate 
sample size needed. The sample size was small $(\mathrm{N}=60)$ and may have contributed to bias. Blinding was not used and could also have contribute to bias. Inclusion criteria were adequately defined. The outcome measures were visual analog scale (VAS) for pain, Zung Self-Rating Anxiety Scale (SAS), and heart rate variability (HRV) via a Holter monitor to look at low-frequency power (LF) and high-frequency power (HF). The method in which data were received was not explained and it is unknown if one or all of the authors reviewed the data. The method of data analysis was addressed adequately, and findings were summarized in two tables. Statistical significance was set at $\mathrm{p}<0.05$.

The results of the study are summarized in Appendix B-2. Results showed that music can reduce preoperative anxiety, especially in cesarean delivery, and it can augment effects of anesthesia and maintain hemodynamic stability. The mean LF and LF/HF values were significantly lower and mean HF significantly higher after music therapy ( $\mathrm{p}<0.05$ for all). Overall differences in values for LF showed intervention group differences of $119.50 \pm 201.58$ and in the control group $-15.86 \pm 71.29$. The HF showed differences in the intervention group of $-113.00 \pm 130.62$ and control group $14.45 \pm$ 51.40. LF/HF showed intervention group differences of $0.69 \pm 0.51$ within the intervention group and control group $0.00 \pm 0.50$. The mean SAS score was significantly less $(\mathrm{p}<0.05)$ and unchanged in the control group. Difference in values for the intervention group in terms of VAS scores were $7.20 \pm 2.09$ and $0.03 \pm 3.50$ for the control group. The changes between groups showed mean SAS score and HRV values were significantly greater than control $(\mathrm{p}<0.01)$. The authors did not attempt to generalize to areas outside of women undergoing cesarean delivery. The discussion section incorporated past research, addressed implications of the findings, and recommended that 
music can reduce preoperative anxiety and ease tension in surgery. Specifically, in cesarean deliveries, music can augment effects of anesthesia and maintain hemodynamics, which can in turn decrease the rate of potential complications and improve overall outcomes of patients. A limitation of the study included the possibility of anesthetic drugs affecting the sympathetic nervous system and thereby affecting HRV values.

Ertuğ, Ulusoylu, Bal, and Özgür (2017; Appendix A-3) conducted a repeatedmeasures randomized controlled trial to determine and compare the effectiveness of nature sounds and relaxation exercises for reducing preoperative anxiety. The data were collected from a hospital in Ankara, Turkey. The authors provided a clear statement of purpose, hypothesis, and a thorough literature review that built a strong basis for a new study. The hypothesis stated that patients who are exposed to nature sounds or use relaxation techniques will have lower anxiety levels than patients resting silently during the preoperative period. The method included a well thought out research design and randomization of participants was done via a permuted block randomization with sealed envelopes to assign the three groups. To avoid bias, a person not included in the study arranged the envelopes. The three groups included a nature sound group, a relaxation exercise group and a control group. The sample size was described in sufficient detail. A pilot study was done to determine an adequate sample size using a power analysis. A flowchart was utilized to show participant enrollment, refusal, inclusion criteria and total number analyzed in each group. The study was not blinded, and this may have contributed to bias. In addition, participants were exposed to relatives for 30 minutes between the second and third measurement and this may have influenced anxiety levels. 
The outcomes were measured using State Anxiety Inventory (SAI) and Visual Analog Scale (VAS). The method in which data were reviewed and by whom was clearly outlined. The method of data analysis was addressed adequately, and findings were displayed in two tables and two figures in which VAS and SAI scores were plotted over time.

Findings are summarized in Appendix B-3. A p value of $<0.005$ was accepted as statistically significant. The results showed that nature sounds and relaxation exercises were found to reduce preoperative anxiety in the intervention groups compared to the control group. A p value of $<0.005$ was accepted as statistically significant. VAS scores after the 30-minute intervention were lower in nature sounds groups and relaxation exercises group than the control group $(3.10 \pm 1.68,3.28 \pm 1.80,5.44 \pm 2.66 ; \mathrm{p}=0.011)$. Post hoc analysis showed that the control group have higher VAS scores $(\mathrm{p}<0.016)$. According to a Pearson correlation analysis, a strong correlation was found between VAS and SAI scores. The authors did not attempt to generalize results. The discussion section incorporated past research, addressed implications of findings, and recommended music as an aid in reducing preoperative anxiety in patients getting general anesthesia. The authors reasonably identified the need for further study recommendations including long period of sessions conducted and objective measurements utilized.

Ghetti et al. (2013; Appendix A-4) conducted a randomized, pre- and post-test experimental design evaluating the use of music therapy, specifically using an emotionalapproach coping on preprocedural anxiety in patients undergoing cardiac catheterization. The data were collected from an outpatient cardiovascular treatment and recovery unit from a Midwestern teaching hospital. The authors provided a clear statement of purpose 
and thorough and succinct literature review. No hypothesis was included in the study. The method had a well thought out research design and included randomization of participants. Informed consent was obtained, and protection of human rights was maintained. The sample size was small $(\mathrm{N}=37)$ and qualified as a limitation of the study. Other biases included a sole researcher, as well as participants and researcher were not blinded. However, the nurses and the interventional cardiologist were blinded. Inclusion criteria were adequately defined. It is of note that only $72 \%$ of participants who signed informed consent and met inclusion criteria completed the entire study. The reason for withdrawal was due to patient needing procedure before completing study measures, receiving medications before the end of the procedure or canceled due to lab results. Participants were divided randomly into three groups: one group with music therapy and emotional-approach coping; an emotional-approach coping group; and a control group with standard care. The researcher examined psychological, physiological and procedural variables to make comparisons between groups. Psychological variables included the Positive and Negative Affect Schedule (PANAS) to measure mood states. Physiological variables were measured using vital signs. Procedural variables included length of procedure in minutes, amount of benzodiazepine (Versed) in milligrams, and amount of analgesic (Fentanyl) required for the procedure in micrograms. The method of data analysis was addressed adequately, and findings were displayed in three tables and figures.

Findings are summarized in Appendix B-4. Statistical significance was set at $\alpha=0.05$, which is consistent with the music therapy literature. The results of the study showed that music therapy (MT) with emotional-approach coping (EAC) group led to 
improved positive affect states and the EAC group and control group did not. Positive affect results in the MT/EAC group showed pre (28.54) and post (33.46); the EAC group showed pre (31.48) and post (32.29); and the control group showed pre (30.60) and post (30.50). In terms of negative effects, the MT/EAC group showed pre (15.62) and post (12.69); the EAC group showed pre (19.93) and post (17.86); the control group showed pre (14.30) and post (14.30). All groups showed a significant decrease in negative affect. The MT/EAC group showed a statistically significant increase in systolic blood pressure (129.36 MT/EAC group compared to 128.67 in the control group; $\mathrm{p}=0.012$ ), but not clinically significance as this may be due to active engagement in the activity of music making. In addition, results showed the MT/EAC group to have the shortest procedure lengths and least amount of benzodiazepines required, but not statistically significant $(p=0.285)$. The results of the study were not generalizable outside patients awaiting cardiac catherization and overtly stately this in the study. The discussion section incorporated past research and addressed implications of findings and recommended using a bigger sample size, longer treatment times, as well as including inpatient and outpatient populations.

Kovac (2014; Appendix A-5) conducted a literature review investigating music interventions for the treatment of preoperative anxiety. The review was thorough and included all major studies related to the topic. Recent research was included and relative to the publication date. Appropriate studies from other disciplines were included. Mostly primary sources were used and from peer-reviewed sources. The review was primarily a summary of existing work and adequately compared key studies and brought concepts together. Gaps in the current literature were identified in the review. Overall, the review 
was organized and the development of ideas to the reader was adequately understood. There was appropriate language and the review was objective, with a substantial amount of citing from original sources incorporated to report results of previous work done on the topic. Overall, the literature review drew reasonable conclusions about practice implications regarding music therapy and effectiveness on preoperative anxiety.

Kushnir, Friedman, Ehrenfeld, and Kushnir (2012; Appendix A-6) conducted a pre- and posttest experimental design with random assignment to assess the effects of listening to selected music while waiting for a cesarean section on emotional reactions, cognitive appraisal of the threat of surgery, and stress-related physiological reactions. The data were collected from a large regional hospital in Israel. The authors provided a clear statement of purpose, hypothesis, and a strong literature review. The method had a well thought out research design and included randomization of participants. However, researchers themselves were not blinded to randomization of subjects and may contribute to bias. Participants were divided into two groups, an experimental group, exposed to preferred music for 40 minutes and a control group with standard care. Other procedures with a potential for bias included a nonblinded technique. The sample size was small $(\mathrm{N}=60)$ and was not based off of a power analysis. Inclusion and exclusion criteria were briefly described. Data collection included vital signs, a Mood State Scale, and a Perceived Threat of Surgery Scale, which are both reported to be reliable. The method in which data was reviewed was not explained and it is unknown if one or all of the authors reviewed the data and how they minimized biases. The method of data analysis was addressed adequately and findings were displayed in two tables and one figure showing subjective measures. 
Findings are summarized in Appendix B-6. Simple effects analyses showed that after 40 minutes of music in the experimental group ( $4.10 \pm 0.85)$, positive emotions were higher than the control group $(3.83 \pm 1.05)$, in addition to lower negative emotions (experimental group $3.49 \pm 0.86$; control group $4.06 \pm 0.83$ ) and perceived threat (experimental group $3.19 \pm 0.65$; control group $3.27 \pm 0.73$ ) compared to baseline values ( $<<0.0001$ for all subjective measures). Significance regarding systolic blood pressure (SBP) (experimental group $122.07 \pm 12.35$; control group $124.03 \pm 13.30 ; \mathrm{p}<0.05$ ), diastolic blood pressure (DBP) (experimental group 74.11 \pm 9.49; control group $77.38 \pm$ 20.04; $\mathrm{p}<0.01)$ and respiratory rate $(\mathrm{RR})$ (experimental group $21.75 \pm 2.15$; control group $21.87 \pm 2.38 ; \mathrm{p}<0.0001)$. Diastolic blood pressure and respiratory rate remained unchanged compared to baseline in the experimental group. However, in the control group, diastolic blood pressure and respiratory rate were higher after 40 minutes compared to baseline. The discussion section incorporated past research and addressed implications of findings and recommended music be incorporated into patient encounters prior to surgery. Results were not able to be generalized outside of women undergoing cesarean sections due to small sample size.

Labrague and McEnroe-Petitte (2016; Appendix A-7) conducted a pre- and posttest experimental design study to determine the influence of music on anxiety levels and the physiologic parameters in women undergoing gynecologic surgery. The data were collected from a 150-bed government hospital in Samar Province, Philippines. The authors provided a clear statement of purpose and a thorough literature review with synthesis of evidence using past literature relevant to the topic. The method had a well thought out research design, but did not include randomization of participants, which may 
have contributed to bias. The sample size was well described and purposive sampling was utilized. The sample size was adequate $(\mathrm{N}=97)$. Inclusion criteria were clearly stated. Data collection measures included vital signs and State Trait Anxiety Inventory (STAI). Participants were placed in either a control group with standard care or a music group with three different types of prerecorded music to choose from. The method in which data was reviewed was not explained and it is unknown if one or both authors reviewed the data and how they minimized bias. The method of data analysis was clearly described and findings were summarized in three tables.

Findings are summarized in Appendix B-7. Statistical significance was set at $\mathrm{p}<0.05$. The results showed decreases in STAI scores (before $40.75 \pm 1.97$; after $36.43 \pm$ 1.86; $t=0.61$ ), systolic blood pressure (before $127.60 \pm 5.20$; after $123.04 \pm 4.25$; $t=7.99$ ), diastolic blood pressure (before $75.93 \pm 5.15$; after $73.81 \pm 4.91$; $t=4.16$ ) and pulse rate (before $75.39 \pm 4.87$; after $71.39 \pm 4.28$; $t=5.33$ ) for the experimental group. Overall, results showed women in the experimental group had lower STAI scores than the control group. Statistically significant increases in STAI scores were noted (before $41.18 \pm 2.16$; after $43.30 \pm 2.02 ; \mathrm{p}<0.05$ ) and pulse rate (before $74.82 \pm 4.35$; after $77.51 \pm 3.95$; $\mathrm{p}<0.05)$. Independent $\mathrm{t}$ test analyses showed the experimental group had lower STAI scores $(t=17.41 ; \mathrm{p}<0.05)$ than the control group. The discussion section incorporated past research and addressed implications of findings and recommended music be incorporated into patient encounters prior to surgery. Results were not able to be generalized outside of women undergoing gynecologic surgery.

Lee et al. (2011; Appendix A-8) conducted a three-group randomized controlled trial investigating the anxiety relieving effect of broadcast versus headphone music 
playing for patients before surgery during 2009. The data were collected from a teaching hospital in Taiwan. The authors provided a clear statement of purpose and a brief, succinct literature review. The method had a satisfactory research design and included randomization of participants. A random table was applied to divide numbers 1-30 into three groups to identify each day of the month as being assigned to one of the three groups. Participants were randomized to either a control group, a headphone group, or a broadcast group. The study lacked a pre- and post-test comparison, but to offset this a control group was added to act as a reference point. The study was designed to minimize bias and threats to internal validity. Blinding was not used and may have contributed to bias. The sample size was described in sufficient detail and based off of a power analysis. The sample size was large $(\mathrm{N}=167)$. Inclusion criteria were clearly identified. Data collection measures included Visual Analog Scale (VAS) and heart rate variability (HRV). The method in which data was reviewed was not explained and it is unknown if one or all of the authors reviewed the data and how they minimized bias. The method of data analysis was addressed adequately and findings were summarized in three tables.

Findings are summarized in Appendix B-8. Statistical significance was defined as $\mathrm{p}<0.05$. Results showed the mean anxiety level for the control group was significantly higher than the headphone and the broadcast group (5.1 $\pm 2.7 ; 4.4 \pm 1.6 ; \mathrm{p}<0.05)$. There was a significant difference in high frequency HR variability among the three groups (broadcast 42.5, headphone 42.9 and control 35.4; $<<0.01$ ). In addition, there was significance in the low frequency HR variability among the three groups (broadcast 54.8, headphone 57.1 and control 64.6; $\mathrm{p}<0.01$ ). The discussion section incorporated past research and addressed implications of findings and recommended that music has an 
immediate effect on anxiety reduction, however the retention of this is unclear. Results were able to be generalized to patients waiting for surgery. The findings of this study may provide a basis for future studies evaluating music therapy in different surgical procedures.

Ni et al. (2011; Appendix A-9) conducted a randomized controlled clinical trial to evaluate the effects of musical intervention on preoperative anxiety and vital signs in patients undergoing day surgery. The data were collected from an outpatient surgery department. The authors provided a clear statement of purpose, hypothesis and literature review. The method had a well thought out research design and included randomization of participants. The sample size was well described and not based off of a power analysis, but appeared to be adequate ( $\mathrm{N}=172)$. Randomization was used, but blinding was not and may have contributed to bias. The authors acknowledged that the use of an interviewer who administered the questionnaire may have introduced positive bias in scores. The design attempted to minimize bias by using objective outcome measures. Exclusion criteria were clearly defined. Participants were randomly divided into two groups, a music group with music delivered by earphones for 20 minutes and a control group without music. Data collection measures included State Trait Anxiety Inventory (STAI) and vital signs. Evidence that STAI was previously validated and exhibited high internal consistency (0.90-0.94) was provided. The method in which data was reviewed was not explained and it is unknown if one or all of the authors reviewed the data. The method of data analysis was addressed adequately and findings were displayed in two tables and one figure showing the flowchart of participants. 
Findings are summarized in Appendix B-9. Statistical significance was defined at $\mathrm{p}<0.05$. Significant decreases in STAI scores from baseline were seen in both groups $(\mathrm{p}<0.001)$. Statistical significance was also seen between the music and control groups in terms of STAI scores $(\mathrm{p}<0.001)$. STAI scores decreased my means of 5.83 and 1.72 in the music and control groups, respectively. Decreases in heart rate (music group -5.01 \pm 0.79; control group $-3.76 \pm 0.63$ ), systolic blood pressure (music group -7.72 \pm 1.16 ; control group $-12.89 \pm 1.16$ ) and diastolic blood pressure (music group $-4.26 \pm 0.87$; control group $-4.23 \pm 0.78$ ) were seen in both groups from baseline. The authors did not attempt to generalize and overtly stated findings were not generalizable to areas outside of day surgery. The discussion section incorporated past research and addressed implications of findings. The authors concluded that results of the study may indicate patients may benefit from listening to music before surgery as seen by reduced levels of anxiety and physiological indicators of anxiety.

Palmer, Lane, Mayo, Schluchter, and Leeming (2015; Appendix A-10) conducted a three-group randomized controlled trial to investigate the effect of live and recorded music therapy on anesthesia requirements, anxiety levels, recovery time, and patient satisfaction in women experiencing surgery for diagnosis or treatment of breast cancer. The data were collected from University Hospitals Case Medical Center in Cleveland, Ohio and University Hospitals Richmond Medical Center in Richmond Heights, Ohio. The authors provided a clear statement of purpose, hypotheses, and a brief, but good synthesis of evidence in the literature review. The sample size was well described, based off of a power analysis, and adequate $(\mathrm{N}=201)$. Eligibility requirements were described in sufficient detail. Purposive sampling was used. An online randomization module was 
used to ensure adequate concealment. The method had a well thought out research design and included randomization of participants. The design was set up to minimize bias and threats to internal validity. A permuted block randomization scheme was used to prevent personnel performing the study from guessing the next assignment. Participants were placed in one of three groups: a live music group; a prerecorded music group; or a usual care group without the use of music. Nurses in the study were not blinded and this may have contributed to bias. Data collection measures included the Global Anxiety-Visual Analog Scale (GA-VAS) scores, patient satisfaction, amount of Propofol required to reach a BIS of 70, vital signs, and time to discharge readiness. The method in which data was reviewed was not explained and it is unknown if one or all of the authors reviewed the data. The method of data analysis was addressed adequately and findings were summarized in three tables and two figures.

Findings are summarized in Appendix B-10. Statistical significance was defined as $\mathrm{p}<0.025$. Results showed that patient satisfaction overall was high with no difference between control and music groups or between recorded and live music groups independently. Both music groups showed a decrease in anxiety and both differed significantly from the control group $(-30.9 \pm 36.3$ and $-26.8 \pm 29.3 ; \mathrm{p}<0.001)$. There was no difference observed in GA-VAS scores between the music groups. Shorter discharge times were observed for the live music group when compared to the recorded music group (difference in 12 minutes; $\mathrm{CI}=-22.5$ to -2.2 ; $\mathrm{p}=0.018$ ). The authors stated that findings may provide a basis for future studies regarding evaluating music therapy in different surgical procedures. They did not attempt to generalize results and overtly stated they were not generalizable to areas outside of women undergoing breast surgery. The 
discussion section incorporated past research and addressed implications of findings and recommended the need for further studies regarding therapeutic values of music therapy, specifically in the perioperative setting.

\section{Cross-Study Analysis}

Appendix C illustrates findings across studies and illustrates a few recurring themes. The first theme is that preoperative music before surgery clearly influences anxiety levels in patients. Arslan et al. (2008), Dong and Li (2012), Ertug et al. (2012), Labrague and Mcenroe-Petitte (2014), Lee et al. (2011), Ni et al. (2011), and Palmer et al. (2015) all reported decreases in anxiety as measured by some type of anxiety scale. Four authors, Arslan et al. (2008), Ertug et al. (2017), Labrague and Mcenroe-Petitte (2014) and Ni et al. (2011) utilized the State Trait Anxiety Scale, which has been shown to be both reliable and valid in the literature. Even though these authors used the same State Trait Anxiety Scale, no same author used the same version of the scale, as it is translated into various languages. In addition, as with any scale used to measure anxiety, there can be uncontrollable factors such as family members present that may ultimately affect levels of anxiety. Ghetti (2013) and Kushnir et al. (2012) also reported decreases in anxiety, but measured anxiety using emotional scales examining positive and negative emotions. Lee et al. (2011) and Palmer et al. (2015) used visual analog scales to measure anxiety. With all the measurements used, the patient completed their own assessment, making them subjective. In addition, generally the use of blinding of the investigators and nurses was not utilized and may contribute to bias. It should also be noted that in the control groups there may have been an effect on scores due to presence of a caring professional, as noted by Ertug et al. (2017), Ghetti (2013), Ni et al. (2011) and Palmer et 
al. (2015). Ghetti noted that decreased wait times to receive care and the possible extra attention may have helped to decrease anxiety levels (2013). Ni et al. posed that use of an interviewer aware of the study may have introduced positive bias and may have impacted anxiety levels (2011). Retention of these anxiety reducing effects remain unknown and was only mentioned briefly in Dong and Li (2012) and Lee et al. (2011).

Another recurring theme was the type of music utilized in the study. Only three authors, Arslan et al. (2008), Kovac (2014), and Palmer et al. (2015), evaluated patients' anxiety using the patient's preference of type of music. Arslan et al. stated that not all patients are likely to prefer all of the same type of music and may differ in regard to age and culture (2008). Palmer et al. discussed how preferred music may stimulate the relaxation response by activating the parasympathetic part of the autonomic nervous system (2015). None of the studies allowed the use of patients’ own music. Three authors, Labrague and Mcenroe-Petitte (2014), Lee et al. (2011), and Ni et al. (2011), used headphones as a method of delivery. Labrague and Mcenroe-Petitte identified that using headphones versus speakers may cause different listening experiences, which may ultimately influence anxiety levels (2014). In addition, infection control was a concern with the use of headsets. Only three authors, Ghetti (2013), Kovac (2014) and Palmer et al. (2015), investigated live music on preoperative anxiety. As noted by Palmer et al., there is a logistical challenge of using live music in a fast-paced environment like the preoperative setting and this may not be a realistic option for everyday use (2015).

Six authors, Dong and Li (2012), Ghetti (2013), Kushnir et al. (2012), Labrague and Mcenroe-Petitte (2014), Lee et al. (2011) and Ni et al. (2011), utilized vital signs in addition to the anxiety measures. These secondary outcomes were adjuncts to 
determining if a patient was anxious as noted by the autonomic nervous system responses. However, changes in vital signs could also be attributed to increased arousal levels, activity level, and if applicable, related to the physical act of making music. In the study by Dong and Li, a decrease in LF value and $\mathrm{LF} / \mathrm{HF}$ ratio and rise of $\mathrm{HF}$ value indicated that there was reduction in sympathetic nervous system activation and therefore consistent with reduced anxiety levels, as seen by the reduced anxiety scores by the intervention group (2012). Lee et al. found the same results in terms of heart rate variability, showing that the low frequency and the low-to-high frequency LF/HF ratio of the broadcast and headphone groups were significantly lower in comparison to the control group (2011). In terms of physiological variables in the study done by Ghetti, no variation of respiratory rate, heart rate, or oxygen saturation were noted to be significant (2013). An increase in systolic blood pressure was noted, but this may have been related to the physical act of making music and not an accurate indicator of anxiety. The Kushnir et al. study showed a decrease in systolic blood pressure, diastolic blood pressure, and respiratory rate in the music intervention group compared to the control group, which was attributed to lower stress levels after listening to music at the 40-minute mark (2012). The same was true for the study done by Labrague and Mcenroe-Petitte, where results showed decreases in systolic blood pressure, diastolic blood pressure and pulse rate for the experimental group exposed to music (2014). Ni et al. found a decrease in heart rate, systolic blood pressure, and diastolic blood pressure in both groups (2011). However, results were explained to be attributed to "trait-related differences in sympathetic system response to stress, cultural expectations regarding the public display of emotion and previous experience with the stressor” (p.623). 
Generalizability of studies do not appear adequate due to small sample size found in several articles. Four authors, Arslan et al. (2008), Dong \& Li (2012), Ghetti (2013) and Kushnir et al. (2012), identified small sample size as a limitation. The samples sizes ranged from 37 to 207 participants, with an average number of 113 participants. However, of all of the articles, the highest number of participants was only 207. Six authors, Arslan et al. (2008), Dong \& Li (2012), Ghetti (2013), Kushnir et al. (2012), Labrague \& Mcenroe-Petitte (2014) and Palmer et al. (2015), conducted studies on specific types of surgeries, including urogenital surgery, cesarean delivery, cardiac catheterization, gynecologic surgery and breast surgery. Four of these authors, Arslan et al. (2008), Kushnir et al. (2012), Labrague \& Mcenroe-Petitte (2014) and Palmer et al. (2015), narrowed it down to gender specific surgeries. As noted by Kushnir et al., men may react differently to anxiety and thus, may result in different results in terms of anxiety levels (2012). In pregnant women, anxiety and psychosocial factors may lead to complications during pregnancy and birth; something men do not experience (Kushnir). In addition, responses to music may differ based on gender.

Finally, a lack of blinding was reported by four authors, Ertug et al. (2017), Ghetti (2013), Ni et al. (2011) and Palmer et al. (2015). All four authors attributed this to type of design utilized, all of which were randomized controlled trials. Ertug et al. stated blinding of both investigators and participants was not possible due to nature of the study and does not specify why (2017). However, due to treatment intervention options, it was obvious which group participants were in, i.e. silent room for control, nature sounds, or relaxation exercises. Ghetti explained that participants’ awareness of receiving or not receiving music intervention made it difficult to fully blind participants, which was conducted by 
the same researcher (2013). However, in this study, interventional cardiologists and nurses who administered medications during the cardiac catheterization were blinded to participation in the study. In the study conducted by $\mathrm{Ni}$ et al., the individuals collecting data were aware of who was in each group, as there was only one investigator in the study noted (2011). In addition, it was not noted whether or not participants in the control group had head phones on which would make blinding more difficult. In the study by Palmer et al., blinding was not possible due to the use of live music and the nature of the treatment options (2015). Five authors conducted randomized controlled trials and included Ertug et al. (2017), Ghetti (2013), Lee et al. (2011), Ni et al. (2011) and Palmer et al. (2015). One study conducted by Arslan et al. was a quasi-experimental design with randomized controlled sampling (2008). Another study was a present prospective randomized control study by Dong and Li (2012). There were two studies done with preposttest designs by Kushnir et al. (2012) and Labrague \& Mcenroe-Petitte (2014). Finally, a literature review was conducted by Kovac (2014).

Next, the summary and conclusions will be presented. 


\section{Summary and Conclusions}

An integrative review was conducted to examine the impact of music therapy on preoperative anxiety. Untreated anxiety may lead to increased blood pressure and heart rate, as well as increased cortisol levels and delayed wound healing with an increased risk of infection (Scott, 2004). Increased preoperative anxiety levels have been shown to result in delayed jaw relaxation, coughing during induction of anesthesia, autonomic fluctuations, and increased anesthetic requirement (Nigussie et al., 2014). The CINAHL, Medline, and PubMed databases were searched to find articles relevant to the proposed topic. A comprehensive literature review was conducted to highlight the impact of preoperative anxiety on patients undergoing surgery and anesthesia and the potential negative outcomes that may occur. Many articles found on preoperative anxiety were related to nurse influence, preoperative medications administered, and distraction techniques in general. In addition, the literature review defined the difference between music therapy and music intervention. Anxiety scales such as STAI and VAS were used, as well as physiological variables measured, such as vital signs and heart rate variability. In addition, procedural variables were measured in a few studies examining use of medications perioperatively and postoperatively and length of procedure time. The need for an integrative review was apparent upon review of the literature. Studies were screened for inclusion and exclusion criteria and only included if those were met. Results were recorded in the PRISMA flowchart (Figure 1).

Whittemore and Knafl's article, The Integrative Review: Updated Methodology, was utilized to identify strategies and methodologies specific to integrative reviews (2005). Polit and Beck’s guide to an overall critique of qualitative and quantitative 
research was used to critically evaluate the selected literature (2017). The critical appraisal of each article was completed in either a quantitative, qualitative, or literature review format and presented into a corresponding table.

There were a few limitations to this integrative review. Most of the studies had small sample sizes, limiting the ability to generalize. Another limitation was the unexpected potential for bias from influence of external factors such as family members. Family members could potentially have had positive or negative influences on patients and could have skewed overall outcomes of the included studies. The use of non-blinded nurses or investigators could also have skewed outcomes by influencing the type and amount of interaction with the subjects. The timing and type of music included in each study were different in each study, making it difficult to compare overall results to each other. Lastly, the use of only three databases to search for articles was a limitation.

The majority of the studies showed that use of preoperative music before surgery influenced anxiety levels in patients. Arslan et al. (2008), Dong and Li (2012), Ertug et al. (2012), Labrague and Mcenroe-Petitte (2014), Lee et al. (2011), Ni et al. (2011), and Palmer et al. (2015) all reported decreases in anxiety as measured by some type of anxiety scale. Ghetti (2013) and Kushnir et al. (2012) also reported decreases in anxiety, but measured anxiety indirectly using emotional scales examining positive and negative emotions. In terms of music intervention, only three authors, Arslan et al. (2008), Kovac (2014), and Palmer et al. (2015), evaluated patients’ anxiety using the patients’ preference for type of music and none of the studies allowed the use of patients' own music. Three authors, Labrague and Mcenroe-Petitte (2014), Lee et al. (2011), and Ni et al. (2011), used headphones as a method of delivery. Labrague \& Mcenroe-Petitte 
identified that using headphones versus speakers may cause different listening experiences, which may ultimately influence anxiety levels (2014). Lastly, only three authors, Ghetti (2013), Kovac (2014) and Palmer et al. (2015), investigated live music on preoperative anxiety, which was most likely related to cost and convenience in a preoperative setting.

In summary, the literature included in the integrative review supported music being utilized for anxiety in the preoperative setting. With anxiety comes the potential need for increased medications, difficulty with induction, and physiological changes (Bradt et al., 2013). Finding the right treatment for the patient, using the least invasive technique, is optimal. Use of music is a low-cost intervention with minimal risk to patients that should be further studied, implemented, and evaluated.

Recommendations and implications for advanced nursing practice will be discussed in the next section. 


\section{Recommendations and Implications for Advanced Nursing Practice}

Integrative reviews provide a synthesis of existing knowledge and give the reader the ability to then apply this information into practice using an evidence-based approach. The goal of a Certified Registered Nurse Anesthetist (CRNA) is to provide safe care to patients using standards of care, as well as incorporating evidence-based practice through up-to-date research to guide practice techniques. Preoperative anxiety is not always amenable to medications and may have a severe, negative impact on patient outcomes. When choosing an option to treat preoperative anxiety, a vigilant provider must use all of the tools available. Music intervention is one technique that has been shown to decrease anxiety in patients awaiting surgery.

Anxiety occurs frequently in the preoperative setting and may cause severe adverse effects like increased heart rate, blood pressure, cortisol levels, as well as delayed wound healing and increased anesthetic requirements. It is clear that for the advanced practice nurse, especially the CRNA, control of anxiety is extremely important to patients' overall well-being. The CRNA should utilize evidenced-based practices to minimize the effects of untreated anxiety. One way that anxiety may be minimized is with music intervention. It is an inexpensive and non-invasive technique that eliminates the potential side effects of medications needed to minimize anxiety levels just before surgery. Ten out of 10 of the articles included in this review demonstrated that the use of some type of music minimized preoperative anxiety to some degree. Using this practice may help to minimize or eliminate the potential side effects of medications such as benzodiazepines. Although it was not proven that music intervention worked better than anti-anxiety medications, it may benefit as an adjunct. Caution should be taken when 
using music intervention solely to treat severe anxiety, as this may not be adequate to manage anxiety.

Within the scope of CRNA practice, one patient is under his/her care at one time. There is sometimes a very narrow window of time to complete thorough preoperative assessments in-between cases and these may be completed by an anesthesiologist or a CRNA. At times, the act of initiating music intervention for preoperative anxiety may present a challenge. It is important for the CRNA to collaborate with the anesthesiologist and preoperative nurses as to what would be best for the patient experiencing preoperative anxiety. Anesthesiologists and preoperative nurses could be trained to set up and initiate a music intervention with the use of the music device, including headphones. A possible option is to have built in speakers into each of the rooms or a channel on the TV to plug headphones in or purchasing individual music devices and disposable headphones. The built-in speaker option may be costly and not suitable to all patients in the preoperative area. This may also impact patient care as a type of added distraction in an already busy environment.

In addition, teaching fellow CRNAs would be imperative. An evidence-based teaching presentation would help convey the importance and potential positive outcome of this intervention. Training skills would be minimal and would simply require operating a music device and retrieving the device and headphones. There are minimal ethical considerations in terms of music intervention. If patients become uncomfortable with the music at any time, simply shutting the device off would be adequate to meet patient anxiety level needs. 
From the articles reviewed, there have were no recommendations for policy change when it comes to using music interventions in the preoperative setting. However, CRNAs can collaborate with preoperative nurses and anesthesiologists to discuss and implement a policy for the institution that results in safety of patients and improved outcomes. To implement the policy of allowing music therapy into the preoperative area, the CRNA or chief CRNA may request to meet with management and administration of the hospital to discuss the possible options and propose the purchase of equipment that will be needed by emphasizing and encouraging the potential benefit to patients.

Future research may be done to assess the use of music interventions against the use of antianxiety medications, as well as evaluating the overall therapeutic value of music therapy. A study regarding music intervention compared to anti-anxiety relieving techniques including medications may help quantify overall significance of this practice. The studies assessed in this review all used similar methods of evaluation for anxiety, however they differed in the type of music and amount of time exposed to music. Further research may investigate the amount of time exposed to music intervention and the impact on preoperative anxiety. In addition, the method of evaluation when assessing anxiety may be subjective when using anxiety scales alone. Future studies may consider using blood levels of cortisol and other potential markers of anxiety in addition to vital signs and anxiety scales to serve as a more objective adjunct when evaluating anxiety. When lab results are used exclusively to measure anxiety, there may be other reasons for elevation, including sympathetic response to stress and should be used with caution.

This integrative review showed the benefits of using music as an aide in decreasing anxiety and this author has concluded that music is an acceptable intervention 
to be used in practice by the CRNA. With the use of this knowledge, advanced practice nurses may be better able to identify and treat preoperative anxiety in a variety of ways shown to have a significant effect on anxiety levels. Investigating these additional studies would help improve overall safety of patients and refine protocols already in place. 


\section{References}

Agarwal, A., Ranjan, R., Dhiraaj, S., Lakra, A., Kumar, M., \& Singh, U. (2005).

Acupressure for prevention of pre-operative anxiety: a prospective, randomised, placebo controlled study. Anaesthesia,60(10), 978-981. doi:10.1111/j.13652044.2005.04332.x

Aitken, RC. (1969). Measurement of feelings using visual analog scales. Proc R Soc Med, 62(10), 989-993.

American Music Therapy Association. (2017). What is music therapy. Retrieved July 12, 2017, from https://www.musictherapy.org/about/musictherapy/

American Psychiatric Association. (2013). Diagnostic and statistical manual of mental disorders; fifth edition. Arlington: American Psychiatric Association.

Arslan, S., Ozer, N., \& Ozyurt, F. (2008). Effect of music on preoperative anxiety in men undergoing urogenital surgery. Australian Journal of Advanced Nursing, 26(2), $46-54$

Baxter, A., Scott, K., Vos, T., \& Whiteford, H. (2012). Global prevalence of anxiety disorders: a systematic review and meta-regression. Psychological Medicine,43(05), 897-910. doi:10.1017/s003329171200147x

Blanco, C., Rubio, J., Wall, M., Wang, S., Jiu, CJ, \& Kendler, KS. (2014). Risk factors for anxiety disorders: common and specific effects in a national sample. Depression and Anxiety, 31(9), 756-764. doi:10.1002/da.22247 
Bradt, J., Dileo, C., \& Shim, M. (2013). Music interventions for preoperative anxiety. Cochrane Database of Systematic Reviews, Jun 6;(6):CD006908. doi: 10.1002/14651858.CD006908.pub2

Carr, EC., Nicky Thomas, J., Wilson-Barnet, J. (2005) Patient experiences of anxiety, depression and acute pain after surgery: a longitudinal perspective. International Journal of Nursing Studies. 42(5), 521-530

Caumo, W., Schmidt, AP., Schneider, CN., Bergmann, J., Iwamoto, CW., Bandeira, D., \& Ferreira, MB. (2001). Risks factors for preoperative anxiety in adults. Acta Anaesthesiologica Scandinavica 45(3), 298-307

Center for Disease Control. (2018). Children’s mental health. Retrieved from https://www.cdc.gov/childrensmentalhealth/data.html

Cooke, M., Chaboyer, W., Schluter, P., \& Hiratos, M. (2005). The effect of music on preoperative anxiety in day surgery. Journal of Advanced Nursing, 52(1), 47-55. doi:10.1111/j.1365-2648.2005.03563.x

Coppard-Queensland, V. (2012). Globally, 1 in 13 suffers from anxiety. Retrieved from http://www.futurity.org/globally-1-in-13-suffers-from-anxiety/

Daniel, E. (2016). Music used as anti-anxiety interventions for patients during outpatient procedures: A review of the literature. Complementary Therapies in Clinical Practice, 22, 21-23. Retrieved from http://www.ctcpjournal.com/article/S17443881(15)30020-7/pdf 
Dias, R., Baliarsing, L., Barnwal, N., Mogal, S., \& Gujjar, P. (2016). Role of preoperative multimedia video information in allaying anxiety related to spinal anaesthesia: A randomised controlled trial. Indian Journal of Anaesthesia,60(11), 843-847. doi:10.4103/0019-5049.193681

Dong, Y. \& Li, Y. (2012). Preoperative music intervention for patients undergoing cesarean delivery. International Journal of Gynecology \& Obstetrics,119(1), 8183. doi:10.1016/j.ijgo.2012.05.017

Ertuğ, N., Ulusoylu, Ö, Bal, A., \& Özgür, H. (2017). Comparison of the effectiveness of two different interventions to reduce preoperative anxiety: A randomized controlled study. Nursing \& Health Sciences,19(2), 250-256. doi:10.1111/nhs.12339

Ghetti, C. M. (2013). Effect of music therapy with emotional-approach coping on Preprocedural Anxiety in Cardiac Catheterization: A Randomized Controlled Trial. Journal of Music Therapy,50(2), 93-122. doi:10.1093/jmt/50.2.93

Grös, D. F., Antony, M. M., Simms, L. J., \& McCabe, R. E. (2007). Psychometric properties of the state-trait inventory for cognitive and Somatic anxiety (STICSA): comparison to the state-trait anxiety inventory (STAI). Psychological Assessment, 19(4), 369-381. doi:10.1037/1040-3590.19.4.369

Hamilton, M. (1959). The assessment of anxiety states by rating. British Journal of Medical Psychology, 32, 50-55 
Harvard Health Publications. (2017). Anxiety and physical illness. Retrieved from http://www.health.harvard.edu/staying-healthy/anxiety_and_physical_illness

Julian, L. J. (2011). Measures of anxiety. Arthritis Care \& Research, 63(11), 467-472 doi: 10.1002/acr.20561

Kavan, M. G., Elsasser, G. N., \& Barone, E. J. (2009). Generalized anxiety disorder: practical assessment and management. American Academy of Family Physicians, 79(9), 785-791

Kindler, C.H., Harms, CH., Inde-Scholl, T., \& Scheidegger, D. (2000). The visual analog scale allows effective measurement of preoperative anxiety and detection of patients’ anesthetic concerns. Anesthesia and Analgesia, 90(3), 706-712

Kovac, M. (2014). Music interventions for the treatment of preoperative anxiety. Journal of Consumer Health on the Internet,18(2), 193-201. doi:10.1080/15398285.2014.902282

Kummer, A., Cardoso, F., \& Teixeira, AL. (2010). Generalized anxiety disorder and the Hamilton Anxiety Rating Scale in Parkinson's disease. Arq Neuropsiquiatr, 68(4), 495- 501

Kushnir, J., Friedman, A., Ehrenfeld, M., \& Kushnir, T. (2012). Coping with preoperative anxiety in cesarean section: physiological, cognitive, and emotional effects of listening to favorite music. Retrieved from http://onlinelibrary.wiley.com/doi/10.1111/j.1523-536X.2012.00532.x/abstract 
Labrague, L. J. \& Mcenroe-Petitte, D. M. (2014). Influence of music on preoperative anxiety and physiologic parameters in women undergoing gynecologic surgery. Clinical Nursing Research,25(2), 157-173.

doi:10.1177/1054773814544168

Lee, CH. et al. (2017a). Effects of music intervention on state anxiety and physiological indices in patients undergoing mechanical ventilation in the intensive care unit. Biological Research for Nursing,19(2), 137-144. doi:10.1177/1099800416669601

Lee, WP., Wu, PY., Lee, MY., Ho, LH., \& Shih, WM. (2017b). Music listening alleviates anxiety and physiological responses in patients receiving spinal anesthesia. Complementary Therapies in Medicine,31, 8-13. doi:10.1016/j.ctim.2016.12.006

Lee, K. et al. (2011). Effectiveness of different music-playing devices for reducing preoperative anxiety: A clinical control study. International Journal of Nursing Studies,48(10), 1180-1187. doi:10.1016/j.ijnurstu.2011.04.001

Lenze, E., Wetherell, J., \& Andreescu, C. (2006). Clinical Manual of Geriatric Psychiatry: Anxiety Disorders. Retrieved from https://doiorg.ric.idm.oclc.org/10.1176/appi.books.9781615370016.mt07

Locke, A., Kirst, N., \& Shultz, C. (2015). Diagnosis and management of generalized anxiety disorder and panic disorder in adults. American Academy of Family Physicians,91(9), 617-624. Retrieved from http://www.aafp.org/afp/2015/0501/p617.html 
Matza, LS., Morlock, R., Sexton, C., Malley, K., \& Feltner, D. (2010). Identifying HAMA cutoffs for mild, moderate, and severe generalized anxiety disorder. International Journal of Methods in Psychiatric Research, 19(4), 223-232. Doi:10.1002/mpr.323

McCance, K. \& Huether, S. (2006). Pathophysiology: the biological basis for disease in adults and children, $5^{\text {th }}$ ed. Elsevier Mosby, St. Louis, MO

McGrandles, A., \& Duffy, T. (2012). Assessment and treatment of patients with anxiety. Nursing Standard, 26(35), 48-56

Miller, RD. (2015). Anesthesia for bariatric surgery. Miller's anesthesia (pp. 2200-2215). Philadelphia, PA: Elsevier Saunders

Montgomery, GH. \& Bovbjerg, DH. (2004) Pre-surgery distress and specific response expectancies predict post-surgery outcomes in surgery patients confronting breast cancer. Health Psychology. 23(4), 381-387

Morgan, G., Mikhail, M., \& et al. (2013). Morgan \& Mikhail's clinical anesthesiology. New York: McGraw-Hill

Nagelhout, J. J., \& Plaus, K. L. (2014). Nurse anesthesia. St. Louis, MO: Elsevier/Saunders.

National Alliance on Mental Illness. (2013). Mental illness facts and numbers. Retrieved from http://www.nami.org: http://www.nami.org/factsheets/mentalillness_factsheet.pdf 
National Institute of Mental Health. (2005). Any anxiety disorder. Retrieved from https://www.nimh.nih.gov/health/statistics/prevalence/any-anxiety-disorderamong-adults.shtml

Ni, CH., Tsai, WH., Lee, LM., Kao, CC., \& Chen, YC. (2011). Minimising preoperative anxiety with music for day surgery patients- a randomised clinical trial. Journal of Clinical Nursing, 21(5-6), 620-625. Doi:10.1111/j.1365-2702.2010.03466.x

Nigussie, S., Belachew, T., \& Wolancho, W. (2014). Predictors of preoperative anxiety among surgical patients in Jimma University Specialized Teaching Hospital, South Western Ethiopia. BMC Surgery,14(1). doi:10.1186/1471-2482-14-67

Palmer, J. B., Lane, D., Mayo, D., Schluchter, M., \& Leeming, R. (2015). Effects of music therapy on anesthesia requirements and anxiety in women undergoing ambulatory breast surgery for cancer diagnosis and treatment: a randomized controlled trial. Journal of Clinical Oncology,33(28), 3162-3168. doi:10.1200/jco.2014.59.6049

Pittman, S., \& Kridli, S. (2011). Music intervention and preoperative anxiety: An integrative review. International Nursing Review, 58(2), 157-163. doi:10.1111/j.1466-7657.2011.00888.x

Polit, D., \& Beck, C. T. (2017). Nursing research: Generating and assessing evidence for nursing practice (10th ed.). Philadelphia: Wolters Kluwer

Pritchard, M.J. (2009). Managing anxiety in the elective surgical patient. British Journal of Nursing, 18(7), 416-419 
Psychiatric Times. (2013). HAM-A Hamilton Anxiety Scale. Retrieved from http://www.psychiatrictimes.com: http://www.psychiatrictimes.com/clinicalscales-anxiety/clinical-scalesanxiety/ham-hamilton-anxiety-scale

Quek, KF., Low, WY., Razack, AH., Loh, CS., \& Chua, CB. (2004). Reliability and validity of the Spielberger State-Trait Anxiety Inventory (STAI) among urological patients: a Malaysian study. Retrieved from https://www.ncbi.nlm.nih.gov/pubmed/15559178

Scott, A. (2004). Managing anxiety in ICU patients: the role of pre-operative information provision. Nursing in Critical Care,9(2), 72-79. doi:10.1111/j.14785153.2004.00053.x

Spielberger, C. D. (1966). Anxiety and behavior. New York: Academic Press.

Thaut, M. (1990). Neuropsychological processes in music perception and their relevance in music therapy. Music Therapy in the Treatment of Adults with Mental Disorders. 3-32

Thompson, E. (2015). Hamilton Rating Scale for Anxiety (HAM-A). Occupational Medicine; Oxford Academic. Retrieved from https://academic.oup.com/occmed/article/65/7/601/1733495/Hamilton-RatingScale-for-Anxiety-HAM-A

Ueda, T., Sukukamo, Y., Sato, M., \& Izumi, S. (2013). Effects of music therapy on behavioral and psychological symptoms of dementia: a systematic review and 
meta-analysis. Ageing Research Reviews, 12(2), 628-641.

doi:10.1016/j.arr.2013.02.003

Wan G.J., Zhang H.F., Tedeschi M.A., \& Hackett D. (2006) Estimation of symptom-free days in generalized anxiety disorder. Current Medical Research and Opinion, 22, $587-591$

Whittemore, R., \& Knafl, K. (2005). The integrative review: updated methodology. Journal of Advanced Nursing, 52(5), 546-553. doi: 10.1111/j.13652648.2005.03621.x

William, V., Morlock, R., \& Feltner, D. (2010). Psychometric evaluation of a visual analog scale for the assessment of anxiety. Health \& Quality of Life Outcomes, 857. Doi:10.1186/1477-7525-8-57

World Health Organization. (2016). International Statistical Classification of Diseases and Related Health Problems 10th Revision (ICD-10). Retrieved July 30, 2017, from http://apps.who.int/classifications/icd10/

Yung, P., Chui-Kam, S., French, P., \& Chan, TM. (2002). A controlled trial of music and pre-operative anxiety in Chinese men undergoing transurethral resection of the prostate. Journal of Advanced Nursing,39(4), 352-359. doi:10.1046/j.13652648.2002.02296.x 


\section{Appendix A-1}

Arslan, S., Ozer, N., \& Ozyurt, F. (2008). Effect of music on preoperative anxiety in men undergoing urogenital surgery. Australian Journal of Advanced Nursing, 26(2), 46-54

\begin{tabular}{|c|c|c|}
\hline Aspect of the Report & Critiquing Questions & $\begin{array}{l}\text { Detailed Critiquing } \\
\text { Guidelines }\end{array}$ \\
\hline Title & $\begin{array}{l}\text { Is the title a good one, } \\
\text { succinctly suggesting key } \\
\text { variables and the study } \\
\text { population? }\end{array}$ & $\begin{array}{l}\text { The title clearly identified the } \\
\text { subject, location, and time } \\
\text { frame of the study. }\end{array}$ \\
\hline Abstract & $\begin{array}{l}\text { Did the abstract clearly } \\
\text { and concisely summarize } \\
\text { the main features of the } \\
\text { report (problem, methods, } \\
\text { results, conclusions)? }\end{array}$ & $\begin{array}{l}\text { The abstract thoroughly } \\
\text { summarized the main features } \\
\text { and includes objective, design, } \\
\text { settings, subjects, intervention, } \\
\text { main outcome measures, results } \\
\text { and conclusion. }\end{array}$ \\
\hline $\begin{array}{l}\text { Introduction } \\
\text { Statement of the } \\
\text { problem }\end{array}$ & $\begin{array}{l}\text { Was the problem stated } \\
\text { unambiguously, and was it } \\
\text { easy to identify? } \\
\text { - Is the problem statement } \\
\text { build a persuasive } \\
\text { argument for the new } \\
\text { study? } \\
\text { - Was there a good match } \\
\text { between the research } \\
\text { problem and the methods } \\
\text { used -that is, was a } \\
\text { quantitative approach } \\
\text { appropriate? }\end{array}$ & $\begin{array}{l}\text { The problem was easily } \\
\text { identified and clear to the } \\
\text { reader. } \\
\text { Introduction suggested benefits } \\
\text { of music and its anxiolytic } \\
\text { effects and builds an adequate } \\
\text { persuasive argument for a new } \\
\text { study. } \\
\text { The study's relevance to } \\
\text { nursing clinical practice was } \\
\text { clearly stated. } \\
\text { A quasi-experimental design } \\
\text { was conducted and participants } \\
\text { were selected using randomized } \\
\text { controlled sampling. }\end{array}$ \\
\hline $\begin{array}{l}\text { Hypotheses or } \\
\text { research questions }\end{array}$ & $\begin{array}{l}\text { - Were research questions } \\
\text { and/or hypotheses } \\
\text { explicitly stated? If not, } \\
\text { was their absence } \\
\text { justified? } \\
\text { Were questions and } \\
\text { hypotheses appropriately } \\
\text { worded, with clear } \\
\text { specification of key } \\
\text { variables and the study } \\
\text { population? } \\
\text { Were the } \\
\text { questions/hypotheses } \\
\text { consistent with existing } \\
\text { knowledge? }\end{array}$ & $\begin{array}{l}\text { The aim of the study was } \\
\text { clearly stated as well as the } \\
\text { hypothesis. The hypothesis was } \\
\text { correctly worded and included } \\
\text { key variables and study } \\
\text { population. The key variable } \\
\text { was anxiety levels as measured } \\
\text { by the State Trait Anxiety } \\
\text { Inventory (STAI) scale with } \\
\text { pre- and post-test } \\
\text { measurements. } \\
\text { The hypothesis was consistent } \\
\text { with existing knowledge. }\end{array}$ \\
\hline
\end{tabular}




\begin{tabular}{|c|c|c|}
\hline Literature review & $\begin{array}{l}\text { Was the literature review } \\
\text { up-to-date and based } \\
\text { mainly on primary } \\
\text { sources? } \\
\text { - Did the review provide a } \\
\text { state-of-the-art synthesis of } \\
\text { evidence on the problem? } \\
\text { Did the literature review } \\
\text { provide a strong basis for } \\
\text { the new study? }\end{array}$ & $\begin{array}{l}\text { The literature review section } \\
\text { was thorough and discussed } \\
\text { previous studies conducted on } \\
\text { topic. The review provided a } \\
\text { good synthesis of evidence and } \\
\text { a strong basis for a new study. }\end{array}$ \\
\hline $\begin{array}{l}\text { Conceptual/theoretical } \\
\text { framework }\end{array}$ & $\begin{array}{l}\text { Were key concepts } \\
\text { adequately defined } \\
\text { conceptually? } \\
\text { Was a } \\
\text { conceptual/theoretical } \\
\text { framework articulated- } \\
\text { and, if so, was it } \\
\text { appropriate? If not, is the } \\
\text { absence of a framework } \\
\text { justified? } \\
\text { Were the } \\
\text { questions/hypotheses } \\
\text { consistent with the } \\
\text { framework? }\end{array}$ & $\begin{array}{l}\text { There was no theoretical } \\
\text { framework identified. } \\
\text { Concepts were adequately } \\
\text { defined and thoroughly } \\
\text { described. }\end{array}$ \\
\hline $\begin{array}{l}\text { Method } \\
\text { Protection of human } \\
\text { rights }\end{array}$ & $\begin{array}{l}\text { Were appropriate } \\
\text { procedures used to safe- } \\
\text { guard the rights of study } \\
\text { participants? } \\
\text { - Was the study externally } \\
\text { reviewed by an IRB/ethics } \\
\text { review board? } \\
\text { - Was the study designed to } \\
\text { minimize risks and } \\
\text { maximize benefits to } \\
\text { participants? }\end{array}$ & $\begin{array}{l}\text { The study used appropriate } \\
\text { procedures designed to } \\
\text { safeguard rights of patients and } \\
\text { included an ethics section } \\
\text { describing the process. Written } \\
\text { permission for the study to be } \\
\text { conducted was obtained. It was } \\
\text { noted that a formal ethical } \\
\text { approval was not required in } \\
\text { Turkey because this study does } \\
\text { not pose a threat to human life. } \\
\text { Verbal informed consent was } \\
\text { obtained from all participants. }\end{array}$ \\
\hline Research design & $\begin{array}{l}\text { - Was the most rigorous } \\
\text { design used, given the } \\
\text { study purpose? } \\
\text { - Were appropriate } \\
\text { comparisons made to } \\
\text { enhance interpretability of } \\
\text { the findings? } \\
\text { - Was the number of data } \\
\text { collection points } \\
\text { appropriate? } \\
\text { Did the design minimize } \\
\text { biases and threats to the } \\
\text { internal, construct, and }\end{array}$ & $\begin{array}{l}\text { The design used was consistent } \\
\text { with study goals and purpose } \\
\text { and fit the research question. } \\
\text { Participants were selected using } \\
\text { randomized controlled } \\
\text { sampling. } \\
\text { Appropriate comparisons were } \\
\text { made and the number of data } \\
\text { points were adequate }(\mathrm{N}=64) \text {. }\end{array}$ \\
\hline
\end{tabular}




\begin{tabular}{|c|c|c|}
\hline & $\begin{array}{l}\text { external validity of the } \\
\text { study (e.g., was blinding } \\
\text { used, was attrition } \\
\text { minimized)? }\end{array}$ & \\
\hline $\begin{array}{l}\text { Population and } \\
\text { sample }\end{array}$ & $\begin{array}{l}\text { Was the population } \\
\text { identified? Was the } \\
\text { sample described in } \\
\text { sufficient detail? } \\
\text { - Was the best possible } \\
\text { sampling design used to } \\
\text { enhance the sample's } \\
\text { representativeness? Were } \\
\text { sampling biases } \\
\text { minimized? } \\
\text { Was the sample size based } \\
\text { on a power analysis? }\end{array}$ & $\begin{array}{l}\text { The population was identified } \\
\text { in detail in the introduction } \\
\text { section. } \\
\text { The sample was clearly } \\
\text { identified and described as } \\
\text { being recruited from a urology } \\
\text { clinic in Aziziye Research } \\
\text { Hospital, Suleyman Demirel } \\
\text { Medical Centre and Ataturk } \\
\text { University. No flowchart was } \\
\text { made to identify sample size or } \\
\text { early termination. } \\
\text { Biases included small sample } \\
\text { size, as well as selection bias as } \\
\text { it was only men were eligible } \\
\text { and who agreed to participate in } \\
\text { one geographical area of } \\
\text { Turkey. The sample size was } \\
\text { based on a power analysis. } \\
\text { Alpha level was set at } 0.05 \text { and } \\
\text { reliability was } 95 \% \text { during } \\
\text { calculation of power analysis. } \\
\text { Although the sample size was } \\
\text { noted to be small, it is } \\
\text { comparable to previous studies } \\
\text { performed on same topic and it } \\
\text { was based on a power analysis. }\end{array}$ \\
\hline $\begin{array}{l}\text { Data collection and } \\
\text { measurement }\end{array}$ & $\begin{array}{l}\text { - Were the operational and } \\
\text { conceptual definitions } \\
\text { congruent? } \\
\text { Were key variables } \\
\text { measured using an } \\
\text { appropriate method (e.g., } \\
\text { interviews, observations, } \\
\text { and so on)? } \\
\text { - Were specific instruments } \\
\text { adequately described and } \\
\text { were they good choices, } \\
\text { given the study population } \\
\text { and the variables being } \\
\text { studied? } \\
\text { Did the report provide } \\
\text { evidence that the data } \\
\text { collection methods yielded } \\
\text { data that were reliable, } \\
\text { valid and responsive? }\end{array}$ & $\begin{array}{l}\text { The authors performed the } \\
\text { study how they conceptualized } \\
\text { it. } \\
\text { Key variables were measured } \\
\text { appropriately using STAI } \\
\text { scores. } \\
\text { The report provided evidence } \\
\text { that measurement (STAI) was } \\
\text { valid and reliable. It was } \\
\text { translated and discussed with a } \\
\text { group of experts to determine } \\
\text { content validity as well. } \\
\text { Cronbach's alpha of STAI } \\
\text { yielded score of } 0.94 \text {. }\end{array}$ \\
\hline
\end{tabular}




\begin{tabular}{|c|c|c|}
\hline Procedures & $\begin{array}{l}\text { If there was an } \\
\text { intervention, was it } \\
\text { adequately described, and } \\
\text { was it rigorously } \\
\text { developed and } \\
\text { implemented? Did most } \\
\text { participants allocated to } \\
\text { the intervention group } \\
\text { actually receive it? Was } \\
\text { there evidence of } \\
\text { intervention fidelity? } \\
\text { Were data collected in a } \\
\text { manner that minimized } \\
\text { bias? Were the staff who } \\
\text { collected data } \\
\text { appropriately trained? }\end{array}$ & $\begin{array}{l}\text { Intervention was adequately } \\
\text { described. } \\
\text { All } 32 \text { participants in control } \\
\text { group remained in that group. } \\
\text { All } 32 \text { participants in music } \\
\text { group actually received music. } \\
\text { All interventions were } \\
\text { administered as intended. } \\
\text { It was not noted if the staff were } \\
\text { trained or not. }\end{array}$ \\
\hline Data Analysis & $\begin{array}{l}\text { Were analyses undertaken } \\
\text { to address each research } \\
\text { question or test each } \\
\text { hypothesis? } \\
\text { - Were appropriate } \\
\text { statistical methods used, } \\
\text { given the level of } \\
\text { measurement of the } \\
\text { variables, number of } \\
\text { groups being compared, } \\
\text { and assumptions of the } \\
\text { texts? } \\
\text { Was a powerful analytic } \\
\text { method used? (e.g., did } \\
\text { the analysis help to control } \\
\text { for confounding } \\
\text { variables)? } \\
\text { Were type I and Type II } \\
\text { errors avoided or } \\
\text { minimized? } \\
\text { In intervention studies, } \\
\text { was an intention-to-treat } \\
\text { analysis performed? } \\
\text { Were problems of missing } \\
\text { values evaluated and } \\
\text { adequately addressed? }\end{array}$ & $\begin{array}{l}\text { The data were well analyzed to } \\
\text { address the research question. } \\
\text { The statistical method was } \\
\text { appropriate. } \\
\text { Powerful analytic methods were } \\
\text { not used. } \\
\text { Data were coded and used in } \\
\text { database using SPSS version } \\
\text { 10.0. Demographic information } \\
\text { was compared using chi-square } \\
\text { and independent samples t-tests } \\
\text { were used to compare scores of } \\
\text { experimental and control } \\
\text { groups. Paired t-tests were used } \\
\text { to examine significant } \\
\text { differences between pre- and } \\
\text { posttest STAI. } \\
\text { Intention-to-treat analysis was } \\
\text { not performed. } \\
\text { No missing values were } \\
\text { identified, nor were they } \\
\text { addressed. }\end{array}$ \\
\hline Findings & $\begin{array}{l}\text { Was information about } \\
\text { statistical significance } \\
\text { presented? Was } \\
\text { information about effect } \\
\text { size and precision of } \\
\text { estimates (confidence } \\
\text { intervals) presented? }\end{array}$ & $\begin{array}{l}\text { Statistical significance of STAI } \\
\text { scores was conducted and the } \\
\text { level for this study was } 0.05 \text {. } \\
\text { The findings were adequately } \\
\text { summarized including three } \\
\text { tables. } \\
\text { Information was not provided } \\
\text { about confidence intervals. }\end{array}$ \\
\hline
\end{tabular}




\begin{tabular}{|c|c|c|}
\hline & $\begin{array}{l}\text { Were the findings } \\
\text { adequately summarized, } \\
\text { with good use of tables } \\
\text { and figures? } \\
\text { Were findings reported in } \\
\text { a manner that facilitates a } \\
\text { meta-analysis, and with } \\
\text { sufficient information } \\
\text { needed for EBP? }\end{array}$ & \\
\hline $\begin{array}{l}\text { Discussion } \\
\text { Interpretation of the } \\
\text { findings }\end{array}$ & $\begin{array}{l}\text { - Were all major findings } \\
\text { interpreted and discussed } \\
\text { within the context of prior } \\
\text { research and/or the study's } \\
\text { conceptual framework? } \\
\text { - Were casual inferences, if } \\
\text { any, justified? } \\
\text { - Was the issue of clinical } \\
\text { significance discussed? } \\
\text { - Were interpretations well- } \\
\text { founded and consistent } \\
\text { with the study's } \\
\text { limitations? } \\
\text { Did the report address the } \\
\text { issue of the } \\
\text { generalizability of the } \\
\text { findings? }\end{array}$ & $\begin{array}{l}\text { The findings were discussed in } \\
\text { the context of the research } \\
\text { question. } \\
\text { Casual inferences were made } \\
\text { and justified given the results of } \\
\text { the study. } \\
\text { Clinical significance was } \\
\text { discussed and interpretations } \\
\text { appropriate. } \\
\text { The study did not attempt to } \\
\text { generalize and overtly stated it } \\
\text { is not generalizable to all male } \\
\text { patients undergoing urogenital } \\
\text { surgery or to all Turkish people. }\end{array}$ \\
\hline $\begin{array}{l}\text { Implications/ } \\
\text { recommendations }\end{array}$ & $\begin{array}{l}\text { Did the researchers discuss } \\
\text { the implications of the } \\
\text { study for clinical practice } \\
\text { or further research-and } \\
\text { were those implications } \\
\text { reasonable and complete? }\end{array}$ & $\begin{array}{l}\text { There was an implication for } \\
\text { nursing practice section } \\
\text { included which was reasonable } \\
\text { and complete. }\end{array}$ \\
\hline $\begin{array}{l}\text { General Issues } \\
\text { Presentation }\end{array}$ & $\begin{array}{l}\text { Was the report well- } \\
\text { written, organized, and } \\
\text { sufficiently detailed for } \\
\text { critical analysis? } \\
\text { - In intervention studies, } \\
\text { was a CONSORT } \\
\text { flowchart provided to } \\
\text { show the flow of } \\
\text { participants in the study? } \\
\text { Was the report written in a } \\
\text { manner that makes the } \\
\text { findings accessible to } \\
\text { practicing nurses? }\end{array}$ & $\begin{array}{l}\text { The report was easy to follow, } \\
\text { well organized and sufficiently } \\
\text { detailed. } \\
\text { Report was written in a manner } \\
\text { that is accessible for practicing } \\
\text { nurses. }\end{array}$ \\
\hline Researcher credibility & $\begin{array}{l}\text { Do the researchers' } \\
\text { clinical, substantive, or } \\
\text { methodologic } \\
\text { qualifications and } \\
\text { experience enhance }\end{array}$ & $\begin{array}{l}\text { There was information about } \\
\text { the authors' qualifications and } \\
\text { experience on the first page } \\
\text { which included their titles and }\end{array}$ \\
\hline
\end{tabular}




\begin{tabular}{|l|c|l|}
\hline & $\begin{array}{l}\text { confidence in the findings } \\
\text { and their interpretation? }\end{array}$ & $\begin{array}{l}\text { place of employment/ } \\
\text { affiliation. }\end{array}$ \\
\hline Summary assessment & $\begin{array}{l}\text { Despite any limitations, do } \\
\text { the study findings appear } \\
\text { to be valid_do you have } \\
\text { confidence in the truth } \\
\text { value of the results? } \\
\text { Does the study contribute } \\
\text { any meaningful evidence } \\
\text { that can be used in nursing } \\
\text { practice or that is useful to } \\
\text { the nursing discipline? }\end{array}$ & $\begin{array}{l}\text { Study appears to be valid and to } \\
\text { have truth value of the results. } \\
\text { The study identified a problem } \\
\text { and showed a need for further } \\
\text { research in the male population } \\
\text { with a larger sample size. }\end{array}$ \\
& \multicolumn{2}{|c|}{} \\
\hline
\end{tabular}




\section{Appendix A-2}

Dong, Y. \& Li, Y. (2012). Preoperative music intervention for patients undergoing cesarean delivery. International Journal of Gynecology \& Obstetrics,119(1), 81-83. doi:10.1016/j.ijgo.2012.05.017

\begin{tabular}{|c|c|c|}
\hline Aspect of the Report & Critiquing Questions & $\begin{array}{l}\text { Detailed Critiquing } \\
\text { Guidelines }\end{array}$ \\
\hline Title & $\begin{array}{l}\text { Is the title a good one, } \\
\text { succinctly suggesting key } \\
\text { variables and the study } \\
\text { population? }\end{array}$ & $\begin{array}{l}\text { The title clearly identified the } \\
\text { subject, location, and time } \\
\text { frame of the study. }\end{array}$ \\
\hline Abstract & $\begin{array}{l}\text { Did the abstract clearly and } \\
\text { concisely summarize the } \\
\text { main features of the report } \\
\text { (problem, methods, results, } \\
\text { conclusions)? }\end{array}$ & $\begin{array}{l}\text { The abstract thoroughly } \\
\text { outlined all the components of } \\
\text { the study and included } \\
\text { objective, methods, results and } \\
\text { conclusions. }\end{array}$ \\
\hline $\begin{array}{l}\text { Introduction } \\
\text { Statement of the } \\
\text { problem }\end{array}$ & $\begin{array}{l}\text { - Was the problem stated } \\
\text { unambiguously, and was it } \\
\text { easy to identify? } \\
\text { - Is the problem statement } \\
\text { build a persuasive argument } \\
\text { for the new study? } \\
\text { - Was there a good match } \\
\text { between the research } \\
\text { problem and the methods } \\
\text { used -that is, was a } \\
\text { quantitative approach } \\
\text { appropriate? }\end{array}$ & $\begin{array}{l}\text { The problem was easily } \\
\text { identified, clear, and suggested } \\
\text { a need for a new study. } \\
\text { The introduction suggested } \\
\text { benefits of music and its } \\
\text { anxiolytic effects and built a } \\
\text { persuasive argument } \\
\text { investigating maternal anxiety. } \\
\text { A present prospective, } \\
\text { randomized control study was } \\
\text { a quantitative approach and } \\
\text { appropriate for the research } \\
\text { problem. }\end{array}$ \\
\hline $\begin{array}{l}\text { Hypotheses or } \\
\text { research questions }\end{array}$ & $\begin{array}{l}\text { - Were research questions } \\
\text { and/or hypotheses explicitly } \\
\text { stated? If not, was their } \\
\text { absence justified? } \\
\text { - Were questions and } \\
\text { hypotheses appropriately } \\
\text { worded, with clear } \\
\text { specification of key } \\
\text { variables and the study } \\
\text { population? } \\
\text { Were the } \\
\text { questions/hypotheses } \\
\text { consistent with existing } \\
\text { knowledge? }\end{array}$ & $\begin{array}{l}\text { The objective of the study was } \\
\text { clearly stated. No hypotheses } \\
\text { were presented or explicitly } \\
\text { stated. } \\
\text { No research questions were } \\
\text { explicitly included. } \\
\text { The research problem was } \\
\text { consistent with existing } \\
\text { knowledge. }\end{array}$ \\
\hline Literature review & $\begin{array}{l}\text { Was the literature review } \\
\text { up-to-date and based } \\
\text { mainly on primary sources? } \\
\text { Did the review provide a } \\
\text { state-of-the-art synthesis of } \\
\text { evidence on the problem? }\end{array}$ & $\begin{array}{l}\text { The literature review was brief, } \\
\text { but built a strong basis for new } \\
\text { study. } \\
\text { Primary sources used with mix } \\
\text { of up-to-date and not up-to- } \\
\text { date sources included. }\end{array}$ \\
\hline
\end{tabular}




\begin{tabular}{|c|c|c|}
\hline & $\begin{array}{l}\text { Did the literature review } \\
\text { provide a strong basis for } \\
\text { the new study? }\end{array}$ & \\
\hline $\begin{array}{l}\text { Conceptual/theoretical } \\
\text { framework }\end{array}$ & $\begin{array}{l}\text { Were key concepts } \\
\text { adequately defined } \\
\text { conceptually? } \\
\text { Was a } \\
\text { conceptual/theoretical } \\
\text { framework articulated- } \\
\text { and, if so, was it } \\
\text { appropriate? If not, is the } \\
\text { absence of a framework } \\
\text { justified? } \\
\text { Were the } \\
\text { questions/hypotheses } \\
\text { consistent with the } \\
\text { framework? }\end{array}$ & $\begin{array}{l}\text { Concepts were adequately } \\
\text { defined and no theoretical } \\
\text { framework was identified. }\end{array}$ \\
\hline $\begin{array}{l}\text { Method } \\
\text { Protection of human } \\
\text { rights }\end{array}$ & $\begin{array}{l}\text { Were appropriate } \\
\text { procedures used to safe- } \\
\text { guard the rights of study } \\
\text { participants? } \\
\text { - Was the study externally } \\
\text { reviewed by an IRB/ethics } \\
\text { review board? } \\
\text { - Was the study designed to } \\
\text { minimize risks and } \\
\text { maximize benefits to } \\
\text { participants? }\end{array}$ & $\begin{array}{l}\text { The study used appropriate } \\
\text { procedures to safeguard rights } \\
\text { of patients. } \\
\text { The study was approved by the } \\
\text { Ethics Committee of China } \\
\text { Medical University affiliated } \\
\text { with Shengjinj Hospital. } \\
\text { Informed consent was obtained } \\
\text { from all participants. } \\
\text { The authors overtly stated it } \\
\text { was done in a safe noninvasive } \\
\text { way, to minimize risks and } \\
\text { maximize benefits to the } \\
\text { participants. }\end{array}$ \\
\hline Research design & $\begin{array}{l}\text { - Was the most rigorous } \\
\text { design used, given the study } \\
\text { purpose? } \\
\text { Were appropriate } \\
\text { comparisons made to } \\
\text { enhance interpretability of } \\
\text { the findings? } \\
\text { - Was the number of data } \\
\text { collection points } \\
\text { appropriate? } \\
\text { Did the design minimize } \\
\text { biases and threats to the } \\
\text { internal, construct, and } \\
\text { external validity of the } \\
\text { study (e.g., was blinding } \\
\text { used, was attrition } \\
\text { minimized)? }\end{array}$ & $\begin{array}{l}\text { The design used was consistent } \\
\text { with study goals and most } \\
\text { rigorous. Randomization was } \\
\text { done by a computer generated } \\
\text { random number table to assign } \\
\text { participants to the control and } \\
\text { study group. } \\
\text { Appropriate comparisons were } \\
\text { made between study and } \\
\text { control group. The outcome } \\
\text { measures compared differences } \\
\text { in anxiety scores and heart rate } \\
\text { variability, as well as pain } \\
\text { scores. } \\
\text { Number of data points was } \\
\text { adequate (N=60). }\end{array}$ \\
\hline $\begin{array}{l}\text { Population and } \\
\text { sample }\end{array}$ & $\begin{array}{l}\text { Was the population } \\
\text { identified? Was the sample }\end{array}$ & $\begin{array}{l}\text { The population was identified } \\
\text { in the introduction. The sample }\end{array}$ \\
\hline
\end{tabular}




\begin{tabular}{|c|c|c|}
\hline & $\begin{array}{l}\text { described in sufficient } \\
\text { detail? } \\
\text { - Was the best possible } \\
\text { sampling design used to } \\
\text { enhance the sample's } \\
\text { representativeness? Were } \\
\text { sampling biases } \\
\text { minimized? } \\
\text { - Was the sample size based } \\
\text { on a power analysis? }\end{array}$ & $\begin{array}{l}\text { was described in sufficient } \\
\text { detail. Power analysis was used } \\
\text { to calculate sample size } \\
\text { needed, rendering } 80 \% \text { power } \\
\text { to detect a clinically significant } \\
\text { difference at } \alpha=0.05 \text { and } \\
\beta=0.20 \text {. } \\
\text { A flowchart was not utilized. } \\
\text { The study did not include if } \\
\text { blinding was used and this may } \\
\text { have contributed to bias. } \\
\text { Sample size was comparable to } \\
\text { other studies done on similar } \\
\text { topic. }\end{array}$ \\
\hline $\begin{array}{l}\text { Data collection and } \\
\text { measurement }\end{array}$ & $\begin{array}{l}\text { Were the operational and } \\
\text { conceptual definitions } \\
\text { congruent? } \\
\text { Were key variables } \\
\text { measured using an } \\
\text { appropriate method (e.g., } \\
\text { interviews, observations, } \\
\text { and so on)? } \\
\text { Were specific instruments } \\
\text { adequately described and } \\
\text { were they good choices, } \\
\text { given the study population } \\
\text { and the variables being } \\
\text { studied? } \\
\text { Did the report provide } \\
\text { evidence that the data } \\
\text { collection methods yielded } \\
\text { data that were reliable, } \\
\text { valid and responsive? }\end{array}$ & $\begin{array}{l}\text { The authors performed the } \\
\text { study how they conceptualized } \\
\text { it. } \\
\text { Key variables were adequately } \\
\text { described. } \\
\text { Outcomes were measured } \\
\text { using a visual analog scale } \\
\text { (VAS) for pain, Zung Self- } \\
\text { Rating Anxiety Scale (SAS), } \\
\text { and heart rate variability } \\
\text { (HRV) via a Holter Monitor. } \\
\text { No evidence was provided to } \\
\text { show collection methods were } \\
\text { reliable and/or valid. }\end{array}$ \\
\hline Procedures & $\begin{array}{l}\text { If there was an intervention, } \\
\text { was it adequately described, } \\
\text { and was it rigorously } \\
\text { developed and } \\
\text { implemented? Did most } \\
\text { participants allocated to the } \\
\text { intervention group actually } \\
\text { receive it? Was there } \\
\text { evidence of intervention } \\
\text { fidelity? } \\
\text { Were data collected in a } \\
\text { manner that minimized } \\
\text { bias? Were the staff who } \\
\text { collected data appropriately } \\
\text { trained? }\end{array}$ & $\begin{array}{l}\text { The intervention performed } \\
\text { was adequately described, but } \\
\text { would have benefitted from } \\
\text { more detail and expansion. } \\
\text { The study included a total of } \\
60 \text { participants, with } 30 \\
\text { participants randomized to the } \\
\text { study group and } 30 \text { participants } \\
\text { randomized to the control } \\
\text { group. } \\
\text { All interventions were } \\
\text { administered as intended. } \\
\text { It was not noted if the staff } \\
\text { were trained or not. }\end{array}$ \\
\hline Data Analysis & $\begin{array}{l}\text { Were analyses undertaken } \\
\text { to address each research }\end{array}$ & $\begin{array}{l}\text { The data were well analyzed to } \\
\text { address the research question. }\end{array}$ \\
\hline
\end{tabular}




\begin{tabular}{|c|c|c|}
\hline & $\begin{array}{l}\text { question or test each } \\
\text { hypothesis? } \\
\text { - Were appropriate statistical } \\
\text { methods used, given the } \\
\text { level of measurement of the } \\
\text { variables, number of groups } \\
\text { being compared, and } \\
\text { assumptions of the texts? } \\
\text { - Was a powerful analytic } \\
\text { method used? (e.g., did the } \\
\text { analysis help to control for } \\
\text { confounding variables)? } \\
\text { Were type I and Type II } \\
\text { errors avoided or } \\
\text { minimized? } \\
\text { In intervention studies, was } \\
\text { an intention-to-treat } \\
\text { analysis performed? } \\
\text { Were problems of missing } \\
\text { values evaluated and } \\
\text { adequately addressed? }\end{array}$ & $\begin{array}{l}\text { The statistical method was } \\
\text { appropriate. } \\
\text { Data were analyzed using } \\
\text { SPSS version } 13.0 \text {. } \\
\text { Paired t-tests were used to } \\
\text { compare changes and } \\
\text { differences between groups. } \\
\mathrm{P}<0.05 \text { was considered } \\
\text { significant. } \\
\text { Intention-to-treat analysis was } \\
\text { not performed. } \\
\text { No missing values were } \\
\text { identified, nor were they } \\
\text { addressed. }\end{array}$ \\
\hline Findings & $\begin{array}{l}\text { - Was information about } \\
\text { statistical significance } \\
\text { presented? Was } \\
\text { information about effect } \\
\text { size and precision of } \\
\text { estimates (confidence } \\
\text { intervals) presented? } \\
\text { - Were the findings } \\
\text { adequately summarized, } \\
\text { with good use of tables and } \\
\text { figures? } \\
\text { Were findings reported in a } \\
\text { manner that facilitates a } \\
\text { meta-analysis, and with } \\
\text { sufficient information } \\
\text { needed for EBP? }\end{array}$ & $\begin{array}{l}\text { The findings were summarized } \\
\text { in two tables. } \\
\text { Information was provided } \\
\text { about confidence intervals and } \\
\text { effect size. } \\
\text { Information provided was } \\
\text { sufficient for EBP. }\end{array}$ \\
\hline $\begin{array}{l}\text { Discussion } \\
\text { Interpretation of the } \\
\text { findings }\end{array}$ & $\begin{array}{l}\text { - Were all major findings } \\
\text { interpreted and discussed } \\
\text { within the context of prior } \\
\text { research and/or the study’s } \\
\text { conceptual framework? } \\
\text { - Were casual inferences, if } \\
\text { any, justified? } \\
\text { - Was the issue of clinical } \\
\text { significance discussed? } \\
\text { - Were interpretations well- } \\
\text { founded and consistent with } \\
\text { the study’s limitations? }\end{array}$ & $\begin{array}{l}\text { The findings were discussed in } \\
\text { the context of the research } \\
\text { question. } \\
\text { Casual inferences were made } \\
\text { and justified given the results } \\
\text { of the study. } \\
\text { Clinical significance was } \\
\text { discussed and interpretations } \\
\text { appropriate. } \\
\text { The study did not attempt to } \\
\text { generalize to areas outside of } \\
\text { women undergoing cesarean } \\
\text { delivery. }\end{array}$ \\
\hline
\end{tabular}




\begin{tabular}{|c|c|c|}
\hline & $\begin{array}{l}\text { Did the report address the } \\
\text { issue of the generalizability } \\
\text { of the findings? }\end{array}$ & \\
\hline $\begin{array}{l}\text { Implications/ } \\
\text { recommendations }\end{array}$ & $\begin{array}{l}\text { Did the researchers discuss } \\
\text { the implications of the } \\
\text { study for clinical practice or } \\
\text { further research-and were } \\
\text { those implications } \\
\text { reasonable and complete? }\end{array}$ & $\begin{array}{l}\text { The authors reasonably } \\
\text { identified the need for further } \\
\text { study comparing music } \\
\text { interventions with other } \\
\text { methods that would decrease } \\
\text { sympathetic and increase } \\
\text { parasympathetic activity. } \\
\text { The implications made were } \\
\text { reasonable and complete. }\end{array}$ \\
\hline $\begin{array}{l}\text { General Issues } \\
\text { Presentation }\end{array}$ & $\begin{array}{l}\text { Was the report well-written, } \\
\text { organized, and sufficiently } \\
\text { detailed for critical } \\
\text { analysis? } \\
\text { In intervention studies, was } \\
\text { a CONSORT flowchart } \\
\text { provided to show the flow } \\
\text { of participants in the study? } \\
\text { Was the report written in a } \\
\text { manner that makes the } \\
\text { findings accessible to } \\
\text { practicing nurses? }\end{array}$ & $\begin{array}{l}\text { The report was easy to follow, } \\
\text { well organized and adequately } \\
\text { detailed. } \\
\text { The report was written in a } \\
\text { manner that is accessible for } \\
\text { practicing nurses. }\end{array}$ \\
\hline Researcher credibility & $\begin{array}{l}\text { Do the researchers' clinical, } \\
\text { substantive, or } \\
\text { methodologic qualifications } \\
\text { and experience enhance } \\
\text { confidence in the findings } \\
\text { and their interpretation? }\end{array}$ & $\begin{array}{l}\text { There was information about } \\
\text { the author's qualifications and } \\
\text { experience on the first page. }\end{array}$ \\
\hline Summary assessment & $\begin{array}{l}\text { Despite any limitations, do } \\
\text { the study findings appear to } \\
\text { be valid-do you have } \\
\text { confidence in the truth } \\
\text { value of the results? } \\
\text { - Does the study contribute } \\
\text { any meaningful evidence } \\
\text { that can be used in nursing } \\
\text { practice or that is useful to } \\
\text { the nursing discipline? }\end{array}$ & $\begin{array}{l}\text { The study appeared to be valid } \\
\text { and appeared to have truth } \\
\text { value of the results. } \\
\text { The study identified a problem } \\
\text { and showed a need for further } \\
\text { research, possibly comparing } \\
\text { music interventions with other } \\
\text { methods that would decrease } \\
\text { sympathetic and increase } \\
\text { parasympathetic activity. }\end{array}$ \\
\hline
\end{tabular}




\section{Appendix A-3}

Ertuğ, N., Ulusoylu, Ö, Bal, A., \& Özgür, H. (2017). Comparison of the effectiveness of two different interventions to reduce preoperative anxiety: A randomized controlled study. Nursing \& Health Sciences,19(2), 250-256. doi:10.1111/nhs.12339

\begin{tabular}{|c|c|c|}
\hline Aspect of the Report & Critiquing Questions & $\begin{array}{l}\text { Detailed Critiquing } \\
\text { Guidelines }\end{array}$ \\
\hline Title & $\begin{array}{l}\text { Is the title a good one, } \\
\text { succinctly suggesting key } \\
\text { variables and the study } \\
\text { population? }\end{array}$ & $\begin{array}{l}\text { The title clearly identified the } \\
\text { subject, location, and time } \\
\text { frame of the study. }\end{array}$ \\
\hline Abstract & $\begin{array}{l}\text { Did the abstract clearly and } \\
\text { concisely summarize the } \\
\text { main features of the report } \\
\text { (problem, methods, results, } \\
\text { conclusions)? }\end{array}$ & $\begin{array}{l}\text { The abstract outlined all the } \\
\text { components of the study and } \\
\text { included objective, methods, } \\
\text { results and conclusions. }\end{array}$ \\
\hline $\begin{array}{l}\text { Introduction } \\
\text { Statement of the } \\
\text { problem }\end{array}$ & $\begin{array}{l}\text { Was the problem stated } \\
\text { unambiguously, and was it } \\
\text { easy to identify? } \\
\text { Is the problem statement } \\
\text { build a persuasive } \\
\text { argument for the new } \\
\text { study? } \\
\text { Was there a good match } \\
\text { between the research } \\
\text { problem and the methods } \\
\text { used -that is, was a } \\
\text { quantitative approach } \\
\text { appropriate? }\end{array}$ & $\begin{array}{l}\text { The problem was easily } \\
\text { identified, clear, and suggested } \\
\text { a need for a new study. } \\
\text { The introduction suggested } \\
\text { benefits of music, specifically } \\
\text { nature sounds and relaxation } \\
\text { exercise and its anxiolytic } \\
\text { effects and built a persuasive } \\
\text { argument investigating } \\
\text { preoperative anxiety. } \\
\text { A repeated measures } \\
\text { randomized controlled trial was } \\
\text { used, with two intervention } \\
\text { group and a control group. }\end{array}$ \\
\hline $\begin{array}{l}\text { Hypotheses or } \\
\text { research questions }\end{array}$ & $\begin{array}{l}\text { Were research questions } \\
\text { and/or hypotheses } \\
\text { explicitly stated? If not, } \\
\text { was their absence justified? } \\
\text { Were questions and } \\
\text { hypotheses appropriately } \\
\text { worded, with clear } \\
\text { specification of key } \\
\text { variables and the study } \\
\text { population? } \\
\text { Were the } \\
\text { questions/hypotheses } \\
\text { consistent with existing } \\
\text { knowledge? }\end{array}$ & $\begin{array}{l}\text { The objective of the study was } \\
\text { clearly stated, with key } \\
\text { variables identified. The key } \\
\text { variables included nature } \\
\text { sounds and relaxation } \\
\text { exercises. } \\
\text { The hypothesis was explicitly } \\
\text { stated, with clear specification } \\
\text { of variables and study } \\
\text { population. The hypothesis was } \\
\text { consistent with existing } \\
\text { knowledge. } \\
\text { No research questions were } \\
\text { explicitly included. }\end{array}$ \\
\hline Literature review & $\begin{array}{l}\text { Was the literature review } \\
\text { up-to-date and based } \\
\text { mainly on primary sources? }\end{array}$ & $\begin{array}{l}\text { The literature review was } \\
\text { thorough and built a strong } \\
\text { basis for new study. } \\
\text { Primary sources were used } \\
\text { with mix of up-to-date and not }\end{array}$ \\
\hline
\end{tabular}




\begin{tabular}{|c|c|c|}
\hline & $\begin{array}{l}\text { Did the review provide a } \\
\text { state-of-the-art synthesis of } \\
\text { evidence on the problem? } \\
\text { - Did the literature review } \\
\text { provide a strong basis for } \\
\text { the new study? }\end{array}$ & $\begin{array}{l}\text { up-to-date sources included, } \\
\text { i.e. greater than } 10 \text { years from } \\
\text { publication. }\end{array}$ \\
\hline $\begin{array}{l}\text { Conceptual/theoretical } \\
\text { framework }\end{array}$ & $\begin{array}{l}\text { Were key concepts } \\
\text { adequately defined } \\
\text { conceptually? } \\
\text { Was a } \\
\text { conceptual/theoretical } \\
\text { framework articulated- } \\
\text { and, if so, was it } \\
\text { appropriate? If not, is the } \\
\text { absence of a framework } \\
\text { justified? } \\
\text { Were the } \\
\text { questions/hypotheses } \\
\text { consistent with the } \\
\text { framework? }\end{array}$ & $\begin{array}{l}\text { Concepts were adequately } \\
\text { defined and no theoretical } \\
\text { framework identified. }\end{array}$ \\
\hline $\begin{array}{l}\text { Method } \\
\text { Protection of human } \\
\text { rights }\end{array}$ & $\begin{array}{l}\text { Were appropriate } \\
\text { procedures used to safe- } \\
\text { guard the rights of study } \\
\text { participants? } \\
\text { - Was the study externally } \\
\text { reviewed by an IRB/ethics } \\
\text { review board? } \\
\text { - Was the study designed to } \\
\text { minimize risks and } \\
\text { maximize benefits to } \\
\text { participants? }\end{array}$ & $\begin{array}{l}\text { The study used appropriate } \\
\text { procedures to safeguard rights } \\
\text { of participants. } \\
\text { The study was approved by the } \\
\text { Turgut Özal University } \\
\text { Research Ethics Committee, } \\
\text { and written permission was } \\
\text { obtained from the hospital. } \\
\text { Informed consent was obtained } \\
\text { from all participants. } \\
\text { The authors stated the } \\
\text { interventions did not harm or } \\
\text { compromise participants in any } \\
\text { way. The authors informed } \\
\text { patients that participation was } \\
\text { voluntary and that they could } \\
\text { withdraw at any time. }\end{array}$ \\
\hline Research design & $\begin{array}{l}\text { - Was the most rigorous } \\
\text { design used, given the } \\
\text { study purpose? } \\
\text { - Were appropriate } \\
\text { comparisons made to } \\
\text { enhance interpretability of } \\
\text { the findings? } \\
\text { - Was the number of data } \\
\text { collection points } \\
\text { appropriate? } \\
\text { Did the design minimize } \\
\text { biases and threats to the } \\
\text { internal, construct, and }\end{array}$ & $\begin{array}{l}\text { The design used was consistent } \\
\text { with study goals and most } \\
\text { rigorous. A permuted-block } \\
\text { randomization with sealed } \\
\text { envelopes was used to assign } \\
\text { patients randomly to the three } \\
\text { groups. Groups included a } \\
\text { nature sounds group ( } \mathrm{n}=53) \text {, a } \\
\text { relaxation exercise group } \\
(\mathrm{n}=53) \text { and a control group } \\
(\mathrm{n}=53) \text {. To avoid bias with this } \\
\text { technique, a person not } \\
\text { involved in the study randomly }\end{array}$ \\
\hline
\end{tabular}




\begin{tabular}{|c|c|c|}
\hline & $\begin{array}{l}\text { external validity of the } \\
\text { study (e.g., was blinding } \\
\text { used, was attrition } \\
\text { minimized)? }\end{array}$ & $\begin{array}{l}\text { placed participants' names into } \\
\text { envelopes. } \\
\text { There were appropriate } \\
\text { comparisons made between } \\
\text { study and control group. The } \\
\text { outcome measures compared } \\
\text { differences in anxiety scores } \\
\text { using State Anxiety Inventory } \\
\text { scores (SAI) and visual analog } \\
\text { scale (VAS), both to measure } \\
\text { anxiety levels. } \\
\text { The number of data points } \\
\text { were adequate }(\mathrm{N}=159) \text {. }\end{array}$ \\
\hline $\begin{array}{l}\text { Population and } \\
\text { sample }\end{array}$ & $\begin{array}{l}\text { - Was the population } \\
\text { identified? Was the sample } \\
\text { described in sufficient } \\
\text { detail? } \\
\text { - Was the best possible } \\
\text { sampling design used to } \\
\text { enhance the sample's } \\
\text { representativeness? Were } \\
\text { sampling biases } \\
\text { minimized? } \\
\text { - Was the sample size based } \\
\text { on a power analysis? }\end{array}$ & $\begin{array}{l}\text { The population was identified } \\
\text { thoroughly in the introduction. } \\
\text { The sample was described in } \\
\text { sufficient detail. A pilot study } \\
\text { was conducted to determine a } \\
\text { sample size of } 159 \text { patients } \\
\text { necessary using a power } \\
\text { analysis with } \alpha=0.05 \text { and } \\
\beta=0.20 \text {. } \\
\text { A flowchart was utilized and } \\
\text { showed participant enrollment, } \\
\text { refusal, inclusion criteria, and } \\
\text { total number analyzed in each } \\
\text { group. } \\
\text { The study was not blinded and } \\
\text { may have contributed to bias. } \\
\text { Another reason for bias was } \\
\text { that participants spent } 30 \\
\text { minutes with relatives between } \\
\text { second and third measurement } \\
\text { and that may have influenced } \\
\text { anxiety levels. } \\
\text { The sample size was } \\
\text { comparable to other studies } \\
\text { done on similar topic. }\end{array}$ \\
\hline $\begin{array}{l}\text { Data collection and } \\
\text { measurement }\end{array}$ & $\begin{array}{l}\text { Were the operational and } \\
\text { conceptual definitions } \\
\text { congruent? } \\
\text { Were key variables } \\
\text { measured using an } \\
\text { appropriate method (e.g., } \\
\text { interviews, observations, } \\
\text { and so on)? } \\
\text { Were specific instruments } \\
\text { adequately described and } \\
\text { were they good choices, } \\
\text { given the study population }\end{array}$ & $\begin{array}{l}\text { The authors performed the } \\
\text { study how they conceptualized } \\
\text { it. } \\
\text { The key variables were } \\
\text { adequately described. } \\
\text { The outcome measures SAI } \\
\text { and VAS to measure anxiety } \\
\text { levels. } \\
\text { No evidence was provided to } \\
\text { show collection methods were } \\
\text { adequately reliable and/or } \\
\text { valid. }\end{array}$ \\
\hline
\end{tabular}




\begin{tabular}{|c|c|c|}
\hline & $\begin{array}{l}\text { and the variables being } \\
\text { studied? } \\
\text { Did the report provide } \\
\text { evidence that the data } \\
\text { collection methods yielded } \\
\text { data that were reliable, } \\
\text { valid and responsive? }\end{array}$ & \\
\hline Procedures & $\begin{array}{l}\text { - If there was an } \\
\text { intervention, was it } \\
\text { adequately described, and } \\
\text { was it rigorously developed } \\
\text { and implemented? Did } \\
\text { most participants allocated } \\
\text { to the intervention group } \\
\text { actually receive it? Was } \\
\text { there evidence of } \\
\text { intervention fidelity? } \\
\text { Were data collected in a } \\
\text { manner that minimized } \\
\text { bias? Were the staff who } \\
\text { collected data appropriately } \\
\text { trained? }\end{array}$ & $\begin{array}{l}\text { The intervention performed } \\
\text { was thoroughly described. } \\
\text { The study included a total of } \\
159 \text { participants, with } 30 \\
\text { participants randomized to } \\
\text { each of the three groups, each } \\
\text { containing } 53 \text { participants. } \\
\text { All interventions were } \\
\text { administered as intended. } \\
\text { The staff were not noted to be } \\
\text { trained or not. }\end{array}$ \\
\hline Data Analysis & $\begin{array}{l}\text { - Were analyses undertaken } \\
\text { to address each research } \\
\text { question or test each } \\
\text { hypothesis? } \\
\text { - Were appropriate statistical } \\
\text { methods used, given the } \\
\text { level of measurement of the } \\
\text { variables, number of groups } \\
\text { being compared, and } \\
\text { assumptions of the texts? } \\
\text { - Was a powerful analytic } \\
\text { method used? (e.g., did the } \\
\text { analysis help to control for } \\
\text { confounding variables)? } \\
\text { Were type I and Type II } \\
\text { errors avoided or } \\
\text { minimized? } \\
\text { In intervention studies, was } \\
\text { an intention-to-treat } \\
\text { analysis performed? } \\
\text { Were problems of missing } \\
\text { values evaluated and } \\
\text { adequately addressed? }\end{array}$ & $\begin{array}{l}\text { The data were well analyzed to } \\
\text { address the research question. } \\
\text { The statistical method was } \\
\text { appropriate. } \\
\text { The data were analyzed using } \\
\text { SPSS version } 21.0 \text {. The chi- } \\
\text { square test was used to } \\
\text { evaluate the homogeneity of } \\
\text { the participants within groups. } \\
\text { One-way analysis of variance } \\
\text { (ANOVA) was completed to } \\
\text { compare anxiety levels } \\
\text { between groups through } \\
\text { measurement of time. } \\
\text { Independent variables were } \\
\text { evaluated with independent t- } \\
\text { test and one-way ANOVA. } \\
\text { Post hoc analysis was } \\
\text { performed to look at } \\
\text { differences between groups. A } \\
\text { P value of }<0.005 \text { was accepted } \\
\text { as statistically significant, the } \\
\text { repeated-measures ANOVA } \\
\text { significance level was set at } \\
\text { P } \leq 0.016 \text {. } \\
\text { Intention-to-treat analysis was } \\
\text { not performed. }\end{array}$ \\
\hline
\end{tabular}




\begin{tabular}{|c|c|c|}
\hline & & $\begin{array}{l}\text { There were no missing values } \\
\text { identified, nor were they } \\
\text { addressed. }\end{array}$ \\
\hline Findings & $\begin{array}{l}\text { - Was information about } \\
\text { statistical significance } \\
\text { presented? Was } \\
\text { information about effect } \\
\text { size and precision of } \\
\text { estimates (confidence } \\
\text { intervals) presented? } \\
\text { - Were the findings } \\
\text { adequately summarized, } \\
\text { with good use of tables and } \\
\text { figures? } \\
\text { Were findings reported in a } \\
\text { manner that facilitates a } \\
\text { meta-analysis, and with } \\
\text { sufficient information } \\
\text { needed for EBP? }\end{array}$ & $\begin{array}{l}\text { The findings were summarized } \\
\text { in two tables and two figures. } \\
\text { The figures identified VAS and } \\
\text { SAI scores over time plotted } \\
\text { over time. } \\
\text { No information was provided } \\
\text { about confidence intervals and } \\
\text { effect size. } \\
\text { Information provided was } \\
\text { sufficient for EBP. }\end{array}$ \\
\hline $\begin{array}{l}\text { Discussion } \\
\text { Interpretation of the } \\
\text { findings }\end{array}$ & $\begin{array}{l}\text { - Were all major findings } \\
\text { interpreted and discussed } \\
\text { within the context of prior } \\
\text { research and/or the study’s } \\
\text { conceptual framework? } \\
\text { - Were casual inferences, if } \\
\text { any, justified? } \\
\text { - Was the issue of clinical } \\
\text { significance discussed? } \\
\text { Were interpretations well- } \\
\text { founded and consistent } \\
\text { with the study's } \\
\text { limitations? } \\
\text { Did the report address the } \\
\text { issue of the generalizability } \\
\text { of the findings? }\end{array}$ & $\begin{array}{l}\text { The findings were discussed in } \\
\text { the context of the research } \\
\text { question. } \\
\text { Casual inferences were made } \\
\text { and justified given the results } \\
\text { of the study. } \\
\text { Clinical significance was } \\
\text { discussed and interpretations } \\
\text { were appropriate. } \\
\text { The study did not attempt to } \\
\text { generalize results. } \\
\text { The interpretations of the } \\
\text { authors were consistent with } \\
\text { limitations. }\end{array}$ \\
\hline $\begin{array}{l}\text { Implications/ } \\
\text { recommendations }\end{array}$ & $\begin{array}{l}\text { Did the researchers discuss } \\
\text { the implications of the } \\
\text { study for clinical practice } \\
\text { or further research—and } \\
\text { were those implications } \\
\text { reasonable and complete? }\end{array}$ & $\begin{array}{l}\text { The authors reasonably } \\
\text { identified the need for further } \\
\text { study comparing different } \\
\text { types of music, i.e. nature } \\
\text { sounds, as well as relaxation } \\
\text { exercises to help with } \\
\text { preoperative anxiety. } \\
\text { Recommendations for future } \\
\text { studies included long period of } \\
\text { sessions conducted and } \\
\text { objective measurements } \\
\text { utilized. } \\
\text { The implications made were } \\
\text { reasonable and complete. }\end{array}$ \\
\hline
\end{tabular}




\begin{tabular}{|c|c|c|}
\hline $\begin{array}{l}\text { General Issues } \\
\text { Presentation }\end{array}$ & $\begin{array}{l}\text { - Was the report well- } \\
\text { written, organized, and } \\
\text { sufficiently detailed for } \\
\text { critical analysis? } \\
\text { - In intervention studies, was } \\
\text { a CONSORT flowchart } \\
\text { provided to show the flow } \\
\text { of participants in the study? } \\
\text { Was the report written in a } \\
\text { manner that makes the } \\
\text { findings accessible to } \\
\text { practicing nurses? }\end{array}$ & $\begin{array}{l}\text { The report was easy to follow, } \\
\text { well organized and adequately } \\
\text { detailed. } \\
\text { The report was written in a } \\
\text { manner that is accessible for } \\
\text { practicing nurses. }\end{array}$ \\
\hline Researcher credibility & $\begin{array}{l}\text { Do the researchers' clinical, } \\
\text { substantive, or } \\
\text { methodologic qualifications } \\
\text { and experience enhance } \\
\text { confidence in the findings } \\
\text { and their interpretation? }\end{array}$ & $\begin{array}{l}\text { There was information about } \\
\text { the authors' qualifications and } \\
\text { experience on the first page. }\end{array}$ \\
\hline Summary assessment & 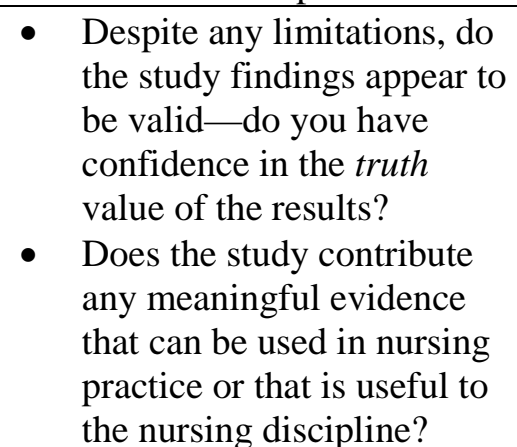 & $\begin{array}{l}\text { The study appeared to be valid } \\
\text { and results had truth value. }\end{array}$ \\
\hline
\end{tabular}




\section{Appendix A-4}

Ghetti, C. M. (2013). Effect of music therapy with emotional-approach coping on Preprocedural Anxiety in Cardiac Catheterization: A Randomized Controlled Trial. Journal of Music Therapy,50(2), 93-122. doi:10.1093/jmt/50.2.93

\begin{tabular}{|c|c|c|}
\hline Aspect of the Report & Critiquing Questions & $\begin{array}{l}\text { Detailed Critiquing } \\
\text { Guidelines }\end{array}$ \\
\hline Title & $\begin{array}{l}\text { Is the title a good one, } \\
\text { succinctly suggesting key } \\
\text { variables and the study } \\
\text { population? }\end{array}$ & $\begin{array}{l}\text { The title clearly identified the } \\
\text { subject, location, and time } \\
\text { frame of the study. }\end{array}$ \\
\hline Abstract & $\begin{array}{l}\text { Did the abstract clearly and } \\
\text { concisely summarize the } \\
\text { main features of the report } \\
\text { (problem, methods, results, } \\
\text { conclusions)? }\end{array}$ & $\begin{array}{l}\text { The abstract thoroughly } \\
\text { outlined all the components of } \\
\text { the study and included } \\
\text { background, objective, } \\
\text { methods, results and } \\
\text { conclusions. }\end{array}$ \\
\hline $\begin{array}{l}\text { Introduction } \\
\text { Statement of the } \\
\text { problem }\end{array}$ & $\begin{array}{l}\text { Was the problem stated } \\
\text { unambiguously, and was it } \\
\text { easy to identify? } \\
\text { - Is the problem statement } \\
\text { build a persuasive argument } \\
\text { for the new study? } \\
\text { - Was there a good match } \\
\text { between the research } \\
\text { problem and the methods } \\
\text { used -that is, was a } \\
\text { quantitative approach } \\
\text { appropriate? }\end{array}$ & $\begin{array}{l}\text { The problem was easily } \\
\text { identified, clear, and suggests a } \\
\text { need for study. } \\
\text { Introduction suggested benefits } \\
\text { of music and its' anxiolytic } \\
\text { effects. It also built a } \\
\text { persuasive argument for } \\
\text { empirical evidence. } \\
\text { A (RCT) randomized, pre- and } \\
\text { posttest experimental design } \\
\text { was the best match for the } \\
\text { research problem. }\end{array}$ \\
\hline $\begin{array}{l}\text { Hypotheses or } \\
\text { research questions }\end{array}$ & $\begin{array}{l}\text { Were research questions } \\
\text { and/or hypotheses explicitly } \\
\text { stated? If not, was their } \\
\text { absence justified? } \\
\text { - Were questions and } \\
\text { hypotheses appropriately } \\
\text { worded, with clear } \\
\text { specification of key } \\
\text { variables and the study } \\
\text { population? } \\
\text { Were the } \\
\text { questions/hypotheses } \\
\text { consistent with existing } \\
\text { knowledge? }\end{array}$ & $\begin{array}{l}\text { The objective of the study was } \\
\text { clearly stated. No hypotheses } \\
\text { were presented or explicitly } \\
\text { stated. } \\
\text { The study included three } \\
\text { research questions. Within } \\
\text { these, key variables and the } \\
\text { study population are easily } \\
\text { identified. Key variables } \\
\text { included psychological, } \\
\text { physiological and procedural } \\
\text { variables. } \\
\text { The research problem was } \\
\text { consistent with existing } \\
\text { knowledge. }\end{array}$ \\
\hline Literature review & $\begin{array}{l}\text { Was the literature review } \\
\text { up-to-date and based } \\
\text { mainly on primary sources? }\end{array}$ & $\begin{array}{l}\text { The literature review was } \\
\text { thorough and succinct, with } \\
\text { good synthesis of evidence on } \\
\text { problem. This section built a } \\
\text { strong basis for new study. }\end{array}$ \\
\hline
\end{tabular}




\begin{tabular}{|c|c|c|}
\hline & $\begin{array}{l}\text { Did the review provide a } \\
\text { state-of-the-art synthesis of } \\
\text { evidence on the problem? } \\
\text { Did the literature review } \\
\text { provide a strong basis for } \\
\text { the new study? }\end{array}$ & $\begin{array}{l}\text { Primary sources were used } \\
\text { with a mix of up-to-date and } \\
\text { not up-to-date sources. }\end{array}$ \\
\hline $\begin{array}{l}\text { Conceptual/theoretical } \\
\text { framework }\end{array}$ & $\begin{array}{l}\text { Were key concepts } \\
\text { adequately defined } \\
\text { conceptually? } \\
\text { - Was a } \\
\text { conceptual/theoretical } \\
\text { framework articulated- } \\
\text { and, if so, was it } \\
\text { appropriate? If not, is the } \\
\text { absence of a framework } \\
\text { justified? } \\
\text { Were the } \\
\text { questions/hypotheses } \\
\text { consistent with the } \\
\text { framework? }\end{array}$ & $\begin{array}{l}\text { The concepts were thoroughly } \\
\text { defined and a conceptual } \\
\text { framework was articulated and } \\
\text { appropriate for the study. } \\
\text { The research questions were } \\
\text { consistent with framework. }\end{array}$ \\
\hline $\begin{array}{l}\text { Method } \\
\text { Protection of human } \\
\text { rights }\end{array}$ & 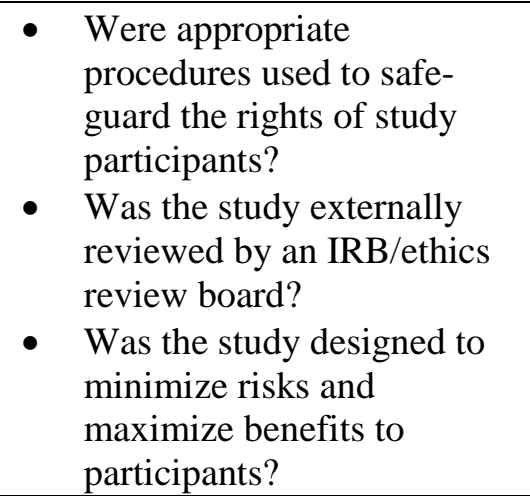 & $\begin{array}{l}\text { There were appropriate } \\
\text { procedures used to safeguard } \\
\text { rights of patients. } \\
\text { The study was approved by the } \\
\text { hospital's IRB and informed } \\
\text { consent was obtained from all } \\
\text { participants. } \\
\text { The study was designed to } \\
\text { minimize risks and maximize } \\
\text { benefits to participants. }\end{array}$ \\
\hline Research design & $\begin{array}{l}\text { Was the most rigorous } \\
\text { design used, given the study } \\
\text { purpose? } \\
\text { Were appropriate } \\
\text { comparisons made to } \\
\text { enhance interpretability of } \\
\text { the findings? } \\
\text { - Was the number of data } \\
\text { collection points } \\
\text { appropriate? } \\
\text { Did the design minimize } \\
\text { biases and threats to the } \\
\text { internal, construct, and } \\
\text { external validity of the } \\
\text { study (e.g., was blinding } \\
\text { used, was attrition } \\
\text { minimized)? }\end{array}$ & $\begin{array}{l}\text { The design used was consistent } \\
\text { with study purpose and most } \\
\text { rigorous design was utilized. } \\
\text { The design was random, but } \\
\text { did not include blinding, which } \\
\text { may contribute to bias. In } \\
\text { addition, the sample size was } \\
\text { limited and included a sole } \\
\text { researcher. It is of note that the } \\
\text { researcher was not blinded, but } \\
\text { the interventional cardiologists } \\
\text { and nurses were blinded. } \\
\text { There were appropriate } \\
\text { comparisons made between } \\
\text { three groups; one group with } \\
\text { music therapy and emotional- } \\
\text { approach coping, one group of } \\
\text { emotional-approach coping } \\
\text { and lastly, a control group. The }\end{array}$ \\
\hline
\end{tabular}




\begin{tabular}{|c|c|c|}
\hline & & $\begin{array}{l}\text { researcher examined } \\
\text { psychological, physiological } \\
\text { and procedural variables to } \\
\text { make comparisons between } \\
\text { groups. } \\
\text { Number of data points were } \\
\text { minimal (N=37). } 41 \% \text { of } \\
\text { individuals who were } \\
\text { approached for the study } \\
\text { declined. }\end{array}$ \\
\hline $\begin{array}{l}\text { Population and } \\
\text { sample }\end{array}$ & $\begin{array}{l}\text { Was the population } \\
\text { identified? Was the sample } \\
\text { described in sufficient } \\
\text { detail? } \\
\text { - Was the best possible } \\
\text { sampling design used to } \\
\text { enhance the sample's } \\
\text { representativeness? Were } \\
\text { sampling biases minimized? } \\
\text { Was the sample size based } \\
\text { on a power analysis? }\end{array}$ & $\begin{array}{l}\text { The population was } \\
\text { extensively identified. } \\
\text { The sample was thoroughly } \\
\text { described. The study was } \\
\text { conducted in a large } \\
\text { Midwestern teaching hospital } \\
\text { and utilized purposive } \\
\text { sampling. A flowchart was } \\
\text { made to show participants' } \\
\text { course throughout the study } \\
\text { and included reasons for } \\
\text { declining the study, as well as } \\
\text { participants not included due } \\
\text { to having a procedure prior to } \\
\text { randomization. } \\
\text { The sample size was based on } \\
\text { a power analysis using a } \\
\text { G*Power } 3.1 \text { and repeated } \\
\text { measures ANOVA. The } \\
\text { sample size was smaller than } \\
\text { projected power analysis and } \\
\text { less than previous studies done } \\
\text { on the same topic. Sample size } \\
\text { was smaller than power } \\
\text { analysis due to time-limitation } \\
\text { and scheduling factors external } \\
\text { to the study and therefore } \\
\text { target sample size was not } \\
\text { achieved. }\end{array}$ \\
\hline $\begin{array}{l}\text { Data collection and } \\
\text { measurement }\end{array}$ & $\begin{array}{l}\text { Were the operational and } \\
\text { conceptual definitions } \\
\text { congruent? } \\
\text { Were key variables } \\
\text { measured using an } \\
\text { appropriate method (e.g., } \\
\text { interviews, observations, } \\
\text { and so on)? } \\
\text { Were specific instruments } \\
\text { adequately described and } \\
\text { were they good choices, }\end{array}$ & $\begin{array}{l}\text { The authors performed the } \\
\text { study how they conceptualized } \\
\text { it. } \\
\text { Key variables were thoroughly } \\
\text { described and broken down } \\
\text { into psychological, } \\
\text { physiological, and procedural } \\
\text { variables. } \\
\text { Key variables were measured } \\
\text { appropriately pre- and post- } \\
\text { tests and included vital signs } \\
\text { and psychological measures }\end{array}$ \\
\hline
\end{tabular}




\begin{tabular}{|c|c|c|}
\hline & $\begin{array}{l}\text { given the study population } \\
\text { and the variables being } \\
\text { studied? } \\
\text { Did the report provide } \\
\text { evidence that the data } \\
\text { collection methods yielded } \\
\text { data that were reliable, } \\
\text { valid and responsive? }\end{array}$ & $\begin{array}{l}\text { i.e. PANAS, pain, coping self- } \\
\text { efficacy, and patient } \\
\text { satisfaction. } \\
\text { Cronbach alpha scores for the } \\
\text { PANAS showed } 0.89 \text { for } \\
\text { positive affect scale and } 0.85 \\
\text { for negative affect scale, } \\
\text { demonstrating adequate } \\
\text { reliability. }\end{array}$ \\
\hline Procedures & $\begin{array}{l}\text { - If there was an intervention, } \\
\text { was it adequately described, } \\
\text { and was it rigorously } \\
\text { developed and } \\
\text { implemented? Did most } \\
\text { participants allocated to the } \\
\text { intervention group actually } \\
\text { receive it? Was there } \\
\text { evidence of intervention } \\
\text { fidelity? } \\
\text { Were data collected in a } \\
\text { manner that minimized } \\
\text { bias? Were the staff who } \\
\text { collected data appropriately } \\
\text { trained? }\end{array}$ & $\begin{array}{l}\text { The intervention was } \\
\text { thoroughly described and } \\
\text { rigorously developed and } \\
\text { implemented. } \\
\text { The study included a total of } \\
37 \text { participants. The group } \\
\text { randomized to MT/EAC group } \\
\text { started with } 15 \text { with } 14 \\
\text { completing measures and } 13 \\
\text { included in analyses. The } \\
\text { group randomized to EAC } \\
\text { started with } 16 \text { and } 14 \\
\text { completed measures and were } \\
\text { included in analyses. The } \\
\text { control group started with } 17 \\
\text { with only } 10 \text { completing } \\
\text { measures and included in } \\
\text { analyses. Reasons for drop out } \\
\text { of each group after } \\
\text { randomization was not } \\
\text { provided. } \\
\text { All interventions were } \\
\text { administered as intended. } \\
\text { It was not noted if the staff } \\
\text { were trained or not. }\end{array}$ \\
\hline Data Analysis & $\begin{array}{l}\text { Were analyses undertaken } \\
\text { to address each research } \\
\text { question or test each } \\
\text { hypothesis? } \\
\text { - Were appropriate statistical } \\
\text { methods used, given the } \\
\text { level of measurement of the } \\
\text { variables, number of groups } \\
\text { being compared, and } \\
\text { assumptions of the texts? } \\
\text { Was a powerful analytic } \\
\text { method used? (e.g., did the } \\
\text { analysis help to control for } \\
\text { confounding variables)? }\end{array}$ & $\begin{array}{l}\text { The data were well analyzed to } \\
\text { address the research question. } \\
\text { The statistical method was } \\
\text { appropriate. } \\
\text { Data were analyzed using } \\
\text { PASW } 18.0 \text { statistical software } \\
\text { package. The level of } \\
\text { significance was set at } \alpha=0.05 \text {, } \\
\text { which is consistent with music } \\
\text { therapy literature. Little's } \\
\text { Missing Completely at } \\
\text { Random (MCAR) chi-square } \\
\text { test was used to evaluate } \\
\text { missing data and categorical } \\
\text { analysis. ANOVA was used to } \\
\text { compare data points. Paired t- } \\
\text { tests were also used in }\end{array}$ \\
\hline
\end{tabular}




\begin{tabular}{|c|c|c|}
\hline & $\begin{array}{l}\text { - Were type I and Type II } \\
\text { errors avoided or } \\
\text { minimized? } \\
\text { - In intervention studies, was } \\
\text { an intention-to-treat } \\
\text { analysis performed? } \\
\text { - Were problems of missing } \\
\text { values evaluated and } \\
\text { adequately addressed? }\end{array}$ & $\begin{array}{l}\text { scenarios that required follow- } \\
\text { up and different time points } \\
\text { among variables. } \\
\text { Intention-to-treat analysis was } \\
\text { not performed. } \\
\text { There were occasional } \\
\text { occurrences of missing data for } \\
\text { physiological parameters } \\
\text { across all treatment groups. }\end{array}$ \\
\hline Findings & $\begin{array}{l}\text { Was information about } \\
\text { statistical significance } \\
\text { presented? Was } \\
\text { information about effect } \\
\text { size and precision of } \\
\text { estimates (confidence } \\
\text { intervals) presented? } \\
\text { - Were the findings } \\
\text { adequately summarized, } \\
\text { with good use of tables and } \\
\text { figures? } \\
\text { Were findings reported in a } \\
\text { manner that facilitates a } \\
\text { meta-analysis, and with } \\
\text { sufficient information } \\
\text { needed for EBP? }\end{array}$ & $\begin{array}{l}\text { Statistical significance was } \\
\text { presented and set at } \alpha=0.05 \text {, } \\
\text { consistent with music therapy } \\
\text { literature. } \\
\text { The findings were well } \\
\text { summarized including three } \\
\text { tables and } 3 \text { figures. } \\
\text { Information was provided } \\
\text { about confidence intervals and } \\
\text { effect size. } \\
\text { The findings reported in a } \\
\text { manner that does not facilitate } \\
\text { a meta-analysis due to small } \\
\text { sample size. }\end{array}$ \\
\hline $\begin{array}{l}\text { Discussion } \\
\text { Interpretation of the } \\
\text { findings }\end{array}$ & $\begin{array}{l}\text { - Were all major findings } \\
\text { interpreted and discussed } \\
\text { within the context of prior } \\
\text { research and/or the study’s } \\
\text { conceptual framework? } \\
\text { - Were casual inferences, if } \\
\text { any, justified? } \\
\text { - Was the issue of clinical } \\
\text { significance discussed? } \\
\text { - Were interpretations well- } \\
\text { founded and consistent with } \\
\text { the study's limitations? } \\
\text { Did the report address the } \\
\text { issue of the generalizability } \\
\text { of the findings? }\end{array}$ & $\begin{array}{l}\text { The findings were discussed in } \\
\text { the context of the research } \\
\text { question. } \\
\text { Casual inferences were made } \\
\text { and justified given the results } \\
\text { of the study. } \\
\text { Clinical significance was } \\
\text { discussed and interpretations } \\
\text { appropriate. } \\
\text { The study did not attempt to } \\
\text { generalize and overtly stated } \\
\text { findings were not generalizable } \\
\text { to areas outside of patients } \\
\text { awaiting cardiac } \\
\text { catheterization. }\end{array}$ \\
\hline $\begin{array}{l}\text { Implications/ } \\
\text { recommendations }\end{array}$ & $\begin{array}{l}\text { Did the researchers discuss } \\
\text { the implications of the } \\
\text { study for clinical practice or } \\
\text { further research-and were } \\
\text { those implications } \\
\text { reasonable and complete? }\end{array}$ & $\begin{array}{l}\text { The author reasonably } \\
\text { identified the need for further } \\
\text { study using a bigger sample } \\
\text { size, possible longer treatment } \\
\text { times, as well as including in- } \\
\text { patient and outpatient patient } \\
\text { populations. } \\
\text { The implications from the } \\
\text { study were reasonable and } \\
\text { complete. }\end{array}$ \\
\hline
\end{tabular}




\begin{tabular}{|c|c|c|}
\hline $\begin{array}{l}\text { General Issues } \\
\text { Presentation }\end{array}$ & $\begin{array}{l}\text { - Was the report well-written, } \\
\text { organized, and sufficiently } \\
\text { detailed for critical } \\
\text { analysis? } \\
\text { - In intervention studies, was } \\
\text { a CONSORT flowchart } \\
\text { provided to show the flow } \\
\text { of participants in the study? } \\
\text { Was the report written in a } \\
\text { manner that makes the } \\
\text { findings accessible to } \\
\text { practicing nurses? }\end{array}$ & $\begin{array}{l}\text { The report was easy to follow, } \\
\text { well organized and very } \\
\text { detailed. } \\
\text { The report was written in a } \\
\text { manner that is accessible for } \\
\text { practicing nurses. }\end{array}$ \\
\hline Researcher credibility & $\begin{array}{l}\text { Do the researchers' clinical, } \\
\text { substantive, or } \\
\text { methodologic qualifications } \\
\text { and experience enhance } \\
\text { confidence in the findings } \\
\text { and their interpretation? }\end{array}$ & $\begin{array}{l}\text { There was information about } \\
\text { the author's qualifications and } \\
\text { experience on the first page. }\end{array}$ \\
\hline Summary assessment & 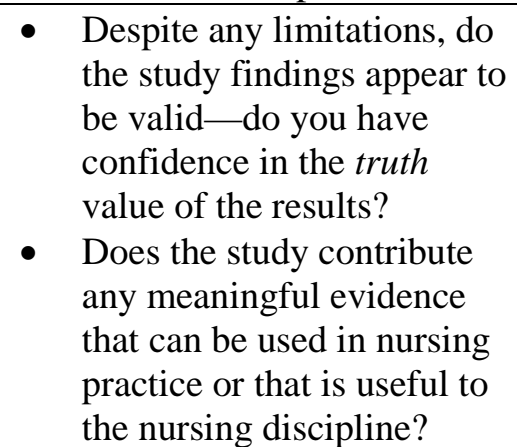 & $\begin{array}{l}\text { The study appears to be valid } \\
\text { and appears to have truth value } \\
\text { of the results. } \\
\text { The study identifies a problem } \\
\text { and shows a need for further } \\
\text { research with a bigger sample } \\
\text { size, stating the results of this } \\
\text { study are only preliminary. }\end{array}$ \\
\hline
\end{tabular}




\section{Appendix A-5}

Kovac, M. (2014). Music interventions for the treatment of preoperative anxiety. Journal of Consumer Health on the Internet,18(2), 193-201. doi:10.1080/15398285.2014.902282

\begin{tabular}{|c|c|}
\hline Critiquing Questions & Critique Responses \\
\hline $\begin{array}{l}\text { 1. Is the review thorough-does it include all } \\
\text { major studies on the topic? Does it include } \\
\text { recent research (studies published within } \\
\text { previous 2-3 years)? Are studies from } \\
\text { other related disciplines included, if } \\
\text { appropriate? }\end{array}$ & $\begin{array}{l}\text { The review was thorough and included } \\
\text { all major studies related to topic. Recent } \\
\text { research was included and relative to } \\
\text { publication date. Studies from other } \\
\text { disciplines i.e. music were included in } \\
\text { brief detail. }\end{array}$ \\
\hline $\begin{array}{l}\text { 2. Does the review rely mainly on primary } \\
\text { source research articles? Are the articles } \\
\text { from peer-reviewed journals? }\end{array}$ & $\begin{array}{l}\text { The review used primary source research } \\
\text { articles and from peer-reviewed sources. }\end{array}$ \\
\hline $\begin{array}{l}\text { 3. Is the review merely a summary of existing } \\
\text { work, or does it critically appraise and } \\
\text { compare key studies? Does the review } \\
\text { identify important gaps in the literature? }\end{array}$ & $\begin{array}{l}\text { The review was primarily a summary of } \\
\text { existing work, but adequately compared } \\
\text { key studies and brought concepts } \\
\text { together. It also identified gaps in the } \\
\text { literature. }\end{array}$ \\
\hline $\begin{array}{l}\text { 4. Is the review well organized? Is the } \\
\text { development of ideas clear? }\end{array}$ & $\begin{array}{l}\text { The review was adequately organized, } \\
\text { but would benefit from section headers. } \\
\text { The development of ideas was adequate } \\
\text { and sequential for ease of the reader. }\end{array}$ \\
\hline $\begin{array}{l}\text { Does the review use appropriate language, } \\
\text { suggesting the tentativeness of prior } \\
\text { findings? Is the review objective? Does } \\
\text { the author paraphrase, or is there an } \\
\text { overreliance on quotes from original } \\
\text { sources? }\end{array}$ & $\begin{array}{l}\text { The review used appropriate language } \\
\text { and appeared to be objective. There was } \\
\text { minimal use of direct quotes. However, } \\
\text { there was a substantial amount of citing } \\
\text { noted from original sources to report } \\
\text { results of previous studies done. }\end{array}$ \\
\hline $\begin{array}{l}\text { 6. If the review is part of a research report for } \\
\text { a new study, does the review support the } \\
\text { need for the study? }\end{array}$ & $\begin{array}{l}\text { This review was not part of a new study, } \\
\text { but did support the need for the study. }\end{array}$ \\
\hline $\begin{array}{l}\text { 7. If it is a review designed to summarize } \\
\text { evidence for clinical practice, does the } \\
\text { review draw reasonable conclusions about } \\
\text { practice implications? }\end{array}$ & $\begin{array}{l}\text { The review drew very reasonable } \\
\text { conclusions about practice implications } \\
\text { which were made clear to reader. }\end{array}$ \\
\hline
\end{tabular}




\section{Appendix A-6}

Kushnir, J. et al. (2012). Coping with preoperative anxiety in cesarean section: physiological, cognitive, and emotional effects of listening to favorite music. Retrieved from http://onlinelibrary.wiley.com/doi/10.1111/j.1523-536X.2012.00532.x/abstract

\begin{tabular}{|c|c|c|}
\hline Aspect of the Report & Critiquing Questions & $\begin{array}{l}\text { Detailed Critiquing } \\
\text { Guidelines }\end{array}$ \\
\hline Title & $\begin{array}{l}\text { Is the title a good one, } \\
\text { succinctly suggesting key } \\
\text { variables and the study } \\
\text { population? }\end{array}$ & $\begin{array}{l}\text { The title clearly identified the } \\
\text { subject, location, and time } \\
\text { frame of the study. }\end{array}$ \\
\hline Abstract & $\begin{array}{l}\text { Did the abstract clearly and } \\
\text { concisely summarize the } \\
\text { main features of the report } \\
\text { (problem, methods, results, } \\
\text { conclusions)? }\end{array}$ & $\begin{array}{l}\text { The abstract was descriptive } \\
\text { and included background, } \\
\text { methods, results and a } \\
\text { conclusion section. }\end{array}$ \\
\hline $\begin{array}{l}\text { Introduction } \\
\text { Statement of the } \\
\text { problem }\end{array}$ & $\begin{array}{l}\text { - Was the problem stated } \\
\text { unambiguously, and was it } \\
\text { easy to identify? } \\
\text { - Is the problem statement } \\
\text { build a persuasive argument } \\
\text { for the new study? } \\
\text { - Was there a good match } \\
\text { between the research } \\
\text { problem and the methods } \\
\text { used -that is, was a } \\
\text { quantitative approach } \\
\text { appropriate? }\end{array}$ & $\begin{array}{l}\text { The problem was easily } \\
\text { identified, clear, and suggested } \\
\text { a need for study. The authors } \\
\text { built a persuasive argument for } \\
\text { a new study, as most of the } \\
\text { studies done in past were } \\
\text { related to perioperative and } \\
\text { postoperative time periods and } \\
\text { focused on negative outcomes, } \\
\text { rather than positive ones. } \\
\text { Relevance to nursing clinical } \\
\text { practice was clearly stated. } \\
\text { A pre- and posttest } \\
\text { experimental design with } \\
\text { random assignment was } \\
\text { appropriate for research } \\
\text { problem. }\end{array}$ \\
\hline $\begin{array}{l}\text { Hypotheses or } \\
\text { research questions }\end{array}$ & $\begin{array}{l}\text { - Were research questions } \\
\text { and/or hypotheses explicitly } \\
\text { stated? If not, was their } \\
\text { absence justified? } \\
\text { - Were questions and } \\
\text { hypotheses appropriately } \\
\text { worded, with clear } \\
\text { specification of key } \\
\text { variables and the study } \\
\text { population? } \\
\text { Were the } \\
\text { questions/hypotheses } \\
\text { consistent with existing } \\
\text { knowledge? }\end{array}$ & $\begin{array}{l}\text { The research question was not } \\
\text { stated. However, the aim of the } \\
\text { study was stated in the abstract } \\
\text { and the beginning of the study. } \\
\text { The hypothesis was clearly } \\
\text { stated, but lacked specification } \\
\text { of study population. The key } \\
\text { variables identified included } \\
\text { mood and threat perception } \\
\text { and vital signs. } \\
\text { The hypothesis was consistent } \\
\text { with existing knowledge. }\end{array}$ \\
\hline
\end{tabular}




\begin{tabular}{|c|c|c|}
\hline Literature review & $\begin{array}{l}\text { Was the literature review } \\
\text { up-to-date and based } \\
\text { mainly on primary sources? } \\
\text { Did the review provide a } \\
\text { state-of-the-art synthesis of } \\
\text { evidence on the problem? } \\
\text { Did the literature review } \\
\text { provide a strong basis for } \\
\text { the new study? }\end{array}$ & $\begin{array}{l}\text { The literature review discussed } \\
\text { previous studies done and built } \\
\text { a strong basis for a new study, } \\
\text { using both subjective and } \\
\text { objective measures. The } \\
\text { literature review was thorough } \\
\text { and provided good synthesis of } \\
\text { evidence on problem. }\end{array}$ \\
\hline $\begin{array}{l}\text { Conceptual/theoretical } \\
\text { framework }\end{array}$ & $\begin{array}{l}\text { - Were key concepts } \\
\text { adequately defined } \\
\text { conceptually? } \\
\text { - Was a } \\
\text { conceptual/theoretical } \\
\text { framework articulated- } \\
\text { and, if so, was it } \\
\text { appropriate? If not, is the } \\
\text { absence of a framework } \\
\text { justified? } \\
\text { Were the } \\
\text { questions/hypotheses } \\
\text { consistent with the } \\
\text { framework? }\end{array}$ & $\begin{array}{l}\text { There was no theoretical } \\
\text { framework identified. } \\
\text { Concepts were adequately } \\
\text { defined and thorough. }\end{array}$ \\
\hline $\begin{array}{l}\text { Method } \\
\text { Protection of human } \\
\text { rights }\end{array}$ & $\begin{array}{l}\text { Were appropriate } \\
\text { procedures used to safe- } \\
\text { guard the rights of study } \\
\text { participants? } \\
\text { - Was the study externally } \\
\text { reviewed by an IRB/ethics } \\
\text { review board? } \\
\text { - Was the study designed to } \\
\text { minimize risks and } \\
\text { maximize benefits to } \\
\text { participants? }\end{array}$ & $\begin{array}{l}\text { No information was provided } \\
\text { regarding safe-guarding the } \\
\text { rights of study participants. } \\
\text { However, the authors stated } \\
\text { that it was approved by the } \\
\text { ethics (Helsinki) committee. } \\
\text { The study was designed to } \\
\text { minimize risks and maximize } \\
\text { benefits to the participants. } \\
\text { Participants in active labor or } \\
\text { medical complications, or } \\
\text { women with babies with life- } \\
\text { threatening problems, were not } \\
\text { eligible to participate in the } \\
\text { study. }\end{array}$ \\
\hline Research design & $\begin{array}{l}\text { - Was the most rigorous } \\
\text { design used, given the study } \\
\text { purpose? } \\
\text { - Were appropriate } \\
\text { comparisons made to } \\
\text { enhance interpretability of } \\
\text { the findings? } \\
\text { - Was the number of data } \\
\text { collection points } \\
\text { appropriate? } \\
\text { Did the design minimize } \\
\text { biases and threats to the }\end{array}$ & $\begin{array}{l}\text { The design used was consistent } \\
\text { with study goals and purpose, } \\
\text { using a qualitative and } \\
\text { quantitative approach. } \\
\text { Randomization was used with } \\
\text { regard to participants, but not } \\
\text { random to investigators, which } \\
\text { may contribute to bias } \\
\text { Appropriate comparisons were } \\
\text { made. } \\
\text { Number of data points were } \\
\text { adequate }(\mathrm{N}=60) \text { and }\end{array}$ \\
\hline
\end{tabular}




\begin{tabular}{|c|c|c|}
\hline & $\begin{array}{l}\text { internal, construct, and } \\
\text { external validity of the } \\
\text { study (e.g., was blinding } \\
\text { used, was attrition } \\
\text { minimized)? }\end{array}$ & $\begin{array}{l}\text { comparable to other studies } \\
\text { using a similar topic. }\end{array}$ \\
\hline $\begin{array}{l}\text { Population and } \\
\text { sample }\end{array}$ & $\begin{array}{l}\text { - Was the population } \\
\text { identified? Was the sample } \\
\text { described in sufficient } \\
\text { detail? } \\
\text { Was the best possible } \\
\text { sampling design used to } \\
\text { enhance the sample's } \\
\text { representativeness? Were } \\
\text { sampling biases minimized? } \\
\text { Was the sample size based } \\
\text { on a power analysis? }\end{array}$ & $\begin{array}{l}\text { The population was identified } \\
\text { in the first section of the study. } \\
\text { The sample was adequately } \\
\text { identified and described in } \\
\text { sufficient detail. The study was } \\
\text { conducted in a regional } \\
\text { hospital in Israel. } \\
\text { No flowchart was made for } \\
\text { identifying patient inclusion or } \\
\text { exclusion data. However, } \\
\text { exclusion criteria were } \\
\text { included. Bias included small } \\
\text { sample size and that the study } \\
\text { used a non-blinded approach. } \\
\text { The sample size was not based } \\
\text { on a power analysis and was } \\
\text { small in comparison to other } \\
\text { studies performed on the same } \\
\text { topic. }\end{array}$ \\
\hline $\begin{array}{l}\text { Data collection and } \\
\text { measurement }\end{array}$ & $\begin{array}{l}\text { - Were the operational and } \\
\text { conceptual definitions } \\
\text { congruent? } \\
\text { Were key variables } \\
\text { measured using an } \\
\text { appropriate method (e.g., } \\
\text { interviews, observations, } \\
\text { and so on)? } \\
\text { Were specific instruments } \\
\text { adequately described and } \\
\text { were they good choices, } \\
\text { given the study population } \\
\text { and the variables being } \\
\text { studied? } \\
\text { Did the report provide } \\
\text { evidence that the data } \\
\text { collection methods yielded } \\
\text { data that were reliable, } \\
\text { valid and responsive? }\end{array}$ & $\begin{array}{l}\text { The authors performed the } \\
\text { study how they conceptualized } \\
\text { it. } \\
\text { Key variables were measured } \\
\text { appropriately. Variables } \\
\text { included a mood state scale, } \\
\text { perceived threat of surgery } \\
\text { scale and vital signs. } \\
\text { The scales to measure } \\
\text { variables were adequately } \\
\text { described. } \\
\text { The study provided evidence } \\
\text { that the Mood State Scale and } \\
\text { the Perceived Threat of } \\
\text { Surgery Scale are reliable } \\
\text { scales and included the } \\
\text { Cronbach alpha scores. The } \\
\text { Cronbach alpha score for the } \\
\text { negative and positive moods } \\
\text { state scales were } 0.86 \text { and } 0.77 \\
\text { respectively. The Cronbach } \\
\text { alpha score for the perceived } \\
\text { threat scale was } 0.87 \text {. }\end{array}$ \\
\hline Procedures & $\begin{array}{l}\text { If there was an intervention, } \\
\text { was it adequately described, } \\
\text { and was it rigorously }\end{array}$ & $\begin{array}{l}\text { The intervention was } \\
\text { thoroughly described. } \\
\text { A total of } 60 \text { women were } \\
\text { included in the study. There }\end{array}$ \\
\hline
\end{tabular}




\begin{tabular}{|c|c|c|}
\hline & $\begin{array}{l}\text { developed and } \\
\text { implemented? Did most } \\
\text { participants allocated to the } \\
\text { intervention group actually } \\
\text { receive it? Was there } \\
\text { evidence of intervention } \\
\text { fidelity? } \\
\text { - Were data collected in a } \\
\text { manner that minimized } \\
\text { bias? Were the staff who } \\
\text { collected data appropriately } \\
\text { trained? }\end{array}$ & $\begin{array}{l}\text { were } 28 \text { women in the } \\
\text { experimental group and } 32 \text { in } \\
\text { the control group. It was not } \\
\text { stated if the participants } \\
\text { actually received the } \\
\text { designated intervention, as } \\
\text { well as if there were any drop } \\
\text { outs at any point in time during } \\
\text { the study for any reason. } \\
\text { It was not noted if the staff } \\
\text { were trained or not. }\end{array}$ \\
\hline Data Analysis & $\begin{array}{l}\text { - Were analyses undertaken } \\
\text { to address each research } \\
\text { question or test each } \\
\text { hypothesis? } \\
\text { - } \quad \text { Were appropriate statistical } \\
\text { methods used, given the } \\
\text { level of measurement of the } \\
\text { variables, number of groups } \\
\text { being compared, and } \\
\text { assumptions of the texts? } \\
\text { - Was a powerful analytic } \\
\text { method used? (e.g., did the } \\
\text { analysis help to control for } \\
\text { confounding variables)? } \\
\text { Were type I and Type II } \\
\text { errors avoided or } \\
\text { minimized? } \\
\text { In intervention studies, was } \\
\text { an intention-to-treat } \\
\text { analysis performed? } \\
\text { Were problems of missing } \\
\text { values evaluated and } \\
\text { adequately addressed? }\end{array}$ & $\begin{array}{l}\text { The data were well analyzed to } \\
\text { address the research question. } \\
\text { The statistical method was } \\
\text { appropriate. } \\
\text { Powerful analytic method was } \\
\text { used. } \\
\text { Discrete analysis of covariance } \\
\text { (ANCOVA) was performed for } \\
\text { each outcome measure. } \\
\text { Potential confounding } \\
\text { variables were identified. } \\
\text { Intention-to-treat analysis was } \\
\text { not performed. } \\
\text { No missing values were } \\
\text { identified, nor were they } \\
\text { addressed. }\end{array}$ \\
\hline Findings & $\begin{array}{l}\text { - Was information about } \\
\text { statistical significance } \\
\text { presented? Was } \\
\text { information about effect } \\
\text { size and precision of } \\
\text { estimates (confidence } \\
\text { intervals) presented? } \\
\text { - Were the findings } \\
\text { adequately summarized, } \\
\text { with good use of tables and } \\
\text { figures? } \\
\text { Were findings reported in a } \\
\text { manner that facilitates a } \\
\text { meta-analysis, and with }\end{array}$ & $\begin{array}{l}\text { Statistical significance and } \\
\text { information about effect size } \\
\text { were presented. No confidence } \\
\text { intervals were provided. } \\
\text { The findings were summarized } \\
\text { in two tables and one figure } \\
\text { showing subjective measures. }\end{array}$ \\
\hline
\end{tabular}




\begin{tabular}{|c|c|c|}
\hline & $\begin{array}{l}\text { sufficient information } \\
\text { needed for EBP? }\end{array}$ & \\
\hline $\begin{array}{l}\text { Discussion } \\
\text { Interpretation of the } \\
\text { findings }\end{array}$ & $\begin{array}{l}\text { - Were all major findings } \\
\text { interpreted and discussed } \\
\text { within the context of prior } \\
\text { research and/or the study's } \\
\text { conceptual framework? } \\
\text { - Were casual inferences, if } \\
\text { any, justified? } \\
\text { - Was the issue of clinical } \\
\text { significance discussed? } \\
\text { - Were interpretations well- } \\
\text { founded and consistent with } \\
\text { the study's limitations? } \\
\text { Did the report address the } \\
\text { issue of the generalizability } \\
\text { of the findings? }\end{array}$ & $\begin{array}{l}\text { The findings were discussed in } \\
\text { the context of the research } \\
\text { question. } \\
\text { Casual inferences were made } \\
\text { and justified given the results } \\
\text { of the study. } \\
\text { Clinical significance was } \\
\text { discussed and interpretations } \\
\text { were appropriate. } \\
\text { The study did not attempt to } \\
\text { generalize and overtly stated it } \\
\text { is not generalizable due to } \\
\text { relatively small sample size, as } \\
\text { well as possible contribution of } \\
\text { bias from nonblinding of } \\
\text { investigators. }\end{array}$ \\
\hline $\begin{array}{l}\text { Implications/ } \\
\text { recommendations }\end{array}$ & $\begin{array}{l}\text { Did the researchers discuss } \\
\text { the implications of the } \\
\text { study for clinical practice or } \\
\text { further research-and were } \\
\text { those implications } \\
\text { reasonable and complete? }\end{array}$ & $\begin{array}{l}\text { The study identified a problem } \\
\text { and showed a need for further } \\
\text { research on whether the option } \\
\text { of choosing music has an } \\
\text { effect on anxiety levels and } \\
\text { also if different types of music } \\
\text { have different influences on } \\
\text { stress. }\end{array}$ \\
\hline $\begin{array}{l}\text { General Issues } \\
\text { Presentation }\end{array}$ & $\begin{array}{l}\text { - Was the report well-written, } \\
\text { organized, and sufficiently } \\
\text { detailed for critical } \\
\text { analysis? } \\
\text { - In intervention studies, was } \\
\text { a CONSORT flowchart } \\
\text { provided to show the flow } \\
\text { of participants in the study? } \\
\text { Was the report written in a } \\
\text { manner that makes the } \\
\text { findings accessible to } \\
\text { practicing nurses? }\end{array}$ & $\begin{array}{l}\text { The report was easy to follow, } \\
\text { adequately organized and very } \\
\text { detailed. } \\
\text { The report was written in a } \\
\text { manner that is accessible for } \\
\text { practicing nurses. }\end{array}$ \\
\hline Researcher credibility & $\begin{array}{l}\text { - Do the researchers' clinical, } \\
\text { substantive, or } \\
\text { methodologic qualifications } \\
\text { and experience enhance } \\
\text { confidence in the findings } \\
\text { and their interpretation? }\end{array}$ & $\begin{array}{l}\text { There was information about } \\
\text { the authors' qualifications and } \\
\text { experience on the first page } \\
\text { with a footnote in detail. }\end{array}$ \\
\hline Summary assessment & $\begin{array}{l}\text { Despite any limitations, do } \\
\text { the study findings appear to } \\
\text { be valid-do you have } \\
\text { confidence in the truth } \\
\text { value of the results? }\end{array}$ & $\begin{array}{l}\text { The study appeared to be valid } \\
\text { and to have truth value. The } \\
\text { authors acknowledged } \\
\text { limitations and potential bias. }\end{array}$ \\
\hline
\end{tabular}




\begin{tabular}{|l|l|l|}
\hline & $\begin{array}{l}\text { Does the study contribute } \\
\text { any meaningful evidence } \\
\text { that can be used in nursing } \\
\text { practice or that is useful to } \\
\text { the nursing discipline? }\end{array}$ & $\begin{array}{l}\text { The study contributes } \\
\text { meaningful evidence that can } \\
\text { be using in nursing practice. }\end{array}$ \\
\hline
\end{tabular}




\section{Appendix A-7}

Labrague, L. J. \& Mcenroe-Petitte, D. M. (2014). Influence of music on preoperative anxiety and physiologic parameters in women undergoing gynecologic surgery. Clinical Nursing Research,25(2), 157-173. doi:10.1177/1054773814544168

\begin{tabular}{|c|c|c|}
\hline Aspect of the Report & Critiquing Questions & $\begin{array}{l}\text { Detailed Critiquing } \\
\text { Guidelines }\end{array}$ \\
\hline Title & $\begin{array}{l}\text { Is the title a good one, } \\
\text { succinctly suggesting key } \\
\text { variables and the study } \\
\text { population? }\end{array}$ & $\begin{array}{l}\text { The title clearly identified the } \\
\text { subject, location, and time } \\
\text { frame of the study. }\end{array}$ \\
\hline Abstract & $\begin{array}{l}\text { Did the abstract clearly and } \\
\text { concisely summarize the } \\
\text { main features of the report } \\
\text { (problem, methods, results, } \\
\text { conclusions)? }\end{array}$ & $\begin{array}{l}\text { The abstract thoroughly } \\
\text { outlined all the components of } \\
\text { the study. }\end{array}$ \\
\hline $\begin{array}{l}\text { Introduction } \\
\text { Statement of the } \\
\text { problem }\end{array}$ & $\begin{array}{l}\text { Was the problem stated } \\
\text { unambiguously, and was it } \\
\text { easy to identify? } \\
\text { Is the problem statement } \\
\text { build a persuasive argument } \\
\text { for the new study? } \\
\text { - Was there a good match } \\
\text { between the research } \\
\text { problem and the methods } \\
\text { used -that is, was a } \\
\text { quantitative approach } \\
\text { appropriate? }\end{array}$ & $\begin{array}{l}\text { The problem was easily } \\
\text { identified, clear, and suggested } \\
\text { a need for a new study. } \\
\text { Introduction suggested benefits } \\
\text { of music and its anxiolytic } \\
\text { effects and built a persuasive } \\
\text { argument for empirical } \\
\text { evidence. } \\
\text { Relevance to nursing clinical } \\
\text { practice was clearly stated. } \\
\text { A pre- and post-test } \\
\text { experimental design with } \\
\text { nonrandom assignment was } \\
\text { appropriate for research } \\
\text { problem. }\end{array}$ \\
\hline $\begin{array}{l}\text { Hypotheses or } \\
\text { research questions }\end{array}$ & $\begin{array}{l}\text { - Were research questions } \\
\text { and/or hypotheses explicitly } \\
\text { stated? If not, was their } \\
\text { absence justified? } \\
\text { - Were questions and } \\
\text { hypotheses appropriately } \\
\text { worded, with clear } \\
\text { specification of key } \\
\text { variables and the study } \\
\text { population? } \\
\text { Were the } \\
\text { questions/hypotheses } \\
\text { consistent with existing } \\
\text { knowledge? }\end{array}$ & $\begin{array}{l}\text { The aim of the study was } \\
\text { stated in the abstract, as well as } \\
\text { in a separate section following } \\
\text { the background, which clearly } \\
\text { identified the topic. There was } \\
\text { no research question or } \\
\text { hypothesis explicitly stated in } \\
\text { the study. }\end{array}$ \\
\hline Literature review & $\begin{array}{l}\text { Was the literature review } \\
\text { up-to-date and based } \\
\text { mainly on primary sources? }\end{array}$ & $\begin{array}{l}\text { The literature review provided } \\
\text { up-to-date and mainly primary } \\
\text { sources. The literature review } \\
\text { provided a state-of-the-art }\end{array}$ \\
\hline
\end{tabular}




\begin{tabular}{|c|c|c|}
\hline & $\begin{array}{l}\text { Did the review provide a } \\
\text { state-of-the-art synthesis of } \\
\text { evidence on the problem? } \\
\text { Did the literature review } \\
\text { provide a strong basis for } \\
\text { the new study? }\end{array}$ & $\begin{array}{l}\text { synthesis of evidence on the } \\
\text { problem and strong basis for a } \\
\text { new study. }\end{array}$ \\
\hline $\begin{array}{l}\text { Conceptual/theoretical } \\
\text { framework }\end{array}$ & $\begin{array}{l}\text { Were key concepts } \\
\text { adequately defined } \\
\text { conceptually? } \\
\text { Was a } \\
\text { conceptual/theoretical } \\
\text { framework articulated- } \\
\text { and, if so, was it } \\
\text { appropriate? If not, is the } \\
\text { absence of a framework } \\
\text { justified? } \\
\text { Were the } \\
\text { questions/hypotheses } \\
\text { consistent with the } \\
\text { framework? }\end{array}$ & $\begin{array}{l}\text { There was no theoretical } \\
\text { framework identified. } \\
\text { Concepts were adequately and } \\
\text { thoroughly defined. }\end{array}$ \\
\hline $\begin{array}{l}\text { Method } \\
\text { Protection of human } \\
\text { rights }\end{array}$ & $\begin{array}{l}\text { - Were appropriate } \\
\text { procedures used to safe- } \\
\text { guard the rights of study } \\
\text { participants? } \\
\text { - Was the study externally } \\
\text { reviewed by an IRB/ethics } \\
\text { review board? } \\
\text { Was the study designed to } \\
\text { minimize risks and } \\
\text { maximize benefits to } \\
\text { participants? }\end{array}$ & $\begin{array}{l}\text { Appropriate procedures were } \\
\text { used to safeguard rights of } \\
\text { patients. } \\
\text { The study was approved by } \\
\text { ethical committee prior to } \\
\text { initiation. Informed consent } \\
\text { was obtained from all } \\
\text { participants. } \\
\text { The study was designed to } \\
\text { minimize risks and maximize } \\
\text { benefits to participants. }\end{array}$ \\
\hline Research design & $\begin{array}{l}\text { Was the most rigorous } \\
\text { design used, given the } \\
\text { study purpose? } \\
\text { Were appropriate } \\
\text { comparisons made to } \\
\text { enhance interpretability of } \\
\text { the findings? } \\
\text { - Was the number of data } \\
\text { collection points } \\
\text { appropriate? } \\
\text { Did the design minimize } \\
\text { biases and threats to the } \\
\text { internal, construct, and } \\
\text { external validity of the } \\
\text { study (e.g., was blinding } \\
\text { used, was attrition } \\
\text { minimized)? }\end{array}$ & $\begin{array}{l}\text { The design used was consistent } \\
\text { with study goals and purpose, } \\
\text { but was not the most rigorous. } \\
\text { Design was nonrandom and no } \\
\text { blinding was used, both of } \\
\text { which contribute to bias. } \\
\text { Appropriate comparisons were } \\
\text { made between the control } \\
\text { group and experimental group. } \\
\text { A table was provided to } \\
\text { examine the difference } \\
\text { between these two groups and } \\
\text { different parameters studied, } \\
\text { i.e. STAI scores, blood } \\
\text { pressure, pulse rate, and } \\
\text { respiratory rate. } \\
\text { Number of data points } \\
\text { adequate, N=97. }\end{array}$ \\
\hline
\end{tabular}




\begin{tabular}{|c|c|c|}
\hline $\begin{array}{l}\text { Population and } \\
\text { sample }\end{array}$ & $\begin{array}{l}\text { Was the population } \\
\text { identified? Was the sample } \\
\text { described in sufficient } \\
\text { detail? } \\
\text { - Was the best possible } \\
\text { sampling design used to } \\
\text { enhance the sample's } \\
\text { representativeness? Were } \\
\text { sampling biases } \\
\text { minimized? } \\
\text { Was the sample size based } \\
\text { on a power analysis? }\end{array}$ & $\begin{array}{l}\text { The population of women } \\
\text { experiencing high levels of } \\
\text { anxiety was identified } \\
\text { thoroughly in the introduction. } \\
\text { The sample size was } \\
\text { adequately identified and } \\
\text { described as being recruited } \\
\text { from a 150-bed capacity } \\
\text { government hospital in a } \\
\text { purposive sampling method. A } \\
\text { flowchart was provided to } \\
\text { identify patient early } \\
\text { termination and encompassed } \\
\text { reasons for not including, i.e. } \\
\text { hearing problems and refusal } \\
\text { by participants. } \\
\text { The design was adequate, but } \\
\text { several biases are present. The } \\
\text { participants were not } \\
\text { randomized, the researchers } \\
\text { were not blinded and } \\
\text { participants were from one } \\
\text { hospital. } \\
\text { The sample size was not based } \\
\text { on a power analysis. Sample } \\
\text { size was adequate (N=97) and } \\
\text { comparable to previous studies } \\
\text { performed on same topic. }\end{array}$ \\
\hline $\begin{array}{l}\text { Data collection and } \\
\text { measurement }\end{array}$ & $\begin{array}{l}\text { - Were the operational and } \\
\text { conceptual definitions } \\
\text { congruent? } \\
\text { Were key variables } \\
\text { measured using an } \\
\text { appropriate method (e.g., } \\
\text { interviews, observations, } \\
\text { and so on)? } \\
\text { - Were specific instruments } \\
\text { adequately described and } \\
\text { were they good choices, } \\
\text { given the study population } \\
\text { and the variables being } \\
\text { studied? } \\
\text { Did the report provide } \\
\text { evidence that the data } \\
\text { collection methods yielded } \\
\text { data that were reliable, } \\
\text { valid and responsive? }\end{array}$ & $\begin{array}{l}\text { The authors performed the } \\
\text { study how they conceptualized } \\
\text { it. } \\
\text { Key variables were measured } \\
\text { appropriately using STAI } \\
\text { scores and vital signs. } \\
\text { The method in which the } \\
\text { findings were analyzed was } \\
\text { well described and a good } \\
\text { choice. } \\
\text { The report provided evidence } \\
\text { that methods (STAI) were } \\
\text { highly valid and reliable. It } \\
\text { was translated and discussed } \\
\text { with a group of experts to } \\
\text { determine content validity as } \\
\text { well. Cronbach’s alpha of } \\
\text { STAI was reported at } 0.92 \text {. }\end{array}$ \\
\hline Procedures & $\begin{array}{l}\text { If there was an intervention, } \\
\text { was it adequately described, } \\
\text { and was it rigorously }\end{array}$ & $\begin{array}{l}\text { Intervention was adequately } \\
\text { described and rigorously } \\
\text { developed and implemented. }\end{array}$ \\
\hline
\end{tabular}




\begin{tabular}{|c|c|c|}
\hline & $\begin{array}{l}\text { developed and } \\
\text { implemented? Did most } \\
\text { participants allocated to the } \\
\text { intervention group actually } \\
\text { receive it? Was there } \\
\text { evidence of intervention } \\
\text { fidelity? } \\
\text { - Were data collected in a } \\
\text { manner that minimized } \\
\text { bias? Were the staff who } \\
\text { collected data appropriately } \\
\text { trained? }\end{array}$ & $\begin{array}{l}\text { All } 49 \text { participants in control } \\
\text { group remained in that group. } \\
\text { All } 48 \text { participants in music } \\
\text { group actually received music. } \\
\text { All interventions were } \\
\text { administered as intended. } \\
\text { Data were collected in manner } \\
\text { with minimal bias. It was not } \\
\text { noted if staff were trained or } \\
\text { not. }\end{array}$ \\
\hline Data Analysis & $\begin{array}{l}\text { - Were analyses undertaken } \\
\text { to address each research } \\
\text { question or test each } \\
\text { hypothesis? } \\
\text { - } \quad \text { Were appropriate statistical } \\
\text { methods used, given the } \\
\text { level of measurement of the } \\
\text { variables, number of groups } \\
\text { being compared, and } \\
\text { assumptions of the texts? } \\
\text { - Was a powerful analytic } \\
\text { method used? (e.g., did the } \\
\text { analysis help to control for } \\
\text { confounding variables)? } \\
\text { Were type I and Type II } \\
\text { errors avoided or } \\
\text { minimized? } \\
\text { In intervention studies, was } \\
\text { an intention-to-treat } \\
\text { analysis performed? } \\
\text { Were problems of missing } \\
\text { values evaluated and } \\
\text { adequately addressed? }\end{array}$ & $\begin{array}{l}\text { The data were appropriately } \\
\text { analyzed to address the } \\
\text { research question. } \\
\text { The statistical method was } \\
\text { appropriate. } \\
\text { Descriptive statistics were used } \\
\text { to quantify demographical } \\
\text { information. Chi-square } \\
\text { analysis/Fisher's exact test } \\
\text { were used to test homogeneity } \\
\text { and normality of two groups. } \\
\text { Paired t-tests were used to } \\
\text { examine significant differences } \\
\text { between pre- and posttest } \\
\text { STAI, as well as physiologic } \\
\text { parameters for the groups. } \\
\text { Intention-to-treat analysis was } \\
\text { not performed. } \\
\text { No missing values were } \\
\text { identified, nor were they } \\
\text { addressed. }\end{array}$ \\
\hline Findings & $\begin{array}{l}\text { - Was information about } \\
\text { statistical significance } \\
\text { presented? Was } \\
\text { information about effect } \\
\text { size and precision of } \\
\text { estimates (confidence } \\
\text { intervals) presented? } \\
\text { - Were the findings } \\
\text { adequately summarized, } \\
\text { with good use of tables and } \\
\text { figures? } \\
\text { Were findings reported in a } \\
\text { manner that facilitates a } \\
\text { meta-analysis, and with }\end{array}$ & $\begin{array}{l}\text { Statistical significance was } \\
\text { presented and set at } p<0.05 \text {. } \\
\text { The findings were well } \\
\text { summarized including } \\
\text { presentation of three tables. } \\
\text { Information was provided } \\
\text { about confidence intervals } \\
\text { regarding posttest scores. } \\
\text { The findings suggested the } \\
\text { need for further studies on } \\
\text { music interventions on } \\
\text { preoperative anxiety in the } \\
\text { women population. }\end{array}$ \\
\hline
\end{tabular}




\begin{tabular}{|c|c|c|}
\hline & $\begin{array}{l}\text { sufficient information } \\
\text { needed for EBP? }\end{array}$ & \\
\hline $\begin{array}{l}\text { Discussion } \\
\text { Interpretation of the } \\
\text { findings }\end{array}$ & $\begin{array}{l}\text { - Were all major findings } \\
\text { interpreted and discussed } \\
\text { within the context of prior } \\
\text { research and/or the study’s } \\
\text { conceptual framework? } \\
\text { - Were casual inferences, if } \\
\text { any, justified? } \\
\text { - Was the issue of clinical } \\
\text { significance discussed? } \\
\text { Were interpretations well- } \\
\text { founded and consistent with } \\
\text { the study's limitations? } \\
\text { - Did the report address the } \\
\text { issue of the generalizability } \\
\text { of the findings? }\end{array}$ & $\begin{array}{l}\text { The findings were discussed in } \\
\text { the context of the research } \\
\text { question. } \\
\text { Casual inferences were made } \\
\text { and justified given the results } \\
\text { of the study. } \\
\text { Clinical significance was } \\
\text { discussed and interpretations } \\
\text { appropriate. } \\
\text { The study did not attempt to } \\
\text { generalize and overtly stated } \\
\text { that findings were s not } \\
\text { generalizable to areas outside } \\
\text { of women in gynecologic } \\
\text { surgery. }\end{array}$ \\
\hline $\begin{array}{l}\text { Implications/ } \\
\text { recommendations }\end{array}$ & $\begin{array}{l}\text { - Did the researchers discuss } \\
\text { the implications of the } \\
\text { study for clinical practice or } \\
\text { further research—and were } \\
\text { those implications } \\
\text { reasonable and complete? }\end{array}$ & $\begin{array}{l}\text { The authors reasonably } \\
\text { identified the need for further } \\
\text { study using different types of } \\
\text { music with varied listening } \\
\text { duration time. They also } \\
\text { suggested considering self- } \\
\text { selected music and varied } \\
\text { populations. The objective } \\
\text { would be to determine the } \\
\text { extent to which music would } \\
\text { result in maximum anxiety } \\
\text { reduction. }\end{array}$ \\
\hline $\begin{array}{l}\text { General Issues } \\
\text { Presentation }\end{array}$ & $\begin{array}{l}\text { - Was the report well-written, } \\
\text { organized, and sufficiently } \\
\text { detailed for critical } \\
\text { analysis? } \\
\text { - In intervention studies, was } \\
\text { a CONSORT flowchart } \\
\text { provided to show the flow } \\
\text { of participants in the study? } \\
\text { - Was the report written in a } \\
\text { manner that makes the } \\
\text { findings accessible to } \\
\text { practicing nurses? }\end{array}$ & $\begin{array}{l}\text { The report was easy to follow, } \\
\text { well organized and very } \\
\text { detailed. } \\
\text { It was written in a manner that } \\
\text { is accessible for practicing } \\
\text { nurses. }\end{array}$ \\
\hline Researcher credibility & $\begin{array}{l}\text { - Do the researchers' clinical, } \\
\text { substantive, or } \\
\text { methodologic qualifications } \\
\text { and experience enhance } \\
\text { confidence in the findings } \\
\text { and their interpretation? }\end{array}$ & $\begin{array}{l}\text { There was information about } \\
\text { the authors' qualifications and } \\
\text { experience on the first page } \\
\text { with a footnote, as well as the } \\
\text { last page with a section titled } \\
\text { author biographies. }\end{array}$ \\
\hline Summary assessment & $\begin{array}{l}\text { - Despite any limitations, do } \\
\text { the study findings appear to }\end{array}$ & $\begin{array}{l}\text { Study findings appeared to be } \\
\text { valid and to have truth value. }\end{array}$ \\
\hline
\end{tabular}




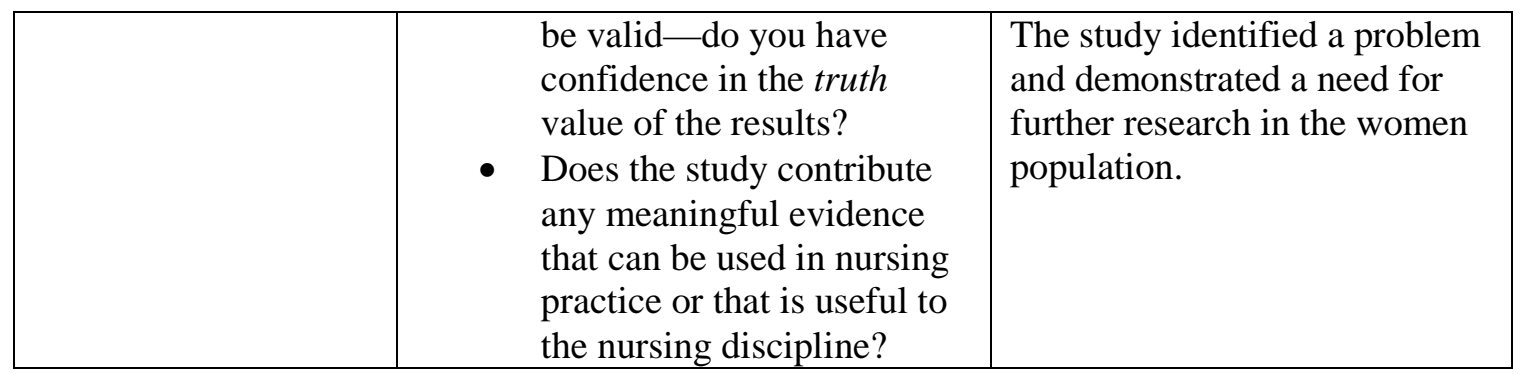




\section{Appendix A-8}

Lee, K. et al. (2011). Effectiveness of different music-playing devices for reducing preoperative anxiety: A clinical control study. International Journal of Nursing Studies,48(10), 11801187. doi:10.1016/j.ijnurstu.2011.04.001

\begin{tabular}{|c|c|c|}
\hline Aspect of the Report & Critiquing Questions & $\begin{array}{l}\text { Detailed Critiquing } \\
\text { Guidelines }\end{array}$ \\
\hline Title & $\begin{array}{l}\text { Is the title a good one, } \\
\text { succinctly suggesting key } \\
\text { variables and the study } \\
\text { population? }\end{array}$ & $\begin{array}{l}\text { The title clearly identified the } \\
\text { subject, location, and key } \\
\text { variables of the study. }\end{array}$ \\
\hline Abstract & $\begin{array}{l}\text { Did the abstract clearly and } \\
\text { concisely summarize the } \\
\text { main features of the report } \\
\text { (problem, methods, results, } \\
\text { conclusions)? }\end{array}$ & $\begin{array}{l}\text { The abstract thoroughly } \\
\text { outlined all the components of } \\
\text { the study and included } \\
\text { background, objectives, } \\
\text { design, setting, participants, } \\
\text { methods, results, conclusion } \\
\text { and relevance to clinical } \\
\text { practice. }\end{array}$ \\
\hline $\begin{array}{l}\text { Introduction } \\
\text { Statement of the } \\
\text { problem }\end{array}$ & $\begin{array}{l}\text { Was the problem stated } \\
\text { unambiguously, and was it } \\
\text { easy to identify? } \\
\text { Is the problem statement } \\
\text { build a persuasive argument } \\
\text { for the new study? } \\
\text { - Was there a good match } \\
\text { between the research } \\
\text { problem and the methods } \\
\text { used -that is, was a } \\
\text { quantitative approach } \\
\text { appropriate? }\end{array}$ & $\begin{array}{l}\text { The problem was easily } \\
\text { identified, clear, and suggested } \\
\text { a need for study. } \\
\text { The study built a persuasive } \\
\text { argument for a new study and } \\
\text { presented information about } \\
\text { what is already known about } \\
\text { the topic and what the article } \\
\text { added to this body of } \\
\text { knowledge. } \\
\text { Relevance to nursing clinical } \\
\text { practice was clearly stated. } \\
\text { A three-group randomized } \\
\text { controlled trial was conducted, } \\
\text { but lacks a pretest-posttest } \\
\text { comparison analysis piece. }\end{array}$ \\
\hline $\begin{array}{l}\text { Hypotheses or } \\
\text { research questions }\end{array}$ & $\begin{array}{l}\text { - Were research questions } \\
\text { and/or hypotheses explicitly } \\
\text { stated? If not, was their } \\
\text { absence justified? } \\
\text { - Were questions and } \\
\text { hypotheses appropriately } \\
\text { worded, with clear } \\
\text { specification of key } \\
\text { variables and the study } \\
\text { population? } \\
\text { Were the } \\
\text { questions/hypotheses } \\
\text { consistent with existing } \\
\text { knowledge? }\end{array}$ & $\begin{array}{l}\text { The objective of the study was } \\
\text { explicitly stated. A proposed } \\
\text { hypothesis was not included in } \\
\text { the study. } \\
\text { The research aim was } \\
\text { consistent with existing } \\
\text { knowledge. }\end{array}$ \\
\hline
\end{tabular}




\begin{tabular}{|c|c|c|}
\hline Literature review & $\begin{array}{l}\text { Was the literature review } \\
\text { up-to-date and based mainly } \\
\text { on primary sources? } \\
\text { Did the review provide a } \\
\text { state-of-the-art synthesis of } \\
\text { evidence on the problem? } \\
\text { - Did the literature review } \\
\text { provide a strong basis for } \\
\text { the new study? }\end{array}$ & $\begin{array}{l}\text { The literature review discussed } \\
\text { previous studies and built a } \\
\text { strong basis for a new study } \\
\text { using broadcasted music vs } \\
\text { headphones and the impact on } \\
\text { preoperative anxiety. The } \\
\text { literature review was brief, but } \\
\text { provided a good synthesis of } \\
\text { evidence on the problem. }\end{array}$ \\
\hline $\begin{array}{l}\text { Conceptual/theoretical } \\
\text { framework }\end{array}$ & $\begin{array}{l}\text { - Were key concepts } \\
\text { adequately defined } \\
\text { conceptually? } \\
\text { - Was a } \\
\text { conceptual/theoretical } \\
\text { framework articulated- } \\
\text { and, if so, was it } \\
\text { appropriate? If not, is the } \\
\text { absence of a framework } \\
\text { justified? } \\
\text { Were the } \\
\text { questions/hypotheses } \\
\text { consistent with the } \\
\text { framework? }\end{array}$ & $\begin{array}{l}\text { There was no theoretical } \\
\text { framework identified. } \\
\text { Concepts were adequately } \\
\text { defined. }\end{array}$ \\
\hline $\begin{array}{l}\text { Method } \\
\text { Protection of human } \\
\text { rights }\end{array}$ & $\begin{array}{l}\text { Were appropriate } \\
\text { procedures used to safe- } \\
\text { guard the rights of study } \\
\text { participants? } \\
\text { - Was the study externally } \\
\text { reviewed by an IRB/ethics } \\
\text { review board? } \\
\text { Was the study designed to } \\
\text { minimize risks and } \\
\text { maximize benefits to } \\
\text { participants? }\end{array}$ & $\begin{array}{l}\text { Appropriate procedures were } \\
\text { used to safeguard rights of } \\
\text { patients. } \\
\text { Study was approved by the } \\
\text { Institutional Review Board of } \\
\text { the teaching hospital located in } \\
\text { Taiwan with the approved } \\
\text { code included in the study. } \\
\text { Written informed consent was } \\
\text { obtained from all participants. } \\
\text { The study was designed to } \\
\text { minimize risks and maximize } \\
\text { benefits to participants. }\end{array}$ \\
\hline Research design & $\begin{array}{l}\text { - Was the most rigorous } \\
\text { design used, given the study } \\
\text { purpose? } \\
\text { Were appropriate } \\
\text { comparisons made to } \\
\text { enhance interpretability of } \\
\text { the findings? } \\
\text { - Was the number of data } \\
\text { collection points } \\
\text { appropriate? } \\
\text { Did the design minimize } \\
\text { biases and threats to the } \\
\text { internal, construct, and }\end{array}$ & $\begin{array}{l}\text { The design used was consistent } \\
\text { with study goals and purpose. } \\
\text { A random table was applied to } \\
\text { divide numbers } 1-30 \text { into three } \\
\text { groups to determine each day } \\
\text { of the month to be one of the } \\
\text { three groups. } \\
\text { The design lacked pretest- } \\
\text { posttest comparisons, therefor } \\
\text { there is no baseline to } \\
\text { reference data back to. The } \\
\text { three groups included a control } \\
\text { group, a headphone group and }\end{array}$ \\
\hline
\end{tabular}




\begin{tabular}{|c|c|c|}
\hline & $\begin{array}{l}\text { external validity of the } \\
\text { study (e.g., was blinding } \\
\text { used, was attrition } \\
\text { minimized)? }\end{array}$ & $\begin{array}{l}\text { a broadcast group. The study } \\
\text { included a control group to } \\
\text { offset lack of pretest, as a } \\
\text { reference for comparison of } \\
\text { the headphone and broadcast } \\
\text { groups. } \\
\text { The study was designed to } \\
\text { minimize bias and threats to } \\
\text { internal validity. It was not } \\
\text { noted if blinding was used. } \\
\text { The number of data points } \\
\text { were adequate, } N=167 \text {. }\end{array}$ \\
\hline $\begin{array}{l}\text { Population and } \\
\text { sample }\end{array}$ & $\begin{array}{l}\text { - Was the population } \\
\text { identified? Was the sample } \\
\text { described in sufficient } \\
\text { detail? } \\
\text { - Was the best possible } \\
\text { sampling design used to } \\
\text { enhance the sample's } \\
\text { representativeness? Were } \\
\text { sampling biases minimized? } \\
\text { Was the sample size based } \\
\text { on a power analysis? }\end{array}$ & $\begin{array}{l}\text { The population was adequately } \\
\text { identified in the introduction. } \\
\text { The sample was described in } \\
\text { sufficient detail. The sample } \\
\text { size was G power software. } \\
\text { The study considered an } \\
\text { attrition rate of } 30 \% \text { due to } \\
\text { short stay in the waiting area, a } \\
\text { sample size of about } 50 \text { was } \\
\text { set. } \\
\text { A flowchart was provided and } \\
\text { showed participants' refusal } \\
\text { and number of completed } \\
\text { participants. } \\
\text { Sample size (N=167) was } \\
\text { adequate based on the power } \\
\text { analysis. }\end{array}$ \\
\hline $\begin{array}{l}\text { Data collection and } \\
\text { measurement }\end{array}$ & $\begin{array}{l}\text { Were the operational and } \\
\text { conceptual definitions } \\
\text { congruent? } \\
\text { Were key variables } \\
\text { measured using an } \\
\text { appropriate method (e.g., } \\
\text { interviews, observations, } \\
\text { and so on)? } \\
\text { - Were specific instruments } \\
\text { adequately described and } \\
\text { were they good choices, } \\
\text { given the study population } \\
\text { and the variables being } \\
\text { studied? } \\
\text { Did the report provide } \\
\text { evidence that the data } \\
\text { collection methods yielded } \\
\text { data that were reliable, valid } \\
\text { and responsive? }\end{array}$ & $\begin{array}{l}\text { The authors performed the } \\
\text { study as they conceptualized it. } \\
\text { Key variables were measured } \\
\text { appropriately using VAS } \\
\text { scores, heart rate variability } \\
\text { (HRV) and were appropriate } \\
\text { for this study. } \\
\text { The report provided evidence } \\
\text { for VAS scale as a valid } \\
\text { measurement of anxiety. No } \\
\text { evidence was provided for } \\
\text { validity or reliability of HRV. }\end{array}$ \\
\hline
\end{tabular}




\begin{tabular}{|c|c|c|}
\hline Procedures & $\begin{array}{l}\text { - If there was an intervention, } \\
\text { was it adequately described, } \\
\text { and was it rigorously } \\
\text { developed and } \\
\text { implemented? Did most } \\
\text { participants allocated to the } \\
\text { intervention group actually } \\
\text { receive it? Was there } \\
\text { evidence of intervention } \\
\text { fidelity? } \\
\text { Were data collected in a } \\
\text { manner that minimized } \\
\text { bias? Were the staff who } \\
\text { collected data appropriately } \\
\text { trained? }\end{array}$ & $\begin{array}{l}\text { Intervention was adequately } \\
\text { described and rigorously } \\
\text { developed and implemented. } \\
66 \text { out of } 66 \text { randomly } \\
\text { assigned to the broadcast } \\
\text { group were included in } \\
\text { analysis. } 53 \text { out of } 58 \\
\text { randomly to control group } \\
\text { were included in analysis. } \\
\text { Lastly, } 48 \text { out of } 56 \text { randomly } \\
\text { assigned to headphone group } \\
\text { were included in analysis. } \\
\text { Dropouts and reasons were } \\
\text { included in the flowchart } \\
\text { All interventions were } \\
\text { administered as intended. } \\
\text { Data were collected in manner } \\
\text { consistent with minimal bias, } \\
\text { with a randomized technique. } \\
\text { No blinding was used. It was } \\
\text { not noted if staff were trained. }\end{array}$ \\
\hline Data Analysis & $\begin{array}{l}\text { - Were analyses undertaken } \\
\text { to address each research } \\
\text { question or test each } \\
\text { hypothesis? } \\
\text { - Were appropriate statistical } \\
\text { methods used, given the } \\
\text { level of measurement of the } \\
\text { variables, number of groups } \\
\text { being compared, and } \\
\text { assumptions of the texts? } \\
\text { Was a powerful analytic } \\
\text { method used? (e.g., did the } \\
\text { analysis help to control for } \\
\text { confounding variables)? } \\
\text { Were type I and Type II } \\
\text { errors avoided or } \\
\text { minimized? } \\
\text { In intervention studies, was } \\
\text { an intention-to-treat } \\
\text { analysis performed? } \\
\text { Were problems of missing } \\
\text { values evaluated and } \\
\text { adequately addressed? }\end{array}$ & $\begin{array}{l}\text { The data were appropriately } \\
\text { analyzed to address the } \\
\text { research question. } \\
\text { The statistical method was } \\
\text { appropriate. } \\
\text { Powerful analytic method was } \\
\text { not used. } \\
\text { Intention-to-treat analysis was } \\
\text { performed to analyze data. } \\
\text { Data were analyzed with SPSS } \\
\text { 15.0. A Chi-squared test was } \\
\text { used to evaluate differences } \\
\text { between the three groups. A } \\
\text { one-way ANOVA test was } \\
\text { used to look at differences } \\
\text { between VAS and HRV } \\
\text { parameters among the three } \\
\text { groups. When a significant } \\
\text { difference was identified, a } \\
\text { Scheffe test was done to } \\
\text { examine the paired difference. } \\
\text { Incomplete values were } \\
\text { identified and excluded from } \\
\text { analysis. }\end{array}$ \\
\hline Findings & $\begin{array}{l}\text { Was information about } \\
\text { statistical significance } \\
\text { presented? Was } \\
\text { information about effect } \\
\text { size and precision of }\end{array}$ & $\begin{array}{l}\text { Information regarding } \\
\text { statistical tests was presented. } \\
\text { There were no confidence } \\
\text { intervals included in analysis. }\end{array}$ \\
\hline
\end{tabular}




\begin{tabular}{|c|c|c|}
\hline & $\begin{array}{l}\text { estimates (confidence } \\
\text { intervals) presented? } \\
\text { - Were the findings } \\
\text { adequately summarized, } \\
\text { with good use of tables and } \\
\text { figures? } \\
\text { - Were findings reported in a } \\
\text { manner that facilitates a } \\
\text { meta-analysis, and with } \\
\text { sufficient information } \\
\text { needed for EBP? }\end{array}$ & $\begin{array}{l}\text { The findings were well } \\
\text { summarized including three } \\
\text { tables. } \\
\text { Due to lack of pretest-posttest } \\
\text { evaluation, the study does not } \\
\text { facilitate a meta-analysis. }\end{array}$ \\
\hline $\begin{array}{l}\text { Discussion } \\
\text { Interpretation of the } \\
\text { findings }\end{array}$ & $\begin{array}{l}\text { - Were all major findings } \\
\text { interpreted and discussed } \\
\text { within the context of prior } \\
\text { research and/or the study’s } \\
\text { conceptual framework? } \\
\text { - Were casual inferences, if } \\
\text { any, justified? } \\
\text { - Was the issue of clinical } \\
\text { significance discussed? } \\
\text { Were interpretations well- } \\
\text { founded and consistent with } \\
\text { the study’s limitations? } \\
\text { Did the report address the } \\
\text { issue of the generalizability } \\
\text { of the findings? }\end{array}$ & $\begin{array}{l}\text { The findings were discussed in } \\
\text { the context of the research } \\
\text { question. } \\
\text { Casual inferences were made } \\
\text { and justified given the results } \\
\text { of the study. } \\
\text { Clinical significance was } \\
\text { discussed and interpretations } \\
\text { appropriate. } \\
\text { The study did not attempt to } \\
\text { generalize. The study stated } \\
\text { that findings may provide a } \\
\text { basis for future studies } \\
\text { regarding evaluating music } \\
\text { therapy in different surgical } \\
\text { procedures. Limitations were } \\
\text { overtly stated and reasonable. }\end{array}$ \\
\hline $\begin{array}{l}\text { Implications/ } \\
\text { recommendations }\end{array}$ & $\begin{array}{l}\text { Did the researchers discuss } \\
\text { the implications of the } \\
\text { study for clinical practice or } \\
\text { further research-and were } \\
\text { those implications } \\
\text { reasonable and complete? }\end{array}$ & $\begin{array}{l}\text { The authors reasonably } \\
\text { identified the need for future } \\
\text { studies to evaluate the lasting } \\
\text { effects of music lowering } \\
\text { anxiety levels during the } \\
\text { intraoperative and } \\
\text { postoperative stages of } \\
\text { surgery. }\end{array}$ \\
\hline $\begin{array}{l}\text { General Issues } \\
\text { Presentation }\end{array}$ & $\begin{array}{l}\text { - Was the report well-written, } \\
\text { organized, and sufficiently } \\
\text { detailed for critical } \\
\text { analysis? } \\
\text { - In intervention studies, was } \\
\text { a CONSORT flowchart } \\
\text { provided to show the flow } \\
\text { of participants in the study? } \\
\text { - Was the report written in a } \\
\text { manner that makes the } \\
\text { findings accessible to } \\
\text { practicing nurses? }\end{array}$ & $\begin{array}{l}\text { The report was easy to follow, } \\
\text { well organized and very } \\
\text { detailed. } \\
\text { It was written in a manner that } \\
\text { is accessible for practicing } \\
\text { nurses. }\end{array}$ \\
\hline Researcher credibility & $\begin{array}{l}\text { - Do the researchers' clinical, } \\
\text { substantive, or }\end{array}$ & $\begin{array}{l}\text { Information was provided on } \\
\text { the first page about the }\end{array}$ \\
\hline
\end{tabular}




\begin{tabular}{|l|c|l|}
\hline & $\begin{array}{l}\text { methodologic qualifications } \\
\text { and experience enhance } \\
\text { confidence in the findings } \\
\text { and their interpretation? }\end{array}$ & $\begin{array}{l}\text { authors' qualifications, in } \\
\text { addition to contact information } \\
\text { via email, telephone or fax. }\end{array}$ \\
\hline Summary assessment & $\begin{array}{l}\text { Despite any limitations, do } \\
\text { the study findings appear to } \\
\text { be valid-do you have } \\
\text { confidence in the truth } \\
\text { value of the results? } \\
\text { Does the study contribute } \\
\text { any meaningful evidence } \\
\text { that can be used in nursing } \\
\text { practice or that is useful to } \\
\text { the nursing discipline? }\end{array}$ & $\begin{array}{l}\text { The study appeared to be valid } \\
\text { and results appeared to have } \\
\text { truth value. } \\
\text { The study identified a problem } \\
\text { and showed a need for further } \\
\text { research regarding the } \\
\text { therapeutic value of music } \\
\text { therapy, particularly in the } \\
\text { preoperative setting. }\end{array}$ \\
\hline
\end{tabular}




\section{Appendix A-9}

Ni, C. et al. (2011). Minimising preoperative anxiety with music for day surgery patients- a randomised clinical trial. Journal of Clinical Nursing, 21(5-6), 620-625. Doi:10.1111/j.1365-2702.2010.03466.x

\begin{tabular}{|c|c|c|}
\hline Aspect of the Report & Critiquing Questions & $\begin{array}{l}\text { Detailed Critiquing } \\
\text { Guidelines }\end{array}$ \\
\hline Title & $\begin{array}{l}\text { Is the title a good one, } \\
\text { succinctly suggesting key } \\
\text { variables and the study } \\
\text { population? }\end{array}$ & $\begin{array}{l}\text { The title clearly identified the } \\
\text { subject, location, and time } \\
\text { frame of the study. }\end{array}$ \\
\hline Abstract & $\begin{array}{l}\text { Did the abstract clearly and } \\
\text { concisely summarize the } \\
\text { main features of the report } \\
\text { (problem, methods, results, } \\
\text { conclusions)? }\end{array}$ & $\begin{array}{l}\text { The abstract thoroughly } \\
\text { outlined all the components of } \\
\text { the study. }\end{array}$ \\
\hline $\begin{array}{l}\text { Introduction } \\
\text { Statement of the } \\
\text { problem }\end{array}$ & $\begin{array}{l}\text { Was the problem stated } \\
\text { unambiguously, and was it } \\
\text { easy to identify? } \\
\text { Is the problem statement } \\
\text { build a persuasive } \\
\text { argument for the new } \\
\text { study? } \\
\text { - Was there a good match } \\
\text { between the research } \\
\text { problem and the methods } \\
\text { used -that is, was a } \\
\text { quantitative approach } \\
\text { appropriate? }\end{array}$ & $\begin{array}{l}\text { The problem was easily } \\
\text { identified, clear, and suggested } \\
\text { a need for further study. } \\
\text { Introduction suggested benefits } \\
\text { of music and its anxiolytic } \\
\text { effects and introduces prior } \\
\text { research with mixed results. } \\
\text { The authors presented a } \\
\text { persuasive argument for new } \\
\text { study. The relevance to nursing } \\
\text { clinical practice was clearly } \\
\text { stated. } \\
\text { A randomized controlled } \\
\text { clinical trial was completed } \\
\text { and quantitatively looked at } \\
\text { anxiety levels based on a scale, } \\
\text { as well as vital signs. }\end{array}$ \\
\hline $\begin{array}{l}\text { Hypotheses or } \\
\text { research questions }\end{array}$ & $\begin{array}{l}\text { Were research questions } \\
\text { and/or hypotheses } \\
\text { explicitly stated? If not, } \\
\text { was their absence justified? } \\
\text { Were questions and } \\
\text { hypotheses appropriately } \\
\text { worded, with clear } \\
\text { specification of key } \\
\text { variables and the study } \\
\text { population? } \\
\text { Were the } \\
\text { questions/hypotheses } \\
\text { consistent with existing } \\
\text { knowledge? }\end{array}$ & $\begin{array}{l}\text { There was no research question } \\
\text { explicitly stated; however, the } \\
\text { aim and objective of the study } \\
\text { were clearly stated in the } \\
\text { abstract as well as the } \\
\text { introduction section. There was } \\
\text { a hypothesis that was explicitly } \\
\text { stated. }\end{array}$ \\
\hline
\end{tabular}




\begin{tabular}{|c|c|c|}
\hline Literature review & $\begin{array}{l}\text { Was the literature review } \\
\text { up-to-date and based } \\
\text { mainly on primary sources? } \\
\text { Did the review provide a } \\
\text { state-of-the-art synthesis of } \\
\text { evidence on the problem? } \\
\text { Did the literature review } \\
\text { provide a strong basis for } \\
\text { the new study? }\end{array}$ & $\begin{array}{l}\text { A limited literature review was } \\
\text { presented in the background } \\
\text { section. The author presented a } \\
\text { strong basis for a new study } \\
\text { with an attempt to overcome } \\
\text { limitations of other studies, i.e. } \\
\text { by using a randomized } \\
\text { controlled study design. }\end{array}$ \\
\hline $\begin{array}{l}\text { Conceptual/theoretical } \\
\text { framework }\end{array}$ & $\begin{array}{l}\text { - Were key concepts } \\
\text { adequately defined } \\
\text { conceptually? } \\
\text { - Was a } \\
\text { conceptual/theoretical } \\
\text { framework articulated- } \\
\text { and, if so, was it } \\
\text { appropriate? If not, is the } \\
\text { absence of a framework } \\
\text { justified? } \\
\text { Were the } \\
\text { questions/hypotheses } \\
\text { consistent with the } \\
\text { framework? }\end{array}$ & $\begin{array}{l}\text { There was no theoretical } \\
\text { framework identified. } \\
\text { Concepts were adequately } \\
\text { defined but could have been } \\
\text { more thorough. }\end{array}$ \\
\hline $\begin{array}{l}\text { Method } \\
\text { Protection of human } \\
\text { rights }\end{array}$ & 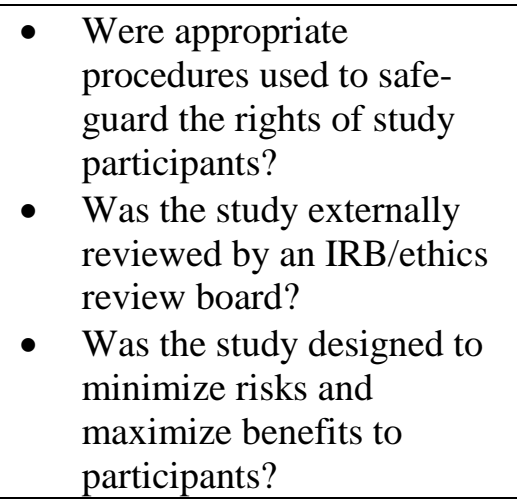 & $\begin{array}{l}\text { Appropriate procedures were } \\
\text { used to safeguard rights of } \\
\text { patients. } \\
\text { Study was reviewed by IRB. } \\
\text { Informed consent was obtained } \\
\text { from all participants. } \\
\text { Study was designed to } \\
\text { minimize risks and maximize } \\
\text { benefits to participants. }\end{array}$ \\
\hline Research design & $\begin{array}{l}\text { - Was the most rigorous } \\
\text { design used, given the } \\
\text { study purpose? } \\
\text { - Were appropriate } \\
\text { comparisons made to } \\
\text { enhance interpretability of } \\
\text { the findings? } \\
\text { - Was the number of data } \\
\text { collection points } \\
\text { appropriate? } \\
\text { Did the design minimize } \\
\text { biases and threats to the } \\
\text { internal, construct, and } \\
\text { external validity of the } \\
\text { study (e.g., was blinding }\end{array}$ & $\begin{array}{l}\text { The most rigorous design, a } \\
\text { RCT, was used and was } \\
\text { consistent with study goals and } \\
\text { purpose. } \\
\text { Appropriate comparisons were } \\
\text { made. } \\
\text { Randomization was used, but } \\
\text { blinding was not which could } \\
\text { contribute to bias. } \\
\text { The design attempted to } \\
\text { minimize bias by using } \\
\text { objective outcome measures. } \\
\text { The factors that could have } \\
\text { contributed to bias included the } \\
\text { individual(s) collecting data } \\
\text { were not blinded. }\end{array}$ \\
\hline
\end{tabular}




\begin{tabular}{|c|c|c|}
\hline & $\begin{array}{l}\text { used, was attrition } \\
\text { minimized)? }\end{array}$ & $\begin{array}{l}\text { Participants were placed in two } \\
\text { groups: a music group, with } \\
\text { music delivered by earphones; } \\
\text { and a control group, without } \\
\text { music for } 20 \text { minutes before } \\
\text { surgery. }\end{array}$ \\
\hline $\begin{array}{l}\text { Population and } \\
\text { sample }\end{array}$ & $\begin{array}{l}\text { - Was the population } \\
\text { identified? Was the sample } \\
\text { described in sufficient } \\
\text { detail? } \\
\text { - Was the best possible } \\
\text { sampling design used to } \\
\text { enhance the sample's } \\
\text { representativeness? Were } \\
\text { sampling biases } \\
\text { minimized? } \\
\text { Was the sample size based } \\
\text { on a power analysis? }\end{array}$ & $\begin{array}{l}\text { The population was adequately } \\
\text { identified in the introduction } \\
\text { section. The sample was } \\
\text { described in sufficient detail. A } \\
\text { table was provided regarding } \\
\text { demographic information and } \\
\text { baseline characteristics. } \\
\text { A flowchart was presented for } \\
\text { subjects who completed the } \\
\text { study and the number of } \\
\text { participants that withdrew from } \\
\text { the study. } \\
\text { The sample design was random } \\
\text { and from } 1 \text { hospital over } 3 \\
\text { years. The study attempted to } \\
\text { minimize sampling biases by } \\
\text { using a randomized approach } \\
\text { and objective outcome } \\
\text { measures. } \\
\text { The sample size was not based } \\
\text { on a power analysis but } \\
\text { appeared to be adequate } \\
\text { (N=172). }\end{array}$ \\
\hline $\begin{array}{l}\text { Data collection and } \\
\text { measurement }\end{array}$ & $\begin{array}{l}\text { Were the operational and } \\
\text { conceptual definitions } \\
\text { congruent? } \\
\text { Were key variables } \\
\text { measured using an } \\
\text { appropriate method (e.g., } \\
\text { interviews, observations, } \\
\text { and so on)? } \\
\text { - Were specific instruments } \\
\text { adequately described and } \\
\text { were they good choices, } \\
\text { given the study population } \\
\text { and the variables being } \\
\text { studied? } \\
\text { Did the report provide } \\
\text { evidence that the data } \\
\text { collection methods yielded } \\
\text { data that were reliable, } \\
\text { valid and responsive? }\end{array}$ & $\begin{array}{l}\text { The authors performed the } \\
\text { study how they conceptualized } \\
\text { it. } \\
\text { Key variables were measured } \\
\text { appropriately using STAI } \\
\text { scores and vital signs. } \\
\text { The method in which the } \\
\text { findings were analyzed was } \\
\text { well described. Evidence that } \\
\text { measure (STAI) was } \\
\text { previously validated and } \\
\text { exhibited high internal } \\
\text { consistency (0.90-0.94) was } \\
\text { presented. }\end{array}$ \\
\hline Procedures & $\begin{array}{ll} & \text { If there was an } \\
& \text { intervention, was it }\end{array}$ & $\begin{array}{l}\text { The intervention was } \\
\text { adequately described and }\end{array}$ \\
\hline
\end{tabular}




\begin{tabular}{|c|c|c|}
\hline & $\begin{array}{l}\text { adequately described, and } \\
\text { was it rigorously developed } \\
\text { and implemented? Did } \\
\text { most participants allocated } \\
\text { to the intervention group } \\
\text { actually receive it? Was } \\
\text { there evidence of } \\
\text { intervention fidelity? } \\
\text { - Were data collected in a } \\
\text { manner that minimized } \\
\text { bias? Were the staff who } \\
\text { collected data appropriately } \\
\text { trained? }\end{array}$ & $\begin{array}{l}\text { rigorously developed and } \\
\text { implemented. } \\
\text { All } 86 \text { participants in control } \\
\text { group remained in that group. } \\
\text { All } 86 \text { participants in music } \\
\text { group actually received music. } \\
\text { All interventions were } \\
\text { administered as intended. The } \\
\text { data were collected by } \\
\text { individuals who were not } \\
\text { blinded. These individuals } \\
\text { were not noted to be trained or } \\
\text { not. The authors acknowledged } \\
\text { that the use of an interviewer } \\
\text { who administered the } \\
\text { questionnaire may have } \\
\text { introduced positive bias in } \\
\text { scores. However, this } \\
\text { interviewer collected data for } \\
\text { both control and music group. }\end{array}$ \\
\hline Data Analysis & $\begin{array}{l}\text { Were analyses undertaken } \\
\text { to address each research } \\
\text { question or test each } \\
\text { hypothesis? } \\
\text { - Were appropriate statistical } \\
\text { methods used, given the } \\
\text { level of measurement of the } \\
\text { variables, number of groups } \\
\text { being compared, and } \\
\text { assumptions of the texts? } \\
\text { Was a powerful analytic } \\
\text { method used? (e.g., did the } \\
\text { analysis help to control for } \\
\text { confounding variables)? } \\
\text { Were type I and Type II } \\
\text { errors avoided or } \\
\text { minimized? } \\
\text { In intervention studies, was } \\
\text { an intention-to-treat } \\
\text { analysis performed? } \\
\text { Were problems of missing } \\
\text { values evaluated and } \\
\text { adequately addressed? }\end{array}$ & $\begin{array}{l}\text { The data were analyzed to } \\
\text { address the research question. } \\
\text { The statistical method was } \\
\text { appropriate. } \\
\text { Independent two-sample t-tests } \\
\text { were used to detect group } \\
\text { differences in baseline to } \\
\text { postintervention changes. } \\
\text { Categorical variables were } \\
\text { analyzed using Chi-square } \\
\text { analysis/Fisher's exact test. } \\
\text { Intention-to-treat analysis was } \\
\text { not performed. } \\
\text { No missing values were } \\
\text { identified, nor were they } \\
\text { addressed. }\end{array}$ \\
\hline Findings & $\begin{array}{l}\text { Was information about } \\
\text { statistical significance } \\
\text { presented? Was } \\
\text { information about effect } \\
\text { size and precision of } \\
\text { estimates (confidence } \\
\text { intervals) presented? }\end{array}$ & $\begin{array}{l}\text { Statistical significance was } \\
\text { presented. } \\
\text { The findings were well } \\
\text { summarized including tables } \\
\text { and figures. } \\
\text { The findings suggested the } \\
\text { need for further studies to }\end{array}$ \\
\hline
\end{tabular}




\begin{tabular}{|c|c|c|}
\hline & $\begin{array}{l}\text { Were the findings } \\
\text { adequately summarized, } \\
\text { with good use of tables and } \\
\text { figures? } \\
\text { - Were findings reported in a } \\
\text { manner that facilitates a } \\
\text { meta-analysis, and with } \\
\text { sufficient information } \\
\text { needed for EBP? }\end{array}$ & $\begin{array}{l}\text { include blood levels of various } \\
\text { outcomes, as well as urine } \\
\text { levels. }\end{array}$ \\
\hline $\begin{array}{l}\text { Discussion } \\
\text { Interpretation of the } \\
\text { findings }\end{array}$ & $\begin{array}{l}\text { Were all major findings } \\
\text { interpreted and discussed } \\
\text { within the context of prior } \\
\text { research and/or the study’s } \\
\text { conceptual framework? } \\
\text { - Were casual inferences, if } \\
\text { any, justified? } \\
\text { - Was the issue of clinical } \\
\text { significance discussed? } \\
\text { - Were interpretations well- } \\
\text { founded and consistent } \\
\text { with the study’s } \\
\text { limitations? } \\
\text { Did the report address the } \\
\text { issue of the generalizability } \\
\text { of the findings? }\end{array}$ & $\begin{array}{l}\text { The findings were discussed in } \\
\text { the context of the research } \\
\text { question. } \\
\text { Casual inferences were made } \\
\text { and justified given the results } \\
\text { of the study. } \\
\text { Clinical significance was } \\
\text { discussed and interpretations } \\
\text { appropriate. } \\
\text { The authors did not attempt to } \\
\text { generalize and overtly stated } \\
\text { findings were not generalizable } \\
\text { to areas outside of day surgery. }\end{array}$ \\
\hline $\begin{array}{l}\text { Implications/ } \\
\text { recommendations }\end{array}$ & 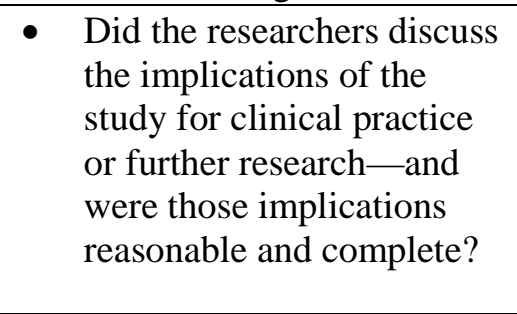 & $\begin{array}{l}\text { The authors reasonably } \\
\text { identified the need for further } \\
\text { study into blood levels of } \\
\text { neurotransmitters, cortisol, skin } \\
\text { temperatures, as well as urine } \\
\text { levels. Implications of the } \\
\text { study were reasonable. }\end{array}$ \\
\hline $\begin{array}{l}\text { General Issues } \\
\text { Presentation }\end{array}$ & $\begin{array}{l}\text { - Was the report well- } \\
\text { written, organized, and } \\
\text { sufficiently detailed for } \\
\text { critical analysis? } \\
\text { - In intervention studies, was } \\
\text { a CONSORT flowchart } \\
\text { provided to show the flow } \\
\text { of participants in the study? } \\
\text { - Was the report written in a } \\
\text { manner that makes the } \\
\text { findings accessible to } \\
\text { practicing nurses? }\end{array}$ & $\begin{array}{l}\text { The report was easy to follow, } \\
\text { well organized and somewhat } \\
\text { detailed. } \\
\text { The report was written in a } \\
\text { manner that is accessible for } \\
\text { practicing nurses. }\end{array}$ \\
\hline Researcher credibility & $\begin{array}{l}\text { Do the researchers' clinical, } \\
\text { substantive, or } \\
\text { methodologic qualifications } \\
\text { and experience enhance } \\
\text { confidence in the findings } \\
\text { and their interpretation? }\end{array}$ & $\begin{array}{l}\text { There was little information } \\
\text { about the authors' } \\
\text { qualifications and experience, } \\
\text { presented only in a footnote on } \\
\text { first page. }\end{array}$ \\
\hline
\end{tabular}




\begin{tabular}{|l|l|l|}
\hline Summary assessment & $\begin{array}{l}\text { Despite any limitations, do } \\
\text { the study findings appear to } \\
\text { be valid-do you have } \\
\text { confidence in the truth } \\
\text { value of the results? }\end{array}$ & $\begin{array}{l}\text { Study findings appeared to be } \\
\text { valid and to have truth value. } \\
\text { The study identified a problem } \\
\text { and demonstrated a need for }\end{array}$ \\
& $\begin{array}{l}\text { Does the study contribute } \\
\text { any meaningful evidence } \\
\text { that can be used in nursing } \\
\text { practice or that is useful to } \\
\text { the nursing discipline? }\end{array}$ & variables. \\
& & \\
\hline
\end{tabular}




\section{Appendix A-10}

Palmer, J. B. et al. (2015). Effects of music therapy on anesthesia requirements and anxiety in women undergoing ambulatory breast surgery for cancer diagnosis and treatment: a randomized controlled trial. Journal of Clinical Oncology,33(28), 3162-3168. doi:10.1200/jco.2014.59.6049

\begin{tabular}{|c|c|c|}
\hline Aspect of the Report & Critiquing Questions & $\begin{array}{l}\text { Detailed Critiquing } \\
\text { Guidelines }\end{array}$ \\
\hline Title & $\begin{array}{l}\text { Is the title a good one, } \\
\text { succinctly suggesting key } \\
\text { variables and the study } \\
\text { population? }\end{array}$ & $\begin{array}{l}\text { The title clearly identified the } \\
\text { subject, location, and key } \\
\text { variables of the study. }\end{array}$ \\
\hline Abstract & $\begin{array}{l}\text { Did the abstract clearly and } \\
\text { concisely summarize the } \\
\text { main features of the report } \\
\text { (problem, methods, results, } \\
\text { conclusions)? }\end{array}$ & $\begin{array}{l}\text { The abstract thoroughly } \\
\text { outlined all the components of } \\
\text { the study and broke it up into } \\
\text { separate sections for clarity. }\end{array}$ \\
\hline $\begin{array}{l}\text { Introduction } \\
\text { Statement of the } \\
\text { problem }\end{array}$ & $\begin{array}{l}\text { Was the problem stated } \\
\text { unambiguously, and was it } \\
\text { easy to identify? } \\
\text { - Is the problem statement } \\
\text { build a persuasive argument } \\
\text { for the new study? } \\
\text { - Was there a good match } \\
\text { between the research } \\
\text { problem and the methods } \\
\text { used -that is, was a } \\
\text { quantitative approach } \\
\text { appropriate? }\end{array}$ & $\begin{array}{l}\text { The problem was easily } \\
\text { identified, clear, and suggested } \\
\text { a need for study. } \\
\text { The introduction suggested the } \\
\text { benefits of music and its' } \\
\text { anxiolytic effects, as well as } \\
\text { decreased anesthetic } \\
\text { requirements. The authors } \\
\text { build s a persuasive argument } \\
\text { for testing live music as } \\
\text { opposed to prerecorded music. } \\
\text { Relevance to nursing clinical } \\
\text { practice was clearly stated. } \\
\text { A three-group randomized } \\
\text { controlled trial was conducted, } \\
\text { which is an excellent match for } \\
\text { the research problem and } \\
\text { methods used. }\end{array}$ \\
\hline $\begin{array}{l}\text { Hypotheses or } \\
\text { research questions }\end{array}$ & $\begin{array}{l}\text { - Were research questions } \\
\text { and/or hypotheses explicitly } \\
\text { stated? If not, was their } \\
\text { absence justified? } \\
\text { - Were questions and } \\
\text { hypotheses appropriately } \\
\text { worded, with clear } \\
\text { specification of key } \\
\text { variables and the study } \\
\text { population? } \\
\text { Were the } \\
\text { questions/hypotheses } \\
\text { consistent with existing } \\
\text { knowledge? }\end{array}$ & $\begin{array}{l}\text { The objective of the study was } \\
\text { explicitly stated, as well as } \\
\text { primary and secondary } \\
\text { hypotheses. Hypotheses were } \\
\text { clear and included appropriate } \\
\text { key variables and study } \\
\text { population. Key variables } \\
\text { were anxiety levels, anesthetic } \\
\text { requirement, recovery time and } \\
\text { patient satisfaction. The } \\
\text { hypotheses were consistent } \\
\text { with existing knowledge. }\end{array}$ \\
\hline
\end{tabular}




\begin{tabular}{|c|c|c|}
\hline Literature review & $\begin{array}{l}\text { Was the literature review } \\
\text { up-to-date and based } \\
\text { mainly on primary sources? } \\
\text { Did the review provide a } \\
\text { state-of-the-art synthesis of } \\
\text { evidence on the problem? } \\
\text { Did the literature review } \\
\text { provide a strong basis for } \\
\text { the new study? }\end{array}$ & $\begin{array}{l}\text { The literature review discussed } \\
\text { previous studies and built a } \\
\text { strong basis for a new study } \\
\text { using live music as opposed to } \\
\text { prerecorded music. The } \\
\text { literature review was brief, but } \\
\text { provided a good synthesis of } \\
\text { evidence on the problem. }\end{array}$ \\
\hline $\begin{array}{l}\text { Conceptual/theoretical } \\
\text { framework }\end{array}$ & $\begin{array}{l}\text { - Were key concepts } \\
\text { adequately defined } \\
\text { conceptually? } \\
\text { - Was a } \\
\text { conceptual/theoretical } \\
\text { framework articulated- } \\
\text { and, if so, was it } \\
\text { appropriate? If not, is the } \\
\text { absence of a framework } \\
\text { justified? } \\
\text { Were the } \\
\text { questions/hypotheses } \\
\text { consistent with the } \\
\text { framework? }\end{array}$ & $\begin{array}{l}\text { There was no theoretical } \\
\text { framework identified. } \\
\text { Concepts were adequately } \\
\text { defined. }\end{array}$ \\
\hline $\begin{array}{l}\text { Method } \\
\text { Protection of human } \\
\text { rights }\end{array}$ & $\begin{array}{l}\text { Were appropriate } \\
\text { procedures used to safe- } \\
\text { guard the rights of study } \\
\text { participants? } \\
\text { - Was the study externally } \\
\text { reviewed by an IRB/ethics } \\
\text { review board? } \\
\text { Was the study designed to } \\
\text { minimize risks and } \\
\text { maximize benefits to } \\
\text { participants? }\end{array}$ & $\begin{array}{l}\text { Appropriate procedures were } \\
\text { used to safeguard rights of } \\
\text { patients. } \\
\text { Study was approved by The } \\
\text { University Hospitals Case } \\
\text { Medical Center IRB. Written } \\
\text { informed consent was obtained } \\
\text { from all participants. } \\
\text { The study was designed to } \\
\text { minimize risks and maximize } \\
\text { benefits to participants. }\end{array}$ \\
\hline Research design & $\begin{array}{l}\text { - Was the most rigorous } \\
\text { design used, given the study } \\
\text { purpose? } \\
\text { - Were appropriate } \\
\text { comparisons made to } \\
\text { enhance interpretability of } \\
\text { the findings? } \\
\text { - Was the number of data } \\
\text { collection points } \\
\text { appropriate? } \\
\text { Did the design minimize } \\
\text { biases and threats to the } \\
\text { internal, construct, and } \\
\text { external validity of the } \\
\text { study (e.g., was blinding }\end{array}$ & $\begin{array}{l}\text { The design used was consistent } \\
\text { with study goals and purpose. } \\
\text { An online randomization } \\
\text { module was used, which } \\
\text { ensured adequate concealment. } \\
\text { The design used appropriate } \\
\text { comparisons of the three } \\
\text { groups to enhance } \\
\text { interpretability. The three } \\
\text { groups included a live music } \\
\text { group, a prerecorded music } \\
\text { group and a usual care group } \\
\text { without music. } \\
\text { The study was designed to } \\
\text { minimize bias and threats to } \\
\text { internal validity. A permuted }\end{array}$ \\
\hline
\end{tabular}




\begin{tabular}{|c|c|c|}
\hline & $\begin{array}{l}\text { used, was attrition } \\
\text { minimized)? }\end{array}$ & $\begin{array}{l}\text { block randomization scheme } \\
\text { was used to prevent personnel } \\
\text { performing study to guess next } \\
\text { assignment. Nurses were not } \\
\text { able to be blinded, however. } \\
\text { The number of data points } \\
\text { were adequate, } \mathrm{N}=201 \text {. }\end{array}$ \\
\hline $\begin{array}{l}\text { Population and } \\
\text { sample }\end{array}$ & $\begin{array}{l}\text { Was the population } \\
\text { identified? Was the sample } \\
\text { described in sufficient } \\
\text { detail? } \\
\text { - Was the best possible } \\
\text { sampling design used to } \\
\text { enhance the sample's } \\
\text { representativeness? Were } \\
\text { sampling biases minimized? } \\
\text { Was the sample size based } \\
\text { on a power analysis? }\end{array}$ & $\begin{array}{l}\text { The population was briefly and } \\
\text { adequately identified in the } \\
\text { introduction. The sample was } \\
\text { recruited from two hospitals in } \\
\text { Ohio. Purposive sampling was } \\
\text { used. A flowchart (CONSORT } \\
\text { diagram) was made to identify } \\
\text { patient early termination and } \\
\text { random selection of } \\
\text { participants in each group. The } \\
\text { reason for exclusion was } \\
\text { provided as well in the } \\
\text { flowchart, i.e. cancelled } \\
\text { surgery, missing post-test due } \\
\text { to time restraints and recovery } \\
\text { data not collected. } \\
\text { The design was adequate for r } \\
\text { this type of study. } \\
\text { A power analysis was used. } \\
\text { Sample size (N=201) was } \\
\text { adequate based on the power } \\
\text { analysis. }\end{array}$ \\
\hline $\begin{array}{l}\text { Data collection and } \\
\text { measurement }\end{array}$ & $\begin{array}{l}\text { Were the operational and } \\
\text { conceptual definitions } \\
\text { congruent? } \\
\text { Were key variables } \\
\text { measured using an } \\
\text { appropriate method (e.g., } \\
\text { interviews, observations, } \\
\text { and so on)? } \\
\text { - Were specific instruments } \\
\text { adequately described and } \\
\text { were they good choices, } \\
\text { given the study population } \\
\text { and the variables being } \\
\text { studied? } \\
\text { Did the report provide } \\
\text { evidence that the data } \\
\text { collection methods yielded } \\
\text { data that were reliable, } \\
\text { valid and responsive? }\end{array}$ & $\begin{array}{l}\text { The authors performed the } \\
\text { study as they conceptualized it. } \\
\text { Key variables were measured } \\
\text { appropriately using GA-VAS } \\
\text { cores, patient satisfaction, } \\
\text { amount of Propofol required to } \\
\text { reach BIS level of 70, vital } \\
\text { signs, and time to discharge } \\
\text { readiness; all were appropriate } \\
\text { for this study. } \\
\text { The report provided no } \\
\text { evidence that the GA-VAS is } \\
\text { valid or reliable. }\end{array}$ \\
\hline
\end{tabular}




\begin{tabular}{|c|c|c|}
\hline Procedures & $\begin{array}{l}\text { - If there was an intervention, } \\
\text { was it adequately described, } \\
\text { and was it rigorously } \\
\text { developed and } \\
\text { implemented? Did most } \\
\text { participants allocated to the } \\
\text { intervention group actually } \\
\text { receive it? Was there } \\
\text { evidence of intervention } \\
\text { fidelity? } \\
\text { Were data collected in a } \\
\text { manner that minimized } \\
\text { bias? Were the staff who } \\
\text { collected data appropriately } \\
\text { trained? }\end{array}$ & $\begin{array}{l}\text { Intervention was adequately } \\
\text { described and rigorously } \\
\text { developed and implemented. } \\
68 \text { out of } 69 \text { randomly } \\
\text { assigned to the live and } \\
\text { recorded music were included } \\
\text { in analysis. } 68 \text { out of } 70 \\
\text { randomly assigned to recorded } \\
\text { music only were included in } \\
\text { analysis. Lastly, } 65 \text { out of } 68 \\
\text { randomly assigned to usual } \\
\text { care and noise blocking } \\
\text { earmuffs were included in } \\
\text { analysis. } \\
\text { All interventions were } \\
\text { administered as intended. } \\
\text { Data were collected in manner } \\
\text { consistent with minimal bias, } \\
\text { with randomized and blinding } \\
\text { techniques. It was not noted if } \\
\text { staff were trained. }\end{array}$ \\
\hline Data Analysis & $\begin{array}{l}\text { - Were analyses undertaken } \\
\text { to address each research } \\
\text { question or test each } \\
\text { hypothesis? } \\
\text { - Were appropriate statistical } \\
\text { methods used, given the } \\
\text { level of measurement of the } \\
\text { variables, number of groups } \\
\text { being compared, and } \\
\text { assumptions of the texts? } \\
\text { - Was a powerful analytic } \\
\text { method used? (e.g., did the } \\
\text { analysis help to control for } \\
\text { confounding variables)? } \\
\text { Were type I and Type II } \\
\text { errors avoided or } \\
\text { minimized? } \\
\text { In intervention studies, was } \\
\text { an intention-to-treat } \\
\text { analysis performed? } \\
\text { Were problems of missing } \\
\text { values evaluated and } \\
\text { adequately addressed? }\end{array}$ & $\begin{array}{l}\text { The data were appropriately } \\
\text { analyzed to address the } \\
\text { research question. } \\
\text { The statistical method was } \\
\text { appropriate. } \\
\text { Powerful analytic method was } \\
\text { not used. } \\
\text { Intention-to-treat analysis was } \\
\text { performed to analyze data. } \\
\text { Pairwise Wilcoxon rank sum } \\
\text { tests were used to compare } \\
\text { outcomes between study arms. } \\
\text { It is of note that no multiple } \\
\text { testing correction was made to } \\
\text { account for two primary } \\
\text { outcomes and that results } \\
\text { would not change if such a } \\
\text { correction was made. A pretest } \\
\text { and post-test method was used } \\
\text { to analyze GA-VAS scores. } \\
\text { Study data were collected and } \\
\text { managed using Research } \\
\text { Electronic Data Capture } \\
\text { (REDcap) tools. Audit trails } \\
\text { were kept. } \\
\text { No missing values were } \\
\text { identified, nor were they } \\
\text { addressed. }\end{array}$ \\
\hline
\end{tabular}




\begin{tabular}{|c|c|c|}
\hline Findings & $\begin{array}{l}\text { Was information about } \\
\text { statistical significance } \\
\text { presented? Was } \\
\text { information about effect } \\
\text { size and precision of } \\
\text { estimates (confidence } \\
\text { intervals) presented? } \\
\text { - Were the findings } \\
\text { adequately summarized, } \\
\text { with good use of tables and } \\
\text { figures? } \\
\text { Were findings reported in a } \\
\text { manner that facilitates a } \\
\text { meta-analysis, and with } \\
\text { sufficient information } \\
\text { needed for EBP? }\end{array}$ & $\begin{array}{l}\text { Information regarding } \\
\text { statistical tests was presented, } \\
\text { as well as confidence intervals. } \\
\text { The findings were well } \\
\text { summarized including three } \\
\text { tables and a plot diagram. } \\
\text { The findings suggested the } \\
\text { need for further studies } \\
\text { regarding therapeutic value of } \\
\text { music therapy, specifically in } \\
\text { the perioperative setting. }\end{array}$ \\
\hline $\begin{array}{l}\text { Discussion } \\
\text { Interpretation of the } \\
\text { findings }\end{array}$ & $\begin{array}{l}\text { Were all major findings } \\
\text { interpreted and discussed } \\
\text { within the context of prior } \\
\text { research and/or the study’s } \\
\text { conceptual framework? } \\
\text { - Were casual inferences, if } \\
\text { any, justified? } \\
\text { - Was the issue of clinical } \\
\text { significance discussed? } \\
\text { Were interpretations well- } \\
\text { founded and consistent with } \\
\text { the study's limitations? } \\
\text { Did the report address the } \\
\text { issue of the generalizability } \\
\text { of the findings? }\end{array}$ & $\begin{array}{l}\text { The findings were discussed in } \\
\text { the context of the research } \\
\text { question. } \\
\text { Casual inferences were made } \\
\text { and justified given the results } \\
\text { of the study. } \\
\text { Clinical significance was } \\
\text { discussed and interpretations } \\
\text { appropriate. } \\
\text { The study did not attempt to } \\
\text { generalize and overtly stated it } \\
\text { is not generalizable to areas } \\
\text { outside of women undergoing } \\
\text { breast surgery. The study } \\
\text { stated that findings may } \\
\text { provide a basis for future } \\
\text { studies regarding evaluating } \\
\text { music therapy in different } \\
\text { surgical procedures. }\end{array}$ \\
\hline $\begin{array}{l}\text { Implications/ } \\
\text { recommendations }\end{array}$ & $\begin{array}{l}\text { Did the researchers discuss } \\
\text { the implications of the } \\
\text { study for clinical practice or } \\
\text { further research-and were } \\
\text { those implications } \\
\text { reasonable and complete? }\end{array}$ & $\begin{array}{l}\text { The authors reasonably } \\
\text { identified the need for further } \\
\text { quantitative study as stated } \\
\text { above. }\end{array}$ \\
\hline $\begin{array}{l}\text { General Issues } \\
\text { Presentation }\end{array}$ & $\begin{array}{l}\text { - Was the report well-written, } \\
\text { organized, and sufficiently } \\
\text { detailed for critical } \\
\text { analysis? } \\
\text { - In intervention studies, was } \\
\text { a CONSORT flowchart } \\
\text { provided to show the flow } \\
\text { of participants in the study? }\end{array}$ & $\begin{array}{l}\text { The report was easy to follow, } \\
\text { well organized and very } \\
\text { detailed. } \\
\text { It was written in a manner that } \\
\text { is accessible for practicing } \\
\text { nurses. }\end{array}$ \\
\hline
\end{tabular}




\begin{tabular}{|c|c|c|}
\hline & $\begin{array}{l}\text { - Was the report written in a } \\
\text { manner that makes the } \\
\text { findings accessible to } \\
\text { practicing nurses? }\end{array}$ & \\
\hline Researcher credibility & $\begin{array}{l}\text { Do the researchers' clinical, } \\
\text { substantive, or } \\
\text { methodologic qualifications } \\
\text { and experience enhance } \\
\text { confidence in the findings } \\
\text { and their interpretation? }\end{array}$ & $\begin{array}{l}\text { Information was provided on } \\
\text { the first page about the } \\
\text { authors' hospital affiliations. } \\
\text { The last page of the article } \\
\text { included authors' contributions } \\
\text { and disclosures. The authors' } \\
\text { qualifications and experience } \\
\text { were not explicitly included. }\end{array}$ \\
\hline Summary assessment & 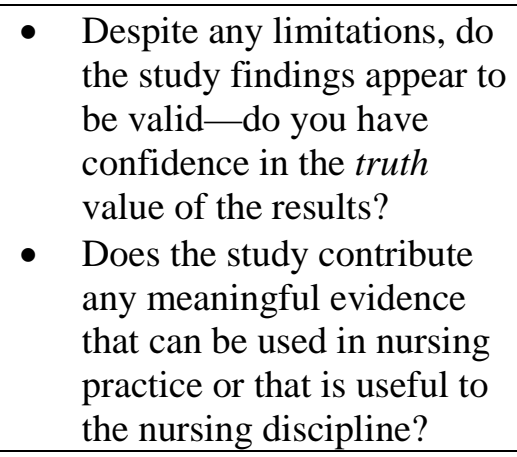 & $\begin{array}{l}\text { The study appeared to be valid } \\
\text { and results appeared to have } \\
\text { truth value. } \\
\text { The study identified a problem } \\
\text { and showed a need for further } \\
\text { research regarding the } \\
\text { therapeutic value of music } \\
\text { therapy, particularly in the } \\
\text { perioperative setting. }\end{array}$ \\
\hline
\end{tabular}




\section{Appendix B-1}

Arslan, S., Ozer, N., \& Ozyurt, F. (2008). Effect of music on preoperative anxiety in men undergoing urogenital surgery. Australian Journal of Advanced Nursing, 26(2), 46-54

\begin{tabular}{|c|c|c|c|}
\hline Purpose & Findings & $\begin{array}{l}\text { Limitations to the } \\
\text { study }\end{array}$ & $\begin{array}{l}\text { Suggestions or } \\
\text { interventions to } \\
\text { improve }\end{array}$ \\
\hline $\begin{array}{l}\text { To investigate the } \\
\text { effect of music } \\
\text { therapy on } \\
\text { preoperative anxiety } \\
\text { levels in Turkish men } \\
\text { undergoing } \\
\text { urogenital surgery. }\end{array}$ & $\begin{array}{l}\text { Anxiety mean scores } \\
\text { between groups after } \\
\text { music therapy were } \\
\text { statistically } \\
\text { significant (p<0.001). } \\
\text { Measured using State } \\
\text { Trait Anxiety } \\
\text { Inventory (STAI) } \\
\text { scores. } \\
\text { Results included: } \\
\text { Before therapy mean } \\
\text { score of } 39.59 \text { and } \\
\text { after therapy } 33.68 \\
\text { for experimental } \\
\text { group. Before therapy } \\
\text { mean score of } 42.25 \\
\text { and after therapy } \\
44.43 \text { for the control } \\
\text { group. }\end{array}$ & $\begin{array}{l}\text { Small sample size } \\
(\mathrm{N}=64) \text {. } \\
\text { Confined to one } \\
\text { geographical area in } \\
\text { Turkey. }\end{array}$ & $\begin{array}{l}\text { The authors } \\
\text { suggested to improve } \\
\text { the study, a larger } \\
\text { sample size would be } \\
\text { needed. } \\
\text { The authors } \\
\text { investigating } \\
\text { effectiveness of } \\
\text { listening to preferred } \\
\text { music for other } \\
\text { patient populations. }\end{array}$ \\
\hline
\end{tabular}




\section{Appendix B-2}

Dong, Y. \& Li, Y. (2012). Preoperative music intervention for patients undergoing cesarean delivery. International Journal of Gynecology \& Obstetrics,119(1), 81-83. doi:10.1016/j.ijgo.2012.05.017

\begin{tabular}{|c|c|c|c|}
\hline Purpose & Findings & $\begin{array}{l}\text { Limitations to the } \\
\text { study }\end{array}$ & $\begin{array}{l}\text { Suggestions or } \\
\text { interventions to } \\
\text { improve }\end{array}$ \\
\hline $\begin{array}{l}\text { To evaluate the } \\
\text { effects of music } \\
\text { played preoperatively } \\
\text { in women undergoing } \\
\text { elective cesarean } \\
\text { delivery. }\end{array}$ & $\begin{array}{l}\text { No significant } \\
\text { differences in } \\
\text { demographics between } \\
\text { the two groups were } \\
\text { detected. The two } \\
\text { groups included a study } \\
\text { group exposed to music } \\
\text { for } 30 \text { minutes (n=30) } \\
\text { and a control group who } \\
\text { received standard care } \\
\text { (n=30). } \\
\text { Changes within groups: } \\
\text { mean LF and LF/HF } \\
\text { values were significantly } \\
\text { lower and mean HF } \\
\text { significantly higher after } \\
\text { music therapy (p<0.05 } \\
\text { for all). Overall } \\
\text { differences in values for } \\
\text { LF showed intervention } \\
\text { group differences of } \\
119.50 \pm 201.58 \text { and in } \\
\text { the control group -15.86 } \\
\pm 71.29 \text {. The HF showed } \\
\text { differences in the } \\
\text { intervention group of - } \\
113.00 \pm 130.62 \text { and } \\
\text { control group } 14.45 \pm \\
51.40 \text {. LF/HF showed } \\
\text { intervention group } \\
\text { differences of } 0.69 \pm \\
0.51 \text { within the } \\
\text { intervention group and } \\
\text { control group } 0.00 \pm \\
0.50 \text {. The control group } \\
\text { changes in mean values } \\
\text { for LF, HF, and LF/HF } \\
\text { ratio were not } \\
\text { significant. } \\
\text { The mean SAS score } \\
\text { was significantly less } \\
\text { (p<0.05) and unchanged }\end{array}$ & $\begin{array}{l}\text { Anesthetic drugs } \\
\text { influence HRV } \\
\text { values. }\end{array}$ & $\begin{array}{l}\text { The authors suggested } \\
\text { including the } \\
\text { evaluation of } \\
\text { intraoperative and } \\
\text { postoperative } \\
\text { differences. } \\
\text { Authors suggested } \\
\text { future studies to } \\
\text { combine music } \\
\text { intervention with other } \\
\text { nonpharmacologic } \\
\text { methods considered } \\
\text { apt to decrease } \\
\text { sympathetic and } \\
\text { increase } \\
\text { parasympathetic } \\
\text { nervous system } \\
\text { activity. }\end{array}$ \\
\hline
\end{tabular}




\begin{tabular}{|l|l|l|l|}
\hline & in control group. & & \\
Difference in values for & & \\
the intervention group in & & & \\
terms of VAS scores & & \\
were $7.20 \pm 2.09$ and & & & \\
$0.03 \pm 3.50$ for the & & \\
control group. & & \\
Changes between & & & \\
groups: mean SAS score & & & \\
& and HRV values were & & \\
& significantly greater than & & \\
& control (p<0.01). & & \\
\hline
\end{tabular}




\section{Appendix B-3}

Ertuğ, N., Ulusoylu, Ö, Bal, A., \& Özgür, H. (2017). Comparison of the effectiveness of two different interventions to reduce preoperative anxiety: A randomized controlled study. Nursing \& Health Sciences,19(2), 250-256. doi:10.1111/nhs.12339

\begin{tabular}{|c|c|c|c|}
\hline Purpose & Findings & $\begin{array}{l}\text { Limitations to } \\
\text { the study }\end{array}$ & $\begin{array}{l}\text { Suggestions or } \\
\text { interventions to } \\
\text { improve }\end{array}$ \\
\hline $\begin{array}{l}\text { To determine and } \\
\text { compare the } \\
\text { effectiveness of } \\
\text { nature sounds and } \\
\text { relaxation } \\
\text { exercises for } \\
\text { reducing } \\
\text { preoperative } \\
\text { anxiety. }\end{array}$ & $\begin{array}{l}\text { Measured using State Anxiety } \\
\text { Inventory (SAI) and Visual } \\
\text { Analog Scale (VAS). } \\
\text { Results included: } \\
\text { A p value of }<0.005 \text { was } \\
\text { accepted as statistically } \\
\text { significant. } \\
\text { There was no statistically } \\
\text { significant difference in the } \\
\text { VAS (p=0.441) or SAI } \\
\text { (p=0.063) scores between the } \\
\text { three groups. VAS scores after } \\
\text { the } 30-\text {-minute intervention } \\
\text { were lower in nature sounds } \\
\text { groups and relaxation } \\
\text { exercises group than the } \\
\text { control group (3.10 } \pm 1.68 \text {, } \\
3.28 \pm 1.80,5.44 \pm 2.66 \text {; } \\
p=0.011 \text { ). Post hoc analysis } \\
\text { showed that the control group } \\
\text { have higher VAS scores } \\
\text { (p<0.016). SAI scores } 30 \text { - } \\
\text { minutes after intervention } \\
\text { were lower in both the nature } \\
\text { sounds and relaxation groups } \\
\text { ( }<0.01 \text { ), but no statistically } \\
\text { significant difference noted } \\
\text { between those two groups } \\
\text { (p=0.0870). According to a } \\
\text { Pearson correlation analysis, a } \\
\text { strong correlation was found } \\
\text { between VAS and SAI scores. }\end{array}$ & $\begin{array}{l}\text { Not blinded. } \\
\text { Intervention lasted } \\
\text { for only one } \\
\text { session. } \\
\text { Interaction } \\
\text { between } \\
\text { participant and } \\
\text { relative for } 30 \\
\text { minutes in } \\
\text { between } \\
\text { measurements. }\end{array}$ & $\begin{array}{l}\text { The authors } \\
\text { suggested conducting } \\
\text { multiple sessions to } \\
\text { compare results. The } \\
\text { VAS and SAI are } \\
\text { self-reporting scales } \\
\text { and therefore } \\
\text { subjective. In } \\
\text { addition, they } \\
\text { suggested using a } \\
\text { more objective tool to } \\
\text { measure anxiety } \\
\text { levels. }\end{array}$ \\
\hline
\end{tabular}




\section{Appendix B-4}

Ghetti, C. M. (2013). Effect of music therapy with emotional-approach coping on Preprocedural Anxiety in Cardiac Catheterization: A Randomized Controlled Trial. Journal of Music Therapy,50(2), 93-122. doi:10.1093/jmt/50.2.93

\begin{tabular}{|c|c|c|c|}
\hline Purpose & Findings & $\begin{array}{l}\text { Limitations } \\
\text { to the study }\end{array}$ & $\begin{array}{l}\text { Suggestions or } \\
\text { interventions to } \\
\text { improve }\end{array}$ \\
\hline $\begin{array}{l}\text { To evaluate the use } \\
\text { of music therapy, } \\
\text { with a specific } \\
\text { emphasis on } \\
\text { emotional-approach } \\
\text { coping, immediately } \\
\text { prior to cardiac } \\
\text { catherization on } \\
\text { preprocedural } \\
\text { anxiety and } \\
\text { periprocedural } \\
\text { outcomes. }\end{array}$ & $\begin{array}{l}\text { Measured using physiological } \\
\text { variables, i.e. vital signs, } \\
\text { psychological variables } \\
\text { (PANAS) and procedural } \\
\text { variables (use of medications and } \\
\text { length of procedure. } \\
\text { Results included: } \\
\text { Participants receiving music } \\
\text { therapy showed significant } \\
\text { increase in positive affect from } \\
\text { pre- to posttest, but EAC and } \\
\text { control groups did not. Positive } \\
\text { affect results in the MT/EAC } \\
\text { group showed pre (28.54) and } \\
\text { post (33.46); the EAC group } \\
\text { showed pre (31.48) and post } \\
\text { (32.29); and the control group } \\
\text { showed pre (30.60) and post } \\
\text { (30.50). In terms of negative } \\
\text { affects, the MT/EAC group } \\
\text { showed pre (15.62) and post } \\
\text { (12.69); the EAC group showed } \\
\text { pre (19.93) and post (17.86); the } \\
\text { control group showed pre (14.30) } \\
\text { and post (14.30). } \\
\text { No statistical significance } \\
\text { between groups of any of the } \\
\text { psychological or physiological } \\
\text { variables at the pretest. } \\
\text { Psychological variables: t-tests } \\
\text { showed that music } \\
\text { therapy(MT)/emotional-approach } \\
\text { coping (EAC) group showed } \\
\text { statistical significance with } \\
\text { positive affect from pre- to } \\
\text { posttest scores (-8.21 to -1.64; } \\
\text { p=0.007). The EAC group did } \\
\text { not change from pre- to posttest } \\
\text { regarding positive affect, } \\
\text { however the MT group only } \\
\text { showed an increase in positive }\end{array}$ & $\begin{array}{l}\text { Small sample } \\
\text { size (N=37). } \\
\text { High rate of } \\
\text { rejection of } \\
\text { participants. }\end{array}$ & $\begin{array}{l}\text { An intervention to } \\
\text { refine the study per } \\
\text { the author may } \\
\text { include a larger } \\
\text { sample size. } \\
\text { The author } \\
\text { suggested longer } \\
\text { treatment times. In } \\
\text { addition, they } \\
\text { suggested the } \\
\text { inclusion of } \\
\text { inpatient and } \\
\text { outpatient } \\
\text { populations to } \\
\text { enhance } \\
\text { generalizability. }\end{array}$ \\
\hline
\end{tabular}




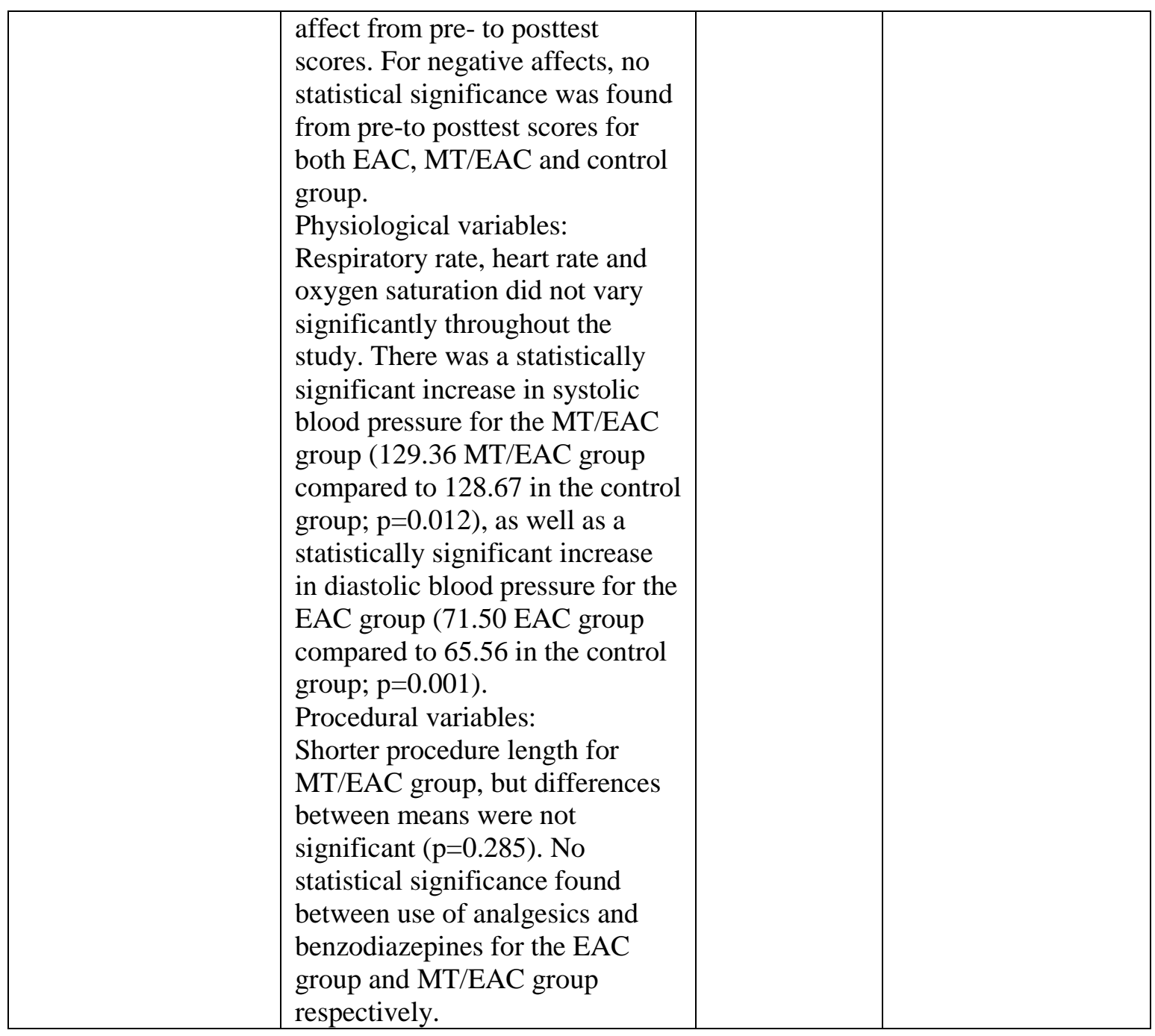




\section{Appendix B-5}

Kovac, M. (2014). Music interventions for the treatment of preoperative anxiety. Journal of Consumer Health on the Internet,18(2), 193-201. doi:10.1080/15398285.2014.902282

\begin{tabular}{|c|c|c|c|}
\hline Purpose & Findings & $\begin{array}{l}\text { Limitations to the } \\
\text { review }\end{array}$ & Future research \\
\hline $\begin{array}{l}\text { Literature review to } \\
\text { investigate different } \\
\text { types of music } \\
\text { interventions for the } \\
\text { treatment of } \\
\text { preoperative anxiety. }\end{array}$ & $\begin{array}{l}\text { Music interventions } \\
\text { both passive and } \\
\text { active, influence } \\
\text { patients } \\
\text { physiologically (vital } \\
\text { signs) and } \\
\text { emotionally (i.e. } \\
\text { anxiety). }\end{array}$ & $\begin{array}{l}\text { Logistical problems: } \\
\text { No standardization } \\
\text { across studies. } \\
\text { Preferred music not } \\
\text { offered by } \\
\text { researchers. } \\
\text { Difficulty with } \\
\text { headphones. }\end{array}$ & $\begin{array}{l}\text { According to the } \\
\text { author there is no } \\
\text { consensus on } \\
\text { whether provider- } \\
\text { selected music or } \\
\text { patient-selected } \\
\text { music is more } \\
\text { beneficial. }\end{array}$ \\
\hline
\end{tabular}




\section{Appendix B-6}

Kushnir, J. et al. (2012). Coping with preoperative anxiety in cesarean section: physiological, cognitive, and emotional effects of listening to favorite music. Retrieved from http://onlinelibrary.wiley.com/doi/10.1111/j.1523-536X.2012.00532.x/abstract

\begin{tabular}{|c|c|c|c|}
\hline Purpose & Findings & $\begin{array}{l}\text { Limitations to } \\
\text { the study }\end{array}$ & $\begin{array}{l}\text { Suggestions or } \\
\text { interventions to } \\
\text { improve }\end{array}$ \\
\hline $\begin{array}{l}\text { To assess the } \\
\text { effects of listening } \\
\text { to selected music } \\
\text { while waiting for a } \\
\text { cesarean section } \\
\text { on emotional } \\
\text { reactions, } \\
\text { cognitive appraisal } \\
\text { of the threat of } \\
\text { surgery and stress- } \\
\text { related } \\
\text { physiological } \\
\text { reactions. }\end{array}$ & 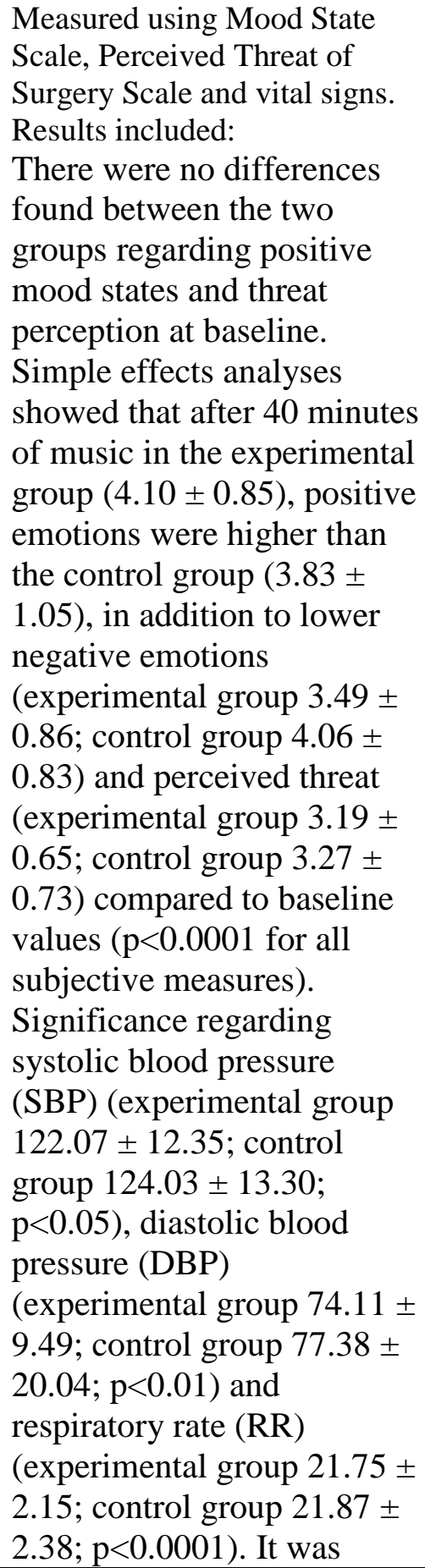 & $\begin{array}{l}\text { Small sample } \\
\text { size }(\mathrm{N}=60) \text {. } \\
\text { No } \\
\text { randomization } \\
\text { to researchers } \\
\text { only } \\
\text { participants. }\end{array}$ & $\begin{array}{l}\text { Authors suggested } \\
\text { to investigate } \\
\text { effectiveness of } \\
\text { selecting music has } \\
\text { an effect on anxiety } \\
\text { and whether } \\
\text { different types of } \\
\text { music have different } \\
\text { influences on stress. } \\
\text { This author would } \\
\text { suggest future } \\
\text { studies use a larger } \\
\text { sample size and } \\
\text { increase } \\
\text { generalizability of } \\
\text { results. }\end{array}$ \\
\hline
\end{tabular}




\begin{tabular}{|c|c|c|}
\hline & & $\begin{array}{l}\text { found that SBP was lower in } \\
\text { the experimental group } \\
\text { compared to baseline and } \\
\text { DBP and RR remain } \\
\text { unchanged compared to } \\
\text { baseline in the experimental } \\
\text { group. However, in the } \\
\text { control group, DBP and RR } \\
\text { were higher and SBP } \\
\text { remained unchanged after } 40 \\
\text { minutes compared to } \\
\text { baseline. }\end{array}$ \\
\hline
\end{tabular}




\section{Appendix B-7}

Labrague, L. J. \& Mcenroe-Petitte, D. M. (2014). Influence of music on preoperative anxiety and physiologic parameters in women undergoing gynecologic surgery. Clinical Nursing Research,25(2), 157-173. doi:10.1177/1054773814544168

\begin{tabular}{|c|c|c|c|}
\hline Purpose & Findings & $\begin{array}{l}\text { Limitations to } \\
\text { the study }\end{array}$ & $\begin{array}{l}\text { Suggestions or } \\
\text { interventions to } \\
\text { improve }\end{array}$ \\
\hline $\begin{array}{l}\text { To determine the } \\
\text { influence of } \\
\text { music on anxiety } \\
\text { levels and the } \\
\text { physiologic } \\
\text { parameters in } \\
\text { women } \\
\text { undergoing } \\
\text { gynecologic } \\
\text { surgery. }\end{array}$ & 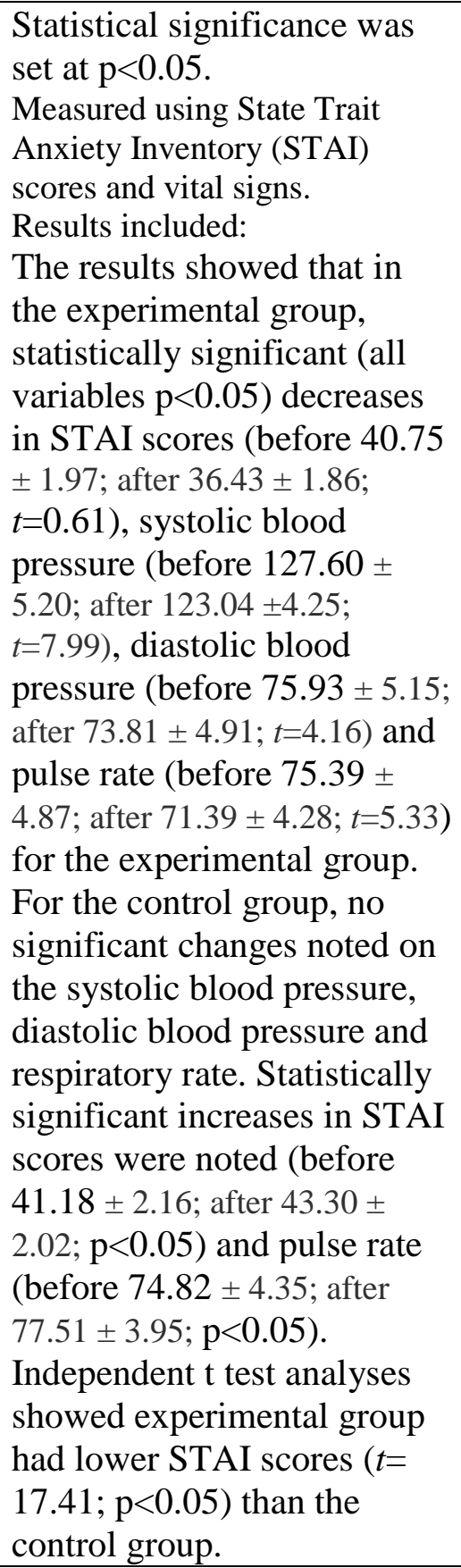 & $\begin{array}{l}\text { Nonrandomization } \\
\text { of participants. } \\
\text { Participants from } \\
\text { one single hospital } \\
\text { facility. }\end{array}$ & $\begin{array}{l}\text { Authors suggested } \\
\text { to conduct a study } \\
\text { comparing different } \\
\text { types of music with } \\
\text { varied listening } \\
\text { duration time to } \\
\text { determine extent of } \\
\text { which music would } \\
\text { exert maximum } \\
\text { benefit in } \\
\text { decreasing anxiety. } \\
\text { In addition, } \\
\text { investigating the } \\
\text { difference between } \\
\text { self-selected music } \\
\text { and researcher- } \\
\text { selected music in } \\
\text { decreasing anxiety } \\
\text { among various } \\
\text { patient population in } \\
\text { surgery. }\end{array}$ \\
\hline
\end{tabular}




\section{Appendix B-8}

Lee, K. et al. (2011). Effectiveness of different music-playing devices for reducing preoperative anxiety: A clinical control study. International Journal of Nursing Studies,48(10), 11801187. doi:10.1016/j.ijnurstu.2011.04.001

\begin{tabular}{|c|c|c|c|}
\hline Purpose & Findings & $\begin{array}{l}\text { Limitations to the } \\
\text { study }\end{array}$ & $\begin{array}{l}\text { Suggestions or } \\
\text { interventions to } \\
\text { improve }\end{array}$ \\
\hline $\begin{array}{l}\text { To investigate the } \\
\text { anxiety relieving } \\
\text { effect of } \\
\text { broadcast versus } \\
\text { headphone music } \\
\text { playing for } \\
\text { patients before } \\
\text { surgery. }\end{array}$ & $\begin{array}{l}\text { Statistical significance } \\
\text { was defined as }<<0.05 \text {. } \\
\text { Measured using Visual } \\
\text { Analog Scale (VAS) and } \\
\text { Heart Rate Variability } \\
\text { (HRV). } \\
\text { Results included: } \\
\text { No statistical significance } \\
\text { between VAS anxiety } \\
\text { levels between broadcast } \\
\text { and headphone group } \\
\text { (p=0.1). The mean } \\
\text { anxiety level for the } \\
\text { control group was } \\
\text { significantly higher than } \\
\text { the headphone and the } \\
\text { broadcast group (5.1 } \pm \\
2.7 ; 4.4 \pm 1.6 \text {; }<0.05 \text { ). } \\
\text { The average heart rates of } \\
\text { the broadcast, headphone } \\
\text { and control group were } \\
\text { not statistically } \\
\text { significant (p<0.17). } \\
\text { Significant difference in } \\
\text { high frequency HR } \\
\text { variability among the } \\
\text { three groups (broadcast } \\
42.5 \text {, headphone } 42.9 \text { and } \\
\text { control } 35.4 ; p<0.01 \text { ), but } \\
\text { no significance between } \\
\text { broadcast and headphone } \\
\text { groups. Significance in } \\
\text { the low frequency HR } \\
\text { variability among the } \\
\text { three groups (broadcast } \\
54.8 \text {, headphone } 57.1 \text { and } \\
\text { control } 64.6 \text {; }<0.01 \text { ). } \\
\text { VAS scores were } \\
\text { significantly correlated to } \\
\text { the frequency-domain } \\
\text { parameters of HR }\end{array}$ & $\begin{array}{l}\text { No pretest-posttest } \\
\text { comparison. } \\
\text { Participants unable } \\
\text { to choose their } \\
\text { favorite music. }\end{array}$ & $\begin{array}{l}\text { The authors } \\
\text { suggested future } \\
\text { studies determine if } \\
\text { reducing anxiety has } \\
\text { lasting effect on } \\
\text { outcomes during } \\
\text { intraoperative and } \\
\text { postoperative periods. } \\
\text { In addition, improve } \\
\text { research design and } \\
\text { add pretest to } \\
\text { determine change. }\end{array}$ \\
\hline
\end{tabular}




\begin{tabular}{|l|l|l|l|}
\hline & $\begin{array}{l}\text { variability (p<0.05), but } \\
\text { not with time-domain } \\
\text { ones. }\end{array}$ & & \\
\hline
\end{tabular}

\section{Appendix B-9}

$\mathrm{Ni}$, C. et al. (2011). Minimising preoperative anxiety with music for day surgery patients- a randomised clinical trial. Journal of Clinical Nursing, 21(5-6), 620-625. Doi:10.1111/j.1365-2702.2010.03466.x

\begin{tabular}{|c|c|c|c|}
\hline Purpose & Findings & $\begin{array}{l}\text { Limitations to } \\
\text { the study }\end{array}$ & $\begin{array}{l}\text { Suggestions or } \\
\text { interventions to } \\
\text { improve }\end{array}$ \\
\hline $\begin{array}{l}\text { To evaluate the } \\
\text { effects of musical } \\
\text { intervention on } \\
\text { preoperative } \\
\text { anxiety and vital } \\
\text { signs in patients } \\
\text { undergoing day } \\
\text { surgery. }\end{array}$ & $\begin{array}{l}\text { Statistical significance defined } \\
\text { as } \mathrm{p}<0.05 \text {. } \\
\text { Measured using State Trait } \\
\text { Anxiety Inventory (STAI) } \\
\text { scores and vital signs. } \\
\text { Results included: } \\
\text { No statistical significance of } \\
\text { STAI scores and vital signs } \\
\text { between the two groups } \\
\text { (p }>0.05 \text { ). Significant decreases } \\
\text { in STAI scores from baseline } \\
\text { were seen in both groups } \\
\text { (p<0.001). STAI scores } \\
\text { decreased my means of } 5.83 \\
\text { and } 1.72 \text { in the music and } \\
\text { control groups, respectively. } \\
\text { Statistical significance } \\
\text { between the music and control } \\
\text { groups (p<0.001). Decreases } \\
\text { in heart rate (music group - } \\
5.01 \pm 0.79 \text {; control group - } \\
3.76 \pm 0.63 \text { ), systolic blood } \\
\text { pressure (music group }-7.72 \pm \\
1.16 \text {; control group }-12.89 \pm \\
1.16 \text { ) and diastolic blood } \\
\text { pressure (music group }-4.26 \pm \\
0.87 \text {; control group }-4.23 \pm \\
0.78 \text { ) were seen in both groups } \\
\text { from baseline. }\end{array}$ & $\begin{array}{l}\text { No blinding } \\
\text { utilized. }\end{array}$ & $\begin{array}{l}\text { Future studies to } \\
\text { include blood levels } \\
\text { of various outcomes } \\
\text { as well as urine } \\
\text { levels, according to } \\
\text { the authors. }\end{array}$ \\
\hline
\end{tabular}




\section{Appendix B-10}

Palmer, J. B. et al. (2015). Effects of music therapy on anesthesia requirements and anxiety in women undergoing ambulatory breast surgery for cancer diagnosis and treatment: a randomized controlled trial. Journal of Clinical Oncology,33(28), 3162-3168. doi:10.1200/jco.2014.59.6049

\begin{tabular}{|c|c|c|c|}
\hline Purpose & Findings & $\begin{array}{l}\text { Limitations } \\
\text { to the study }\end{array}$ & $\begin{array}{l}\text { Suggestions or } \\
\text { interventions to } \\
\text { improve }\end{array}$ \\
\hline $\begin{array}{l}\text { To investigate the } \\
\text { effect of live and } \\
\text { recorded music } \\
\text { therapy on } \\
\text { anesthesia } \\
\text { requirements, } \\
\text { anxiety levels, } \\
\text { recovery time, and } \\
\text { patient satisfaction } \\
\text { in women } \\
\text { experiencing } \\
\text { surgery for } \\
\text { diagnosis or } \\
\text { treatment of breast } \\
\text { cancer. }\end{array}$ & $\begin{array}{l}\text { Statistically significance defined } \\
\text { as p<0.025. } \\
\text { Measured using Global Anxiety- } \\
\text { Visual Analog Scale (GA-VAS) } \\
\text { scores, patient satisfaction, } \\
\text { amount of Propofol required to } \\
\text { reach a BIS of 70, vital signs and } \\
\text { time to discharge readiness. } \\
\text { Results included: } \\
\text { Amount of Propofol needed to } \\
\text { reach a BIS of } 70 \text { showed that } \\
\text { neither of the music groups } \\
\text { differed from the usual care } \\
\text { group (p=0.17). Patient } \\
\text { satisfaction showed a high level } \\
\text { overall with no difference } \\
\text { between music groups and usual } \\
\text { care or between recorded and } \\
\text { live music groups independently. } \\
\text { The live music and recorded } \\
\text { music groups showed a decrease } \\
\text { in anxiety and both differed } \\
\text { significantly from the control } \\
\text { group (-30.9 } \pm 36.3 \text { and -26.8 } \pm \\
29.3 ; p<0.001 \text { ). The live and } \\
\text { recorded music groups did not } \\
\text { differ in terms of GA-VAS } \\
\text { scores (p=0.39). } \\
\text { According to the scatter plot } \\
\text { created to look at changes of the } \\
\text { GA-VAS scores showed that } \\
\text { reductions in scores were seen } \\
\text { when the baseline score was } \\
\text { high, as opposed to low. Slopes } \\
\text { of regressions of change in } \\
\text { scores versus pretherapy GA- } \\
\text { VAS scores were significantly } \\
\text { less than zero for the live music } \\
\text { and recorded music groups } \\
\text { (p<0.001), but not for the usual }\end{array}$ & $\begin{array}{l}\text { Nurses were } \\
\text { not blinded. }\end{array}$ & $\begin{array}{l}\text { Need for further } \\
\text { studies regarding } \\
\text { therapeutic value of } \\
\text { music therapy, } \\
\text { specifically in the } \\
\text { perioperative setting, } \\
\text { according to the } \\
\text { authors. }\end{array}$ \\
\hline
\end{tabular}


care group $(\mathrm{p}=0.10)$. Estimated slopes for LM (-0.492, RM ($0.448)$ and UC (-0.0138). The slopes of the live and recorded music groups did not differ, but they both differed from the usual care group $(\mathrm{p} \leq 0.002)$, with data as shown above. Time to discharge readiness did not differ between either music group and the control group. However, shorter discharge times were noted for the live music group compared to the recorded music group (difference in 12 minutes; $\mathrm{CI}=$ 22.5 to $-2.2 ; \mathrm{p}=0.018$ ). 
Appendix C

Cross Table Analysis

\begin{tabular}{|c|c|}
\hline Author & Arslan, S. et al. (2008). \\
\hline Key Findings & $\begin{array}{l}\text {-Decrease in anxiety score average in the experimental group compared } \\
\text { to the control group using patient selected music. } \\
\text {-Mean score before therapy were } 39.59 \text { and after therapy were } 33.68 \text { for } \\
\text { the experimental group. } \\
\text {-Mean scores for the control group before therapy were } 42.25 \text { and after } \\
\text { therapy } 44.43 \text {. }\end{array}$ \\
\hline Recommendations & $\begin{array}{l}\text { Larger sample size. } \\
\text { Limitation: } \\
\text {-Study only performed on male patients undergoing urologic surgery. }\end{array}$ \\
\hline Author & Dong, Y. \& Li, Y. (2012). \\
\hline Key Findings & $\begin{array}{l}\text {-Showed that music can reduce preoperative anxiety, especially in } \\
\text { cesarean delivery, and it can augment effects of anesthesia and maintain } \\
\text { hemodynamic stability. } \\
\text {-The mean SAS score was significantly less than before procedure } \\
\text { started in study group and unchanged for control group. } \\
\text {-When groups were compared (study and control) the mean changes in } \\
\text { SAS and HRV values were greater than control group. } \\
\text {-6 hours after surgery, the mean VAS score was significantly lower in } \\
\text { the study group compared to the control group. } \\
\text {-The mean LF and LF/HF values were significantly lower and mean HF } \\
\text { significantly higher after music therapy ( }<0.05 \text { for all). }\end{array}$ \\
\hline Recommendations & $\begin{array}{l}\text {-The authors suggested including the evaluation of intraoperative and } \\
\text { postoperative differences. } \\
\text {-Authors suggested future studies to combine music intervention with } \\
\text { other nonpharmacologic methods considered apt to decrease } \\
\text { sympathetic and increase parasympathetic nervous system activity. } \\
\text {-Results not generalizable to areas outside of women undergoing } \\
\text { cesarean delivery. } \\
\text { Limitation: anesthetic drugs influence HRV values. }\end{array}$ \\
\hline Author & 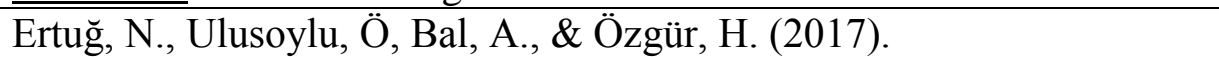 \\
\hline Key Findings & $\begin{array}{l}\text {-Results showed that nature sounds and relaxation exercises were found } \\
\text { to reduce preoperative anxiety in the intervention groups compared to } \\
\text { the control group in patients receiving general anesthesia. } \\
\text { - VAS scores after the 30-minute intervention were lower in nature } \\
\text { sounds groups and relaxation exercises group than the control group. } \\
\text {-SAI scores 30-minutes after intervention were lower in both the nature } \\
\text { sounds and relaxation groups, but no statistically significant. } \\
\text {-A strong and positive relationship between VAS and SAI scores was } \\
\text { found according to Pearson correlation analysis. }\end{array}$ \\
\hline
\end{tabular}




\begin{tabular}{|c|c|}
\hline Recommendations & $\begin{array}{l}\text {-The authors suggested conducting multiple sessions to compare results. } \\
\text {-Suggested using a more objective tool to measure anxiety levels. } \\
\text { Limitations: } \\
\text { - Not blinded. } \\
\text { - Intervention lasted for only one session. } \\
\text { - Interaction between participant and relative for } 30 \text { minutes in } \\
\text { between measurements. }\end{array}$ \\
\hline Author & Ghetti, C. M. (2013). \\
\hline Key Findings & $\begin{array}{l}\text {-Showed that music therapy with emotional-approach coping group led } \\
\text { to improved positive affect states and the EAC group and control group } \\
\text { did not. } \\
\text {-All three groups showed a significant decrease in negative affect. -The } \\
\text { MT/EAC group showed a statistically significant increase in systolic } \\
\text { blood pressure, but not clinically significance as this may be due to } \\
\text { active engagement in the activity of music making. } \\
\text { - MT/EAC group had shorter procedure lengths and least amount of } \\
\text { benzodiazepines required, but not statistically significant. }\end{array}$ \\
\hline Recommendations & $\begin{array}{l}\text {-Larger sample size. } \\
\text {-Longer treatment times. } \\
\text {-Inclusion of inpatient and outpatient populations to enhance } \\
\text { generalizability. } \\
\text { Limitations: } \\
\qquad \quad \text { Small sample size } \\
\text { - High rate of rejection of participants. }\end{array}$ \\
\hline Author & Kovac, M. (2014). \\
\hline Key Findings & $\begin{array}{l}\text {-No consensus on whether provider-selected music or patient-selected } \\
\text { music is more beneficial. } \\
\text {-Music interventions both passive and active, influence patients } \\
\text { physiologically (vital signs) and emotionally (i.e. anxiety). }\end{array}$ \\
\hline Recommendations & $\begin{array}{l}\text { Logistical problems: } \\
\text {-No standardization across studies. } \\
\text {-Preferred music not offered by researchers. } \\
\text {-Difficulty with headphones. }\end{array}$ \\
\hline Author & Kushnir, J. et al. (2012). \\
\hline Key Findings & $\begin{array}{l}\text {-Women who listened to music before cesarean section showed increase } \\
\text { in positive emotions, decrease in negative emotions and perceived threat } \\
\text { of the situation compared to the control group, who experienced } \\
\text { decrease in positive emotions and increase in perceived threat. } \\
\text {-SBP, DBP and RR were noted to be lower in experimental compared to } \\
\text { the control group. } \\
\text {-Experimental group: SBP lower compared to baseline at the } 40 \text { minute } \\
\text { mark of listening to music. } \\
\text {-Control group: DBP and RR were higher after } 40 \text { minutes compared to } \\
\text { baseline. }\end{array}$ \\
\hline
\end{tabular}




\begin{tabular}{|c|c|}
\hline Recommendations & $\begin{array}{l}\text {-Future studies to investigate effectiveness of selecting music has an } \\
\text { effect on anxiety and whether different types of music have different } \\
\text { influences on stress. } \\
\text {-Use a larger sample size and increase generalizability of results. } \\
\text { Limitations: } \\
\text { - Small sample size. } \\
\text { - No Randomization to researchers. }\end{array}$ \\
\hline Author & Labrague, L. J. \& Mcenroe-Petitte, D. M. (2014). \\
\hline Key Findings & $\begin{array}{l}\text {-Results showed decreases in STAI scores, systolic blood pressure, } \\
\text { diastolic blood pressure and pulse rate for the experimental group. } \\
\text {-Overall, results showed women in the experimental group had lower } \\
\text { STAI scores than the control group. } \\
\text {-Independent t test analyses showed experimental group had lower } \\
\text { STAI scores than the control group. }\end{array}$ \\
\hline Recommendations & $\begin{array}{l}\text {-Authors suggested to conduct a study comparing different types of } \\
\text { music with varied listening duration time to determine extent of which } \\
\text { music would exert maximum benefit in decreasing anxiety. - } \\
\text { Investigating the difference between self-selected music and researcher- } \\
\text { selected music in decreasing anxiety among various patient population } \\
\text { in surgery. } \\
\text { Limitations: } \\
\text { - Nonrandomization of participants. } \\
\text { - Participants from one single hospital facility. }\end{array}$ \\
\hline Author & Lee, K. et al. (2011). \\
\hline Key Findings & $\begin{array}{l}\text {-Results showed the mean anxiety level for the control group was } \\
\text { significantly higher than the headphone and the broadcast group. } \\
\text {-Significant difference noted in high frequency HR variability among } \\
\text { the three groups. } \\
\text {-VAS score showed significant decrease for headphone and broadcast } \\
\text { groups, but not for control group. } \\
\text {-Data shows clear reduction in anxiety through music, but retention of } \\
\text { the effect is unclear. }\end{array}$ \\
\hline Recommendations & $\begin{array}{l}\text {-Future studies examine lasting effects of anxiety on outcomes during } \\
\text { intraoperative and postoperative periods. } \\
\text {-Improve research design and add pretest to determine change. } \\
\text { Limitations: } \\
\text { - } \quad \text { No pretest-posttest comparison. } \\
\text { - Participants unable to choose their favorite music. }\end{array}$ \\
\hline Author & Ni, C. et al. (2011). \\
\hline Key Findings & $\begin{array}{l}\text {-Significant decreases in STAI scores from baseline were seen in both } \\
\text { groups, however the mean STAI score was significantly lower in the } \\
\text { music group compared to control. } \\
\text {-Decreases in heart rate, systolic blood pressure and diastolic blood } \\
\text { pressure were seen in both groups from baseline. }\end{array}$ \\
\hline Recommendations & $\begin{array}{l}\text {-Future studies to include blood levels of various outcomes as well as } \\
\text { urine levels, according to the authors. }\end{array}$ \\
\hline
\end{tabular}




\begin{tabular}{|c|c|}
\hline & $\begin{array}{l}\text { Limitation: } \\
\text { • No blinding utilized. } \\
\text { - Results not generalizable beyond day surgery setting }\end{array}$ \\
\hline Author & Palmer, J. B., et al. (2015). \\
\hline Key Findings & $\begin{array}{l}\text {-Results showed that patient satisfaction overall was high. } \\
\text {-Both music groups showed a decrease in anxiety and both differed } \\
\text { significantly from the control group. } \\
\text {-There was no difference observed in GA-VAS scores between the } \\
\text { music groups. } \\
\text {-Shorter discharge times were observed for the live music group when } \\
\text { compared to the recorded music group (difference in } 12 \text { minutes). }\end{array}$ \\
\hline Recommendations & $\begin{array}{l}\text {-Need for further studies regarding therapeutic value of music therapy, } \\
\text { specifically in the perioperative setting, according to the authors. } \\
\text { Limitations: } \\
\text { - Nurses were not blinded. } \\
\text { - Not generalizable to areas outside of women undergoing breast } \\
\text { surgery. }\end{array}$ \\
\hline
\end{tabular}

